\author{
UNIVERSIDADE DE SÃO PAULO \\ FACULDADE DE FILOSOFIA, LETRAS E CIÊNCIAS HUMANAS \\ DEPARTAMENTO DE CIÊNCIA POLÍTICA \\ PROGRAMA DE PÓS-GRADUAÇÃO EM CIÊNCIA POLÍTICA
}

DANILO DE PADUA CENTURIONE

COOPERAÇÃO E CONTROLE: O PAPEL DO LEGISLATIVO EM 20 ESTADOS DA FEDERAÇÃO NA LEGISLATURA 2007-2010.

SÃO PAULO 


\section{COOPERAÇÃO E CONTROLE: O PAPEL DO LEGISLATIVO EM 20 ESTADOS DA FEDERAÇÃO NA LEGISLATURA 2007-2010.}

Dissertação apresentada ao Programa de Pós-Graduação de Ciência Política, do Departamento de Ciência Política da Faculdade de Filosofia, Letras e Ciências Humanas da Universidade de São Paulo, para obtenção do título de Mestre em Ciência Política.

Orientador: Prof. Dr. José Álvaro Moisés

São Paulo

2012 


\section{AGRADECIMENTOS}

Em primeiro lugar, gostaria de agradecer todo o apoio institucional que foi fundamental para a realização deste trabalho. Ao Departamento de Ciência Política da USP, representado pelos seus funcionários e professores, sustentáculos deste trabalho. Agradeço o apoio financeiro de órgãos como: Fapesp, CNPq, Fundação Konrad Adenauer e Instituto Ethos.

Aos colegas do NUPPS, pela convivência e discussões sempre pertinentes, ao professor Bruno Speck, pelo incentivo e apoio à pesquisa. No âmbito do Departamento de Ciência Política, meus agradecimentos vão para todos as professores que tiveram influência direta em minha formação como cientista político. Agradeço à professora Eunice Ostrensky, que me orientou em minha primeira iniciação científica e me ensinou a respeitar o significado de palavras e conceitos. Agradeço aos professores Paolo Ricci e Cláudio Couto, fundamentais no desenvolvimento e conclusão deste trabalho.

Durante todo o período de minha formação acadêmica, desde o primeiro ano de graduação nas ciências sociais, tive a privilégio de conviver, diariamente, com dois grandes amigos: Estevão e Lucas, com os quais dividi minha paixão pela ciência política.

Quero agradecer especialmente ao meu orientador, professor José Álvaro Moisés, com quem aprendi muito mais do que o estritamente acadêmico. Foi quem inspirou o tema e ensinou o papel e a responsabilidade do trabalho intelectual. Sua capacidade de enxergar mais longe e erudição os coloca entre os mais respeitados intelectuais do país.

Agradeço, sobretudo, às pessoas mais importantes durante a empreitada acadêmica, minha amada companheira Débora pelo apoio sentimental e intelectual implacável, e às pessoas que mais admiro e amo: meus pais, Beto e Rosana, razão de ser do meu projeto de vida. Sem os dois este trabalho não existiria. 
"Ao modelar um governo para ser exercido por homens sobre homens, a maior dificuldade é primeiro aparelhar o governo para que controle os governados; o passo seguinte é fazê-lo controlar-se a si mesmo."

James Madison (O Federalista, n. 51). 


\section{RESUMO}

A ciência política brasileira produziu explicações consistentes no que se refere ao funcionamento da democracia pós-1988. Os mecanismos de governabilidade e o processo decisório do sistema político brasileiro encontram-se amplamente discutidos pela literatura sob a rubrica do presidencialismo de coalizão.

No entanto, duas agendas de pesquisa sobre nosso sistema político não foram suficientemente testadas, quais sejam: o estudo sobre as relações Executivo-Legislativo nas unidades subnacionais e os mecanismos de checks and balances em nossa democracia. $\mathrm{O}$ objetivo desta dissertação é analisar o ponto de toque ou mesmo a junção entre estas duas agendas: a dimensão de fiscalização e o controle nas unidades subnacionais brasileiras. Para isso, o desenho de pesquisa é composto pelo balanço do estado da arte das respectivas literaturas relevantes, juntamente à análise dos dados de 20 Estados da Federação Brasileira, na legislatura 2007-2010. 


\begin{abstract}
The Brazilian political science produced consistent explanations about the functioning of democracy in the post-1988 period. The mechanisms of governability and decision-making of the Brazilian political system are widely discussed in the literature under the rubric of coalition presidentialism.

However, two research agendas on our political system have not been sufficiently tested, namely: the study of the Executive-Legislative relations in subnational units and mechanisms of checks and balances in our democracy. The goal of this dissertation is to analyze the touch point or even the junction between these two frameworks: the dimension of supervision and control in the Brazilian subnational units. To accomplish these objectives, the research design consists in the review of the relevant literature, along with the analysis of data from 20 states of the Brazilian Federation - from 2007 to 2010.
\end{abstract}




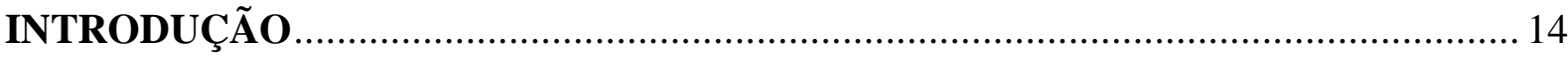

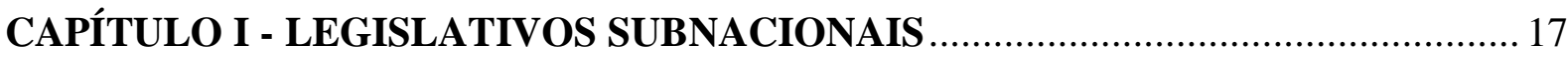

CAPÍTULO II - O CONCEITO DE ACCOUNTABILITY ……........................................ 24

CAPÍTULO III - DESENHO DE PESQUISA (OBJETIVOS, HIPÓTESES,

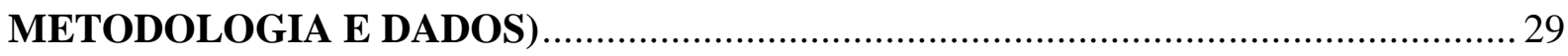

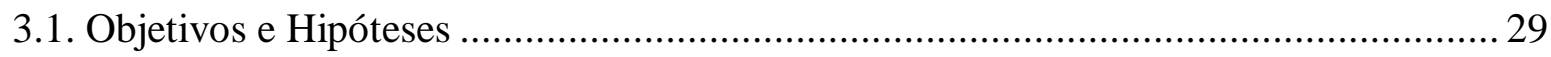

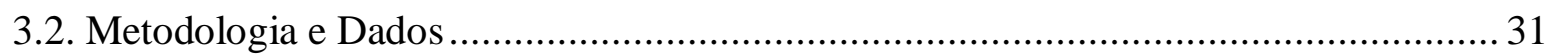

\section{CAPÍTULO IV - COALIZÕES GOVERNISTAS E AS COMISSÕES}

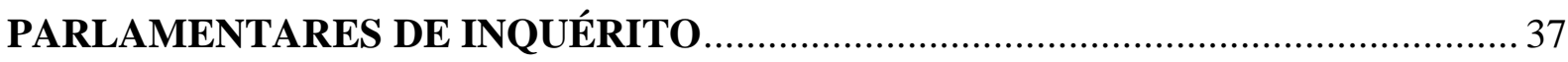

4.1. Coalizões Governistas em 20 Estados Brasileiros........................................................ 37

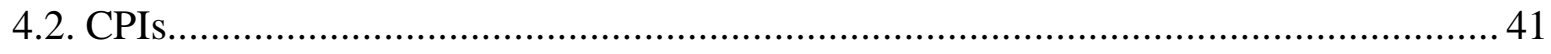

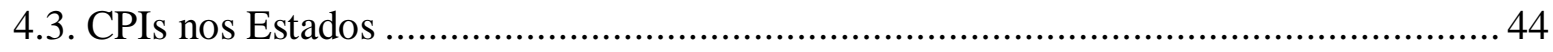

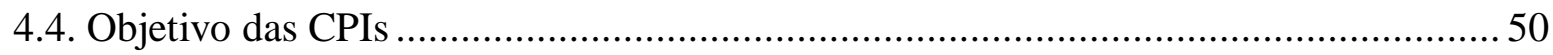

4.5. Cargos-Chave (Presidência e Relatoria) sob a Lógica Governo x Oposição .................. 53

4.6. Desempenho das CPIs: Análise dos Relatórios Finais ...............................................58

4.7. Comparando a CPI nos Diferentes Níveis Governamentais........................................ 63

CAPÍTULO V - ESTUDO DE CASOS: ANÁLISE DE DEZ RELATÓRIOS FINAIS

DAS CPIS NAS ASSEMBLEIAS LEGISLATIVAS ................................................. 70

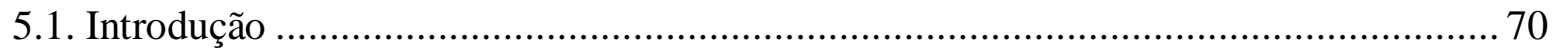

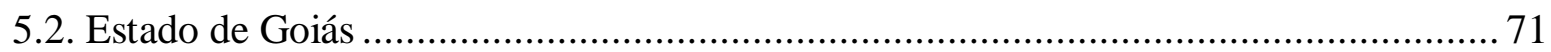

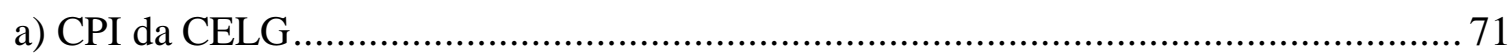

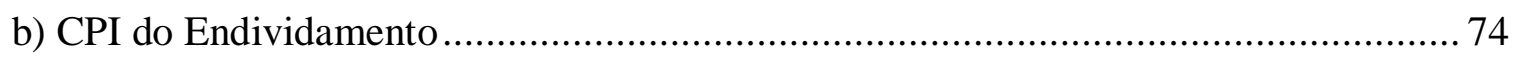

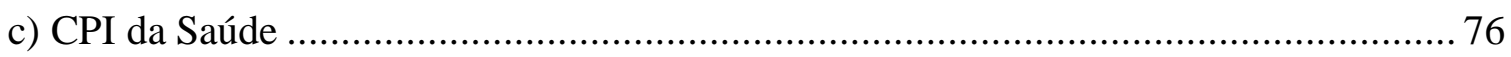

5.3. Estado de São Paulo............................................................................................ 78

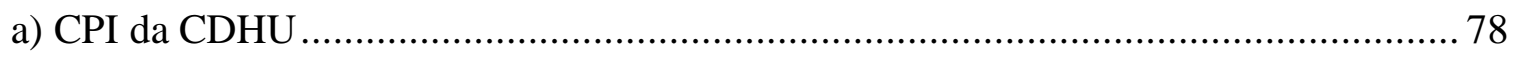

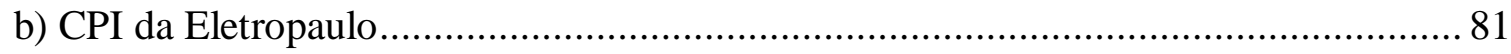

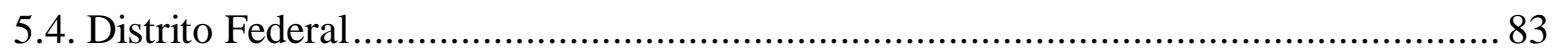

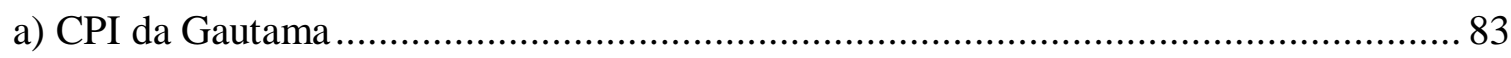

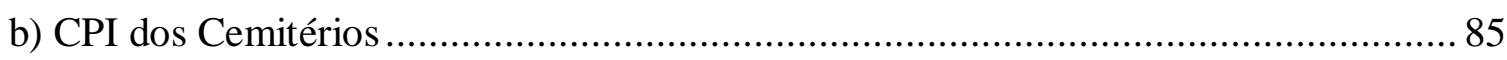




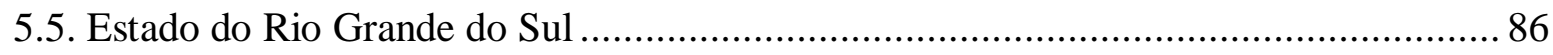

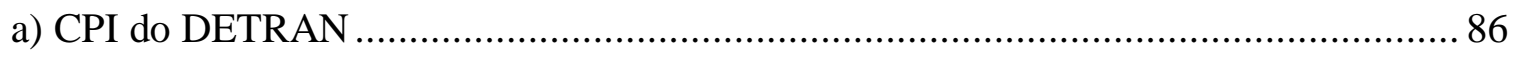

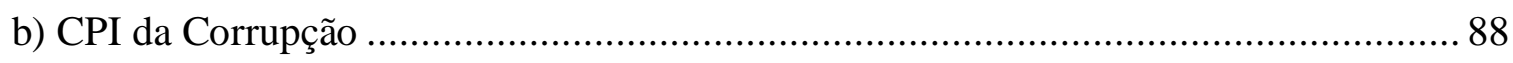

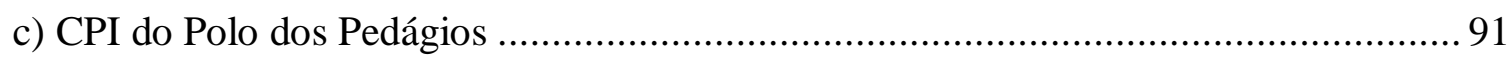

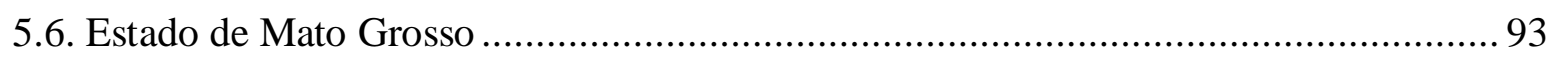

a) CPI da Secretaria do Estado de Meio Ambiente (SEMA) ........................................ 93

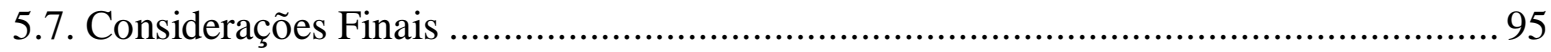

CONCLUSÃO 


\section{ÍNDICE DE QUADROS}

Quadro 1. Variáveis do Bando de dado 1 - Relações Executivo/Legislativo

Quadro 2. Variáveis Bando de Dados 2 - CPIs nas Assembleias Legislativas (Dimensão 1)

Quadro 3. Variáveis do Banco de Dados 3 - CPIs nas Assembleias Legislativas (Dimensão 2)

Quadro 4. Variáveis do Bando de Dados 4 - CPIs nas Assembleias Legislativas (Dimensão 3)

Quadro 5. Desenho Institucional das CPIs nas Assembleias Legislativas.

Quadro 6. Poderes Legislativos dos Governadores

Quadro 7. Classificação do Poder Legislativo dos Governadores

Quadro 8. Comparação entre os diferentes desenhos institucionais: Assembleias Estaduais e Congresso Nacional

Quadro 9. CPIs com objetivo de Investigar o Governo Estadual.................................. 70

Quadro 10. Composição e distribuição dos cargos da CPI da Celg................................ 71

Quadro 11. Requerimentos apresentados na CPI da Celg........................................ 73

Quadro 12. Composição e distribuição dos cargos na CPI do Endividamento............... 75

Quadro 13. Composição e distribuição dos cargos da CPI da Saúde............................ 77

Quadro 14. Composição e distribuição dos cargos da CPI da CDHU............................. 79

Quadro 15. Requerimentos apresentados na CPI da CDHU...................................... 80

Quadro 16. Composição e distribuição dos cargos da CPI da Eletropaulo...................... 81

Quadro 17. Parecer dos Deputados Estaduais sobre Relatório Final da CPI da

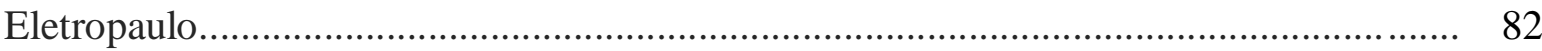

Quadro 18. Composição e Distribuição dos Cargos da CPI da Gautama......................... 84 
Quadro 19. Composição e distribuição dos cargos da CPI dos Cemitérios..................... 85

Quadro 20. Composição e distribuição dos cargos da CPI do Detran............................ 87

Quadro 21. Composição e distribuição dos cargos na CPI da Corrupção...................... 89

Quadro 22. Composição e distribuição dos cargos na CPI do Polo dos Pedágios........... 92

Quadro 23. Composição e distribuição dos cargos na CPI da SEMA............................. 93 


\section{ÍNDICE DE TABELAS}

Tabela 1. Coalizão governista em vinte Assembleias Legislativas, em três momentos distintos na Legislatura 2007-2010

Tabela 2. Presença da base do governo na Mesa Diretora na legislatura 2007-2010 40

Tabela 3. Distribuição do Total de CPIs por Estados 46

Tabela 4. Objetivo das CPIs em 20 Assembleias Estaduais na Legislatura 20072010 .

Tabela 5. Porcentagem de CPIs que fiscalizam o Executivo Estadual

Tabela 6. Cargos-Chave sob a lógica Governo x Oposição, em 20 Assembleias na Legislatura 2007-2010

Tabela 7. Cargos-Chave das CPIs sob a lógica Governo x Oposição, por Estado na Legislatura 2007-2010

Tabela 8. Distribuição dos Cargos-Chave nas CPIs com objetivo de fiscalizar o Executivo

Tabela 9. Distribuição dos Cargos-Chave nas CPIs com objetivo de fiscalizar o Executivo, desagregado por estado

Tabela 10. Classificação do Conteúdo dos Relatórios Finais das CPIs. (Recomendações)

Tabela 11. Classificação do Conteúdo dos Relatórios Finais das CPIs. (Indiciamento e Projetos de Lei)

Tabela 12. Classificação do Conteúdo dos Relatórios Finais das CPIs. (Acionamento de Instituições de Controle)

Tabela 13. Conclusão dos Relatórios Finais das CPIs nos Legislativos Estaduais e Federal 66 


\section{ÍNDICE DE SIGLAS}

AGERGS Agência Estadual de Regulação dos Serviços Públicos Delegados

ALERJ Assembleia Legislativa do Rio de Janeiro

ALESP Assembleia Legislativa de São Paulo

CELG Companhia Energética de Goiás

CDHU Companhia de Desenvolvimento Habitacional e Urbano

CGU Controladoria Geral da União

CODEPLAN Companhia de Planejamento do Distrito Federal

CPI Comissão Parlamentar de Inquérito

DAERS Departamento Autônomo de Estradas e Rodagens

DEM Democratas

DETRAN Departamento Estadual de Trânsito

FHC Fernando Henrique Cardoso

FIPE Fundação Instituto de Pesquisas Econômicas

FKA Fundação Konrad Adenauer

IBAMA Instituto Brasileiro do Meio Ambiente e dos Recursos Naturais Renováveis

INVESTIGOV Investiga o Governo Estadual

MP Ministério Público

N Numero de Casos

NUPPS Núcleo de Pesquisa de Políticas Públicas da Universidade de São Paulo

PC do B Partido Comunista do Brasil

PDT Partido Democrático Trabalhista

PF Polícia Federal

P.L Projeto de Lei

PMDB Partido do Movimento Democrático Brasileiro

PMN Partido da Mobilização

PP Partido Progressista

PR Partido da República

PRP Partido Republicano Progressista 


$\begin{array}{ll}\text { PSB } & \text { Partido Socialista Brasileiro } \\ \text { PSC } & \text { Partido Social Cristão } \\ \text { PSDB } & \text { Partido da Social Democracia Brasileira } \\ \text { PT } & \text { Partido dos Trabalhadores } \\ \text { PTB } & \text { Partido Trabalhista Brasileiro } \\ \text { PTdoB } & \text { Partido Trabalhista do Brasil } \\ \text { PV } & \text { Partido Verde } \\ \text { SEMA } & \text { Secretaria Estadual de Meio Ambiente } \\ \text { SIOPS } & \text { Sistema de Informações sobre Orçamentos Públicos em Saúde } \\ \text { TCE } & \text { Tribunal de Contas Estadual } \\ \text { TCU } & \text { Tribunal de Contas da União }\end{array}$




\section{INTRODUÇÃO}

A produção no que diz respeito à democracia brasileira é vasta e recobre diversas dimensões e diferentes abordagens analíticas. Alguns analistas adotaram linha crítica e negativista em relação à nossa democracia e, segundo eles (MAINWARRING et al., 2001), certas escolhas institucionais teriam impacto negativo sobre a estabilidade do regime. Tal abordagem credita, centralmente, ao multipartidarismo adotado e à representação proporcional a responsabilidade pela instabilidade do regime.

Um segundo grupo de analistas, fortemente representado por Figueiredo e Limongi (1999) apresentou teses contrárias ao argumento da instabilidade e demonstrou, empiricamente, que as regras internas do Legislativo, bem como seu regimento interno, neutralizam os efeitos do multipartidarismo e da representação proporcional que poderiam levar à instabilidade do regime.

Nosso ponto de partida dá como resolvidos os dilemas sobre a estabilidade do regime e considera, altamente satisfatória e suficientemente comprovada, a explicação dada pelo segundo grupo sobre a funcionalidade de nosso sistema político e a estabilidade de nossa democracia. Nosso objetivo, no entanto, é jogar luz sobre uma dimensão negligenciada em boa parte das análises pregressas: os mecanismos de accountability e checks and balances entre os Poderes Executivo e Legislativo. Nesse sentido, compartilhamos da análise de Moisés (2011), segundo a qual, as abordagens consolidadas sobre a nossa democracia não se propuseram a identificar as implicações da supremacia do Executivo para a dimensão de fiscalização e controle do Poder Legislativo, restando, assim, uma agenda de pesquisa não suficientemente explorada e/ou testada do ponto de vista empírico.

A mencionada supremacia do Executivo dá-se, tanto pelas suas prerrogativas constitucionais (medidas provisórias, leis delegadas, etc.) quanto pela própria dinâmica interna do Poder Legislativo. O controle que o Executivo possui, através de suas prerrogativas constitucionais, somado ao controle que exerce sobre o processo legislativo através das lideranças partidárias e do colégio de líderes, pode guardar para o Poder Legislativo condições que constrangem o princípio de checks and balances entre esses Poderes.

A agenda acerca da accountability horizontal, de suas ligações com a estrutura institucional e da influência sobre o comportamento dos atores, é resumida na seguinte 
afirmação de Moisés (2011, p. 8): "diante de incentivos institucionais tão eficazes para que os parlamentares acompanhem a posição da maioria governativa, é duvidoso que reste espaço, quando isso seja necessário, para a crítica e/ou a correção de posições do executivo". Constatação similar à de Madison (2003, p. 420), em $O$ federalista: "se uma maioria se constituir em torno de um interesse comum, os direitos da minoria correrão perigo".

Portanto, o objetivo dessa agenda não é se constituir como uma agenda negativa de pesquisa, cujo objetivo primeiro é negar e se contrapor aos reais ganhos analíticos trazidos pelas análises seminais e suficientemente comprovadas da área (acerca da estabilidade e governabilidade), mas sim, trazer, para a análise da democracia brasileira, a dimensão de fiscalização e controle. Além disso, assim como a falta de governabilidade no Brasil foi dada de barato durante décadas, poucas pesquisas sistemáticas e empíricas foram feitas para investigar a situação dos mecanismos de accountability horizontal, em nosso sistema político.

É pressuposto normativo dessa abordagem que o Poder Legislativo deve possuir grau de independência e autonomia suficiente para executar suas prerrogativas constitucionais, condição sine qua non para a accountability. Contudo, a força do Poder Executivo, através de suas prerrogativas e outros recursos que concentra, facilita o controle sobre a coalizão governista no interior do Poder Legislativo, trazendo sérios desdobramentos para outras dimensões da democracia, como argumenta Figueiredo (2002, p. 692):

À medida que aumenta a capacidade de controle do Executivo sobre a coalizão governista, diminui a do Congresso para fiscalizar o Executivo. O poder de estabelecer a agenda e controlar o processo legislativo reduz tanto as iniciativas de fiscalização dos parlamentares, quanto suas chances de sucesso.

O trecho descrito por Figueiredo (2002) caracteriza o que Diamond e Morlino (2005) definiram como trade-off:, ao incrementarem uma dimensão da democracia na definição do desenho institucional, os atores fazem-no em detrimento de outra dimensão. No caso retratado pela autora, a dimensão de governabilidade é privilegiada em detrimento da dimensão de accountability e checks and balances ${ }^{1}$. Nesse contexto, esta dissertação parte do pressuposto de que nosso sistema político deve ser estabelecido sob mecanismos institucionais promotores

\footnotetext{
${ }^{1}$ Outros analistas acompanham esse raciocínio: “A concentração de atribuições e recursos nas mãos dos líderes de coalizão no interior do Poder Legislativo, embora seja conducente à maior estabilidade política, afeta negativamente a operação dos atributos da accountability e da representatividade por violar o princípio da igualdade política entre os representantes.” (ANASTASIA et al., 2010, p. 72).
} 
do princípio democrático angular de checks and balances e que as eleições, ou seja, a dimensão vertical da accountability, não são suficientes para garantir o controle dos governantes: "elections are not the only democratic mechanism that may induce governments to act in a representatitive manner." (MANIN; PRZEWORSKY; STROKES, 1997, p. 11), sendo prerrogativa dos Legislativos fiscalizar as contas e os atos do Poder Executivo.

Uma das vertentes teóricas que emolduram a presente dissertação é a de Diamond e Morlino (2005), no livro Assessing the quality of democracy. Os autores desenvolveram oito dimensões (entre elas, a accountability) que, conjuntamente, compõem o sistema que deve definir o que é uma "democracia de qualidade". No tocante à democracia brasileira e a todos os estados da federação estudados nesta dissertação, eles cumprem os requisitos mínimos da definição procedimental da democracia: competição institucionalizada pelo poder, por meio de eleições periódicas e competitivas. Não obstante, a dimensão de fiscalização e controle é fundamental para o funcionamento da democracia e, a despeito disso, parece consenso, tanto no meio acadêmico quanto na opinião pública, a debilidade dos mecanismos de accountability e checks and balances.

Em suma, o conceito de qualidade da democracia reforça e compartilha a mesma motivação normativa desta dissertação em relação à deficiência de funcionamento e pendência em dimensões pontuais das democracias contemporâneas, como, por exemplo, os mecanismos republicanos de responsabilização e accountability. No entanto, o tratamento analítico deste estudo não recorre apenas aos pressupostos normativos propostos pela abordagem da qualidade da democracia, mas também à utilização dos instrumentais analíticos da escolha racional para explicar o comportamento dos atores, com foco nas instituições responsáveis pelos mecanismos de checks and balances nos estados brasileiros (Assembleias estaduais, Comissões Parlamentares de Inquérito - CPIs). Além disso, a possível influência de seus procedimentos e arranjos institucionais/constitucionais será fortemente incorporada à análise.

A maioria dos estudos sobre os Legislativos estaduais brasileiros (SANTOS et al., 2001; CERVI, 2009; ANASTASIA; CASTRO; NUNES, 2009; CARREIRÃO; RICCI; TOMIO, 2010) concentrou-se na produção das leis, votações nominais, prerrogativas constitucionais e, sobretudo, teste e apontamento dos limites da tese desenvolvida por Abrúcio (1998). Por sua vez, a presente dissertação tem como objetivo analisar a dimensão de fiscalização e controle dos deputados estaduais sobre os governadores brasileiros. 


\section{CAPÍTULO I - LEGISLATIVOS SUBNACIONAIS}

A obra que inspirou a presente dissertação e o respectivo desenho de pesquisa foi o seminal trabalho de Abrúcio (1998), Os barões da federação, na qual o autor deslocou o olhar da ciência política para as unidades subnacionais, buscando entender o poder dos governadores na pós-democratização e a relação desses com os demais poderes do estado. Analisando o período entre 1991 e 1994, em 15 estados, Abrúcio (1998) cunhou a expressão ultrapresidencialismo estadual para definir as relações Executivo-Legislativo nos estados. Segundo Abrúcio (1998), o ultrapresidencialismo estadual vigorava nos estados da federação devido ao forte domínio do Executivo/governador sobre o processo político e os órgãos de fiscalização.

Seu objetivo de pesquisa acerca das relações Executivo-Legislativo nos estados partiu da constatação de que a Constituição de 1988 havia alterado a correlação de forças entre os poderes, tornando o Poder Legislativo Federal responsável pelas decisões terminativas da política brasileira, aumentando, inclusive, seu poder de fiscalização. Porém, segundo Abrúcio (1998), o mesmo não havia ocorrido na esfera estadual, na qual predominava a hipertrofia do Executivo. Tal processo ocorreria pela eliminação da possibilidade de outros poderes o controlarem destruindo o princípio fundamental da democracia de checks and balances. Nesse contexto, as Assembleias Legislativas seriam controladas pelo governo, através da formação de maiorias governistas sólidas, para garantir a aprovação quase total dos projetos do seu interesse e, principalmente, para deter seu poder de fiscalização.

Para Couto (1998), nem mesmo o conteúdo das políticas passa pelo crivo dos deputados, que abdicam de suas capacidades legislativas em troca da transferência de recursos do Executivo, configurando o que autor chama de coalizão fisiológica de governo. Segundo Andrade (1998), na formação da coalizão fisiológica de governo, os deputados abstêm-se de utilizar suas prerrogativas legais de fiscalização e controle em troca da distribuição de cargos aos partidos da coalizão majoritária, constituindo uma forma bastante segura para garantir o apoio parlamentar ao chefe do Executivo.

No entanto, o fundamental para Abrúcio (1998) foi indicar e identificar a natureza dessa maioria governista, ou seja, jogar luz sobre a formação dessa maioria e os seus 
desdobramentos capazes de tornar o Executivo hipertrofiado. Foi o que o autor - precedido por Couto (1991) - chamou de pacto homologatório: através de "moedas" (recursos, emendas e cargos de primeiro e segundo escalão no governo), o Executivo constrói maioria legislativa, disposta à aprovação de todos os projetos legislativos de interesse do governador e à abdicação de seus poderes de fiscalização e controle, "apenas homologando decisões dos governos estaduais." (ABRUCIO, 1998, p. 113). Dessa forma, o Executivo controla a maioria governista, que, em troca de benesses individuais, opta pela prática do apoio total e irrestrito às iniciativas do governador; portanto, os Executivos estaduais, além de construírem maioria, agem de modo a pôr fim ao "princípio de independência entre os Poderes, neutralizando qualquer reação do Legislativo as suas políticas.” (ABRUCIO, 1998, p. 114)².

Seu diagnóstico é contundente, e podemos derivar de seus apontamentos um quadro de total debilidade institucional, no qual as Assembleias Legislativas são efetivas somente como canal de comunicação com o governador para a prospecção de recursos financeiros e políticos a fim de que, em alguns casos, o deputado estadual alcance a reeleição e, na maioria deles, a candidatura a prefeito ou deputado federal, uma vez que cooperar com o Executivo seria a única saída racional para atingir tais objetivos. Portanto, o cenário desenhado pelos achados de Abrúcio (1998) não aponta para o fenômeno de abuso de poder do Executivo sobre as prerrogativas do Legislativo e, sim, para a delegação total de poder e responsabilidades do Legislativo para o Executivo. Dessa forma, como afirma Andrade (1998, p. 28), "o Legislativo abriu mão dos seus poderes de veto, obstrução e controle, bem como de qualquer responsabilidade real de formulação de políticas".

Analisando a Assembleia Legislativa de São Paulo, entre 1991 e 1994, Abrúcio (1998) demonstrou o total domínio do governador Fleury sobre o Legislativo estadual, que desempenhou papel meramente homologatório e abdicou de sua prerrogativa legislativa. Com isso, Fleury

Conseguiu montar o 'tripé da impunidade' isto é, neutralizou os mecanismos fiscalizadores da Assembléia Legislativa, do Tribunal de Contas do Estado e do Ministério Público [...] o governador Fleury possuía mecanismos para neutralizar qualquer investigação mais a fundo de possíveis irregularidades cometidas em sua gestão. (ABRUCIO, 1998, p. 158).

\footnotetext{
${ }^{2}$ Em doze dos quinze estados analisados por Abrúcio (1998), entre 1991 e 1994, o governador possuía sólida maioria.
} 
Segundo Costa e Oliveira (1998), o expediente utilizado pelo governador para barrar ou constranger CPIs era pressionar os deputados com cargos nas Secretarias de Estado ou premiar outros parlamentares dissidentes com cargos em estatais.

Para os fins a que se destina esta dissertação, vale detalhar os argumentos de Abrúcio (1998) acerca do controle do Executivo sobre os mecanismos que se destinam a fiscalizá-lo: tanto conselheiros do TCE quanto o procurador-geral do Ministério Público (MP) são nomeados pelos governadores; no caso dos TCEs, uma parte é nomeada pela Assembleia. Porém, com o controle que o Executivo possui do Legislativo, na prática, o governador nomeia todos os membros do colegiado. Nesse caso, o Executivo tem prerrogativa legal e força política necessária para nomear quem irá julgar suas contas. O autor enfatiza, ainda, que o resultado desse processo é a formação de colegiados politizados, partidarizados e fortemente vinculados ao governador e seus companheiros de coalizão. Nesse sentido, vale reproduzir a passagem sobre o lobby dos governadores na Constituinte:

Houve um grande lobby das bancadas dos governadores na Constituinte para que a escolha do TCE continuasse politizada, pois somente seriam escolhidos para estes cargos os correligionários mais fieis ao governador. A criação dos Tribunais de Contas compostos por técnicos poderia ser uma forma de quebrar a lógica da política estadual, o que não interessa a elite governante local, ávida por manter a estratégia vitoriosa do governismo. (ABRUCIO, 1998, p.141, grifos nossos).

A politização do TCE e o controle dessa instituição pelo Executivo, segundo Abrúcio (1998), têm outros efeitos na política estadual. Além de neutralizar o poder de fiscalização do órgão para julgar as contas do governador e seus aliados, esse controle gera o efeito contrário para adversários políticos do governador. Nesse caso, prefeitos de partidos de fora da coalizão podem ter suas contas rejeitadas como forma de retaliação política, ou seja, além de afetar a dimensão de fiscalização e controle, a influência do governador nas instituições de fiscalização pode, em última instância, atingir outra dimensão cara à democracia: a competição política, pois, ao influenciar no julgamento de contas de seus rivais políticos, o governador pode produzir danos substantivos no capital político do adversário.

Já na escolha do procurador-geral do MP, o governo escolhe de uma lista tríplice indicada pelo próprio ministério. Nesse caso, o governador inicia o processo de aliança já na 
disputa interna, no MP, apoiando um candidato governista para que, ao aprovar o nome, tenha influência dentro do Ministério Público:

No caso do Ministério Público e Tribunal de Contas, [...] parece ter se tornado desdobramento natural da carreira controlador e controlado passarem de um lado para o outro como se fosse razoável uma autoridade participar de um governo num dia e no outro julgar se esse governo agiu com correção. (FONTES, 1994).

A forte conclusão de Abrúcio (1998) acerca do ultrapresidencialismo estadual brasileiro foi a constatação analítica de uma esfera não republicana nos estados. Para tanto, o autor recorre a Madison para constatar as consequências da total ausência de controles institucionais sobre o governador: "o princípio dos checks and balance é a pedra angular do presidencialismo, dando-lhes as feições republicanas e democráticas. Nos estados brasileiros, a ausência de checks and balance tornou o jogo político intransparente e totalmente dominado pelo governador." (ABRUCIO, 1998, p. 164).

Em 2001, Abrúcio et al. (2001) apresentam texto dando sequência ao debate iniciado em Os barões da federação (1998). Ao analisarem a Assembleia Legislativa de São Paulo, na Legislatura 1995-1998, os autores testaram as hipóteses dos trabalhos pregressos de Abrúcio, no contexto de crise do federalismo estadual, com a diminuição dos poderes do governador nos estados, provocada pelo impacto de medidas do governo Fernando Henrique Cardoso (FHC), com o objetivo de normatizar a relação entre estados e União, na área fiscal. A renegociação das dívidas estaduais e a intervenção da União nos bancos dos estados tiveram o efeito de matizar o poderio dos governadores (MAINWARING, 1997; COUTO; ABRÚCIO, 2003). No que tange à força do Executivo no processo decisório, os achados de Abrúcio et al. (2001) reforçam os argumentos anteriores: no orçamento, todas as peças enviadas pelo Executivo foram aprovadas com tranquilidade, fruto do controle do Executivo sobre o processo legislativo. Além disso, o Executivo, da mesma forma como ocorreu na legislatura anterior analisada, neutralizou os poderes fiscalizatórios do Legislativo ao cooptar deputados e manter o controle sobre o TCE e o MP. Portanto, o cenário analisado traduzia o típico ultrapresidencialismo estadual encontrado por Abrúcio (1998) analisando São Paulo, nos anos de 1991 a 1994, sendo uma das características da Assembleia o "escasso recurso às comissões parlamentares de inquérito e as pífias conclusões das poucas que escaparam ao controle da presidência da Mesa.” (ABRUCIO et al., 2001, p. 245). 
Por sua vez, a coletânea organizada por Fabiano Santo (2001), O poder legislativo nos estados: diversidade e convergência, teve como objetivo revisitar os pressupostos e hipóteses dos trabalhos seminais de Fernando Abrúcio, tendo sido produzidas análises de uma legislatura (1995-1998) em 6 estados da federação, testando a hipótese central do ultrapresidencialismo estadual. As conclusões desse trabalho inserem um ponto de interrogação sobre os argumentos propostos por Abrúcio. No caso de São Paulo e Espírito Santo, os autores identificaram o que se denominou ultrapresidencialismo estadual, em que o Legislativo está subordinado ao poder do governador, através das trocas fisiológicas que envolvem o pacto homologatório. Já nos casos de Minas Gerais e Rio de Janeiro, os autores apontam para a existência de Poderes Legislativos proativos, que contam com certa autonomia, estabelecendo equilíbrio entre os dois poderes.

Analisando o caso da Assembleia Legislativa de Minas Gerais, Anastásia (2001) lista as inovações institucionais ocorridas no período da análise, visto que a casa legislativa passou por processo estrutural de reformulação, que partiu da constatação de pesquisas de opinião pública de que a Casa não contava com a confiança dos cidadãos do estado. Entre os mecanismos implantados nesse processo, o autor dá destaque para os canais de comunicação e participação direta da sociedade dentro da Assembleia, tornando a casa mais responsiva perante a população; além da assessoria técnica qualificada para subsidiar a tomada de decisão ou posicionamento do parlamentar em relação a questões específicas. Já na análise das relações Executivo/Legislativo e de toda a produção legislativa, concluiu que, em Minas Gerais, o Executivo não tem preponderância legislativa; além disso, à revelia do que foi encontrado em outros estados, destaca a alta produção legislativa oriunda do Poder Legislativo.

Já no caso do Espírito Santo, Domingues (2001) encontrou, como resultado de pesquisa, características muito similares aos trabalhos de Abrúcio, uma vez que a Assembleia Legislativa do Espírito Santo mostrou-se incapaz de influir na produção legislativa, ocupando papel de subserviência em relação ao governador. Segundo essa análise, vigorou, no estado, o ultrapresidencialismo estadual, com base no pacto homologatório entre Legislativo e Executivo, com espaço mínimo para a atuação da oposição e para a independência dos poderes.

Por fim, analisando a Assembleia Legislativa do Rio de Janeiro, Santos (2001) apresenta cenário diametralmente oposto ao apresentado por autores que analisaram outros 
estados. O autor aponta "a existência de uma experiência sui generis. A autonomia e a capacidade de produzir leis na Alerj não têm paralelo entre os casos examinados.” (p. 290). Segundo o autor, a produção legislativa da Assembleia é relevante e bastante extensa, possuindo uma agenda própria (temática social) e distinta do Executivo (temas de natureza econômica).

Em Sob a ótica da delegação: governadores e assembléias no Brasil pós-1989, Pereira (2001) parte de uma pergunta de pesquisa central: os deputados são cooptados ou delegam autoridade para os governadores? Segundo o autor, o conceito de delegação não guarda o mesmo juízo de valor negativo de termos como clientelismo, físiologismo etc. $\mathrm{O}$ argumento desenvolvido pelo autor defende que a delegação de poderes ocorre do Executivo para as lideranças internas do Legislativo. No contexto legislativo, os cargos mais importantes responsáveis pela formação da agenda são: Mesa Diretora, líderes da bancada, presidência e relatoria de comissões permanentes e temporárias. Segundo Pereira (2001), os parlamentares ocupantes desses cargos seriam agentes responsáveis por tomar decisões favoráveis ao Executivo Estadual.

Entre os textos mais recentes que tiveram como objetivo aprofundar a análise empírica e testar as hipóteses de Abrúcio et al., destaca-se Instituições de decisões: estudo comparativo do processo legislativo nas assembléias estaduais (RICCI; TOMIO, 2010), cujo objetivo central é acompanhar a formação e a aprovação dos projetos de lei nos Legislativos estaduais. Os achados apontam na direção contrária às conclusões da literatura pregressa, sobretudo Abrúcio (1998), em Os barões da federação.

A despeito de não negarem a força dos governadores, Ricci e Tomio (2010) não compartilham do diagnóstico de debilidade institucional dos Legislativos estaduais ou da existência de deputados estaduais "engessados" pela estrutura de um pacto homologatório. A proatividade dos Legislativos e o protagonismo dos deputados estaduais nos outcomes legislativos, em alguns estados, foram as conclusões derivadas pelos autores através da análise da tramitação dos projetos de lei nas Assembleias do país. Já na análise empírica de dados, como taxa de sucesso, vetos e dominância, os autores encontraram um único estado (Sergipe) com as características ultrapresidenciais descritas por Abrúcio; nos demais, encontraram quadros variados, que, se não enfraquecem, põem um ponto de interrogação sobre as hipóteses de Abrúcio e seus seguidores. 
Ricci e Tomio (2010) diferem, centralmente, do argumento proposto por Abrúcio, ao enfatizarem o que explica a força dos governadores nos estados. Para os autores, a debilidade das Assembleias Legislativas e os pactos políticos de natureza clientelista não são variáveis explicativas centrais para o fenômeno, mas sim as prerrogativas legislativas constitucionais em poder dos governadores. Porém, para avançar dessa constatação para inferências analíticas acerca do funcionamento das relações Executivo/Legislativo, nos estados, os autores apontam para a necessidade do entendimento das "dinâmicas político partidárias internas a cada estado" (p. 12). A abordagem dos autores traz do estado de arte da literatura do presidencialismo de coalizão o olhar analítico sobre os outcomes legislativos, sob o prisma que vai além da contraposição entre o Poder Legislativo e o Executivo e privilegia a dimensão de governo x oposição (maiorias e minorias).

No mais recente artigo sobre a temática, Ricci e Tomio (2012) aprofundam a análise com base em extensa série temporal (1951 - 2010). Analisando os recursos institucionais conferidos ao poder Executivo e Legislativo estadual, previstos na Constituição Federal, os autores oferecem explicação consistente acerca do sucesso dos governadores na aprovação propostas legislativas. A Constituição de 1988 dá à União competência exclusiva e abrangente para vinte e nove temas da administração pública, restando aos estados espaço muito limitado para legislar, sendo que a produção de norma jurídica relevante ficaria guardada apenas a União. Para os autores, esse é, centralmente, o aspecto do federalismo brasileiro que explica a força dos governadores em aprovar suas propostas, ou seja, a própria configuração constitucional limita as propostas dos governadores a temáticas pouco polêmicas e de caráter burocrático-administrativo. Por sua natureza, essas propostas independem do apoio maciço ao governador na Assembleia, para serem aprovadas. Portanto, o fator explicativo para força dos governadores, segundo os autores, é a própria configuração constitucional e não o tamanho da coalizão formada. 


\section{CAPÍTULO II - O CONCEITO DE ACCOUNTABILITY}

Após as transições democráticas, parte da ciência política se voltou para os tipos de diferentes desenhos institucionais das democracias latino-americanas. Na esteira desses estudos, o tema da accountability surgiu como uma fonte de concepções ligadas a outros assuntos, como representatividade, império da lei, responsabilização, qualidade da democracia, entre outros. É a partir desse ponto que as diferenciações começaram a ocorrer e as fronteiras do conceito foram estabelecidas. $\mathrm{O}$ termo vem sendo largamente utilizado nos trabalhos contemporâneos de ciência política; além disso, o tratamento das chamadas dimensões verticais e horizontais da accountability está crescendo, fortemente, no debate acadêmico sobre a boa governança, uma vez que

Esse fenômeno traduz um processo mais amplo pelo qual a responsabilização adquiriu grande centralidade não só no léxico das Ciências Sociais, mas também na mídia. É significativo que, no final de 2004, no site de buscas Google, o número de referências à responsabilização (accountability) tenha alcançado a notável marca de 115 milhões de registros. (MELO, 2007, p. 12).

Na literatura especializada, o conceito desdobrou-se, basicamente, em três definições distintas de accountability: societal, vertical e horizontal.

$\mathrm{Na}$ análise de Smulovitz e Peruzzotti (2000), entende-se que não só atores institucionais podem ou devem desempenhar função de fiscalização e controle do poder público, mas também associações de cidadãos ou usuários de serviços públicos, organizações da sociedade civil e a mídia podem incumbir-se da tarefa de zelar pela administração pública, configurando a esfera do que a literatura especializada tem chamado de accountability societal.

A forma vertical da accountability ocorre por meio de eleições livres e justas, nas quais os cidadãos podem punir ou premiar um mandatário, votando a seu favor ou contra ele ou, ainda, nos candidatos que apoia nas eleições seguintes. A definição de O’Donnell (1998) para a accountability eleitoral é:

Eleições, reivindicações sociais que possam ser normalmente proferidas, sem que se corra o risco de coerção, e cobertura regular 
pela mídia ao menos das mais visíveis dessas reivindicações e de atos supostamente ilícitos de autoridades públicas são dimensões do que chamo accountability vertical. (p. 29).

Deixando de lado, neste trabalho, os vários estudos e propostas de melhoria na dimensão vertical da accountability, ou seja, o controle socioeleitoral dos poderes, no desenho de pesquisa desta dissertação, interessa-nos, de modo particular, a extensão legal da accountability horizontal, visto que essas instituições responsáveis pela prestação de contas assumem papel nodal nas democracias representativas. Nesse sentido, o fortalecimento efetivo dos mecanismos de controle e fiscalização é uma das condições para o melhoramento da qualidade institucional das novas democracias e, segundo Figueiredo (2002, p. 689), "analistas políticos parecem ter chegado a um consenso sobre as deficiências dos mecanismos de accountability horizontal nos sistemas presidencialistas da América Latina."

O autor mais citado na bibliografia referente à chamada accountability horizontal é O’Donnell, sendo, em diversos textos, dado como referência como aquele que propôs a definição seminal de accountability horizontal. Até então, o espaço para o debate desse tipo de mecanismo democrático era restrito, tanto academicamente quanto na esfera políticoinstitucional de alguns governos da América Latina, fato que despertou o interesse de O’Donnell pelo tema: “Como mostram alguns governos latino-americanos, mesmo os mais consolidados apresentam accountability horizontal fraca ou ineficiente." (O’DONNELL, 1998, p. 28).

Para ele, a definição de accountability horizontal é:

A existência de agências estatais que têm o direito e o poder legal e que estão de fato dispostas e capacitadas para realizar ações, que vão desde a supervisão de rotina a sanções legais ou até o impeachment contra ações ou emissões de outros agentes ou agências do Estado que possam ser qualificadas como defeituosas. (O’DONNELL, 1998, p. 40).

É importante destacar que, conforme esse autor, para que essa accountability seja eficiente, é necessário que existam agências estatais autorizadas e dispostas a fiscalizar, controlar e corrigir ações ilícitas envolvendo agentes públicos de outras agências estatais, principalmente nos casos em que atores de posições elevadas estão envolvidos. Para tanto, a instituição responsável pela efetivação da accountability horizontal não deve ser isolada de 
outras agências, mas fazer parte de uma rede de agências, que tem, como sua ação final, a tomada de decisões nos tribunais, "pois é ali que o sistema constitucional se fecha mediante as decisões últimas." (O’DONNELL, 1998, p. 43).

Já para Diamond e Morlino (2005), que desenvolveram o conceito de qualidade da democracia, a accountability horizontal corresponde à presença de instituições especificamente desenhadas para a fiscalização e o controle, como, por exemplo, as comissões legislativas, instituições de auditoria etc. Ainda segundo os autores, a condição vital para o sucesso da accountability horizontal e dos mecanismos de checks and balances é a garantia da independência da instituição em relação ao governo.

De acordo com Taylor e Buraneli (2007), para atingir melhor instrumental analítico no estudo da accountability horizontal, no Brasil, é preciso decompor o processo de prestação de contas em partes e fazer a análise das instituições responsáveis segundo a seguinte divisão: fiscalização, (foco no monitoramento ex ante, com o objetivo de alertar sobre maus comportamentos, antes que eles progridam), investigação (objetivo ex post de verificar a profundidade e o conteúdo do ato ilegal cometido pelo ator público) e sanção (responsabilização dos atores por seus atos). O segundo passo é jogar luz sobre a necessária interação entre esses três componentes distintos, porém, complementares, tendo em vista que a ausência de cooperação e/ou harmonia interinstitucional pode enfraquecer o mecanismo de responsabilização e controle. Portanto, segundo esses autores, o conceito de accountability deve conter, no seu interior, um pressuposto fundamental: a complexidade de dimensões, subdivididas em diversas partes, comportam atores e procedimentos, instituições e padrões de ação distintos. Em síntese, esse é o conceito defendido por Mainwarring et al. (2003) de web of accountability, segundo o qual, a qualidade da interação entre as distintas instituições influencia o resultado final do processo de prestação de contas.

Para Laurence Whitehead (2000), os problemas de accountability, na América Latina, não estão relacionados à criação de novas instituições ou à modificação das existentes. A solução estaria em fortalecer os mecanismos de feedback através do eleitorado e do mercado, fazendo com que as instituições existentes sejam pressionadas para melhorar sua amplitude, coordenação e efetividade. O autor aponta para a necessidade de readequar as instituições que existem de modo que elas fiquem mais próximas de seus desenhos teóricos iniciais. A accountability política, formalmente, é a autoridade de fiscalização e sanção que é depositada em certos atores designados para realizar tal tarefa. O arcabouço legal e 
institucional deve autorizar os atores a cumprirem seu dever de demandar respostas e responsabilizar os funcionários públicos ou a burocracia. Mas, quais seriam esses atores?

Seriam, basicamente, de dois tipos. Em primeiro lugar, temos os oficiais públicos eleitos, que devem respondem aos eleitores; em segundo, as agências estatais, que, formalmente, devem processar e aplicar sanções aos funcionários públicos e burocratas. É desse segundo ponto que se origina a accountability interestatal, ou seja, entre a relação das agências de controle. Os exemplos são variados: comissões legislativas que investigam desvios na administração pública; agências desenhadas especificadamente para monitorar ilegalidades de funcionários públicos; o sistema legal, que dá suporte para as investigações de casos de corrupção; o Congresso, quando inicia inquéritos; e os parlamentares, quando processam autoridades públicas e ministros.

Outro importante foco dessa discussão é a inclusão da capacidade de aplicar sanções, segundo o conceito de accountability. Alguns autores, como Kenney, argumentam que essa relação implica, necessariamente, a capacidade do agente impor sanções para os transgressores; noção não compartilhada por O’Donnell, para quem os mecanismos de accountability se depositam, exclusivamente, na responsabilização, sem necessariamente, implicar a aplicação de sanções. Mainwaring concorda com Kenney ao afirmar que a accountability deve conter o poder de sanção, havendo capacidade de corrigir os desvios redirecionando os casos para o sistema de justiça, o que não quer dizer que tal sistema necessite do poder de sanção direto e legal.

No campo da teoria principal-agente, temos duas correntes de pensamento. A primeira está localizada no argumento de Moreno, Crisp e Shugart (2005), que restringe a accountability a uma relação de principal-agente. Nessa concepção, se o principal puder destituir ou decidir contra a renovação do agente, existiria uma relação de accountability. Diferentemente do que colocam O’Donnel e Kenney ao argumentar que nem todas as relações desse tipo implicam um principal que pode destituir um agente. Esse debate chama a atenção de Mainwaring para um ponto importante: "a relação de poder é diferente quando um principal pode destituir ou decidir contra a renovação de um agente em comparação com um contexto em que essa possibilidade não existe" (p.14). O autor chama a atenção para a limitação do conceito de accountability se tivermos, como foco, somente a relação principalagente. Mesmo não havendo esse tipo de relação, um funcionário público pode, formalmente, responder por suas ações e pode estar sujeito a sanções. 
Para Mainwaring, existe uma relação de accountability quando uma agência pública é, formalmente, responsiva a um outro ator, pertencendo à rede de accountability as instituições de controle e o judiciário, já que estas últimas são as responsáveis pelas sanções e punições. A relação agente-principal seria uma parte das relações de accountability. No caso das comissões de investigação legislativas (ou Comissões Parlamentares de Inquérito, no Brasil), se elas investigam algum desvio do presidente, são também responsáveis por rever as ações dele. Apesar dessa situação não se configurar como uma relação principal-agente, ela se enquadraria em uma relação de accountability, porque o presidente deve responder à comissão.

Dentre tantas questões debatidas, restaria saber quais são os atores que são os agentes de promoção da accountability. Se pensarmos em termos de responsividade e sanções informais, qualquer ator pode ser agente dessa circunstância. Na verdade, devem existir atores formalmente responsáveis por vigiar os ofícios públicos. O problema reside em saber quais são esses atores e é nesse quesito que se encontram as divergências. Para os que advogam pela relação principal-agente, existe a clara exclusão das agências de vigilância e das instituições, que são independentes umas das outras. Uma visão intermediária, como a de Kenney, inclui o judiciário na rede de accountability, mas exclui as instituições de controle, enquanto um olhar mais amplo leva em conta todas essas possíveis situações, como mostra O’Donnel, que inclui as instituições de controle, com a ressalva de que o ator, sob investigação, deve ter cometido alguma infração prevista legalmente. 


\section{CAPÍTULO III - DESENHO DE PESQUISA (OBJETIVOS, HIPÓTESES, METODOLOGIA E DADOS)}

\subsection{Objetivos e Hipóteses}

O objetivo desta dissertação é o estudo das relações Executivo-Legislativo em 20 estados brasileiros, com concentração na dimensão de fiscalização e controle do Poder Executivo, exercida pela Assembleia Legislativa, levando em conta na análise: prerrogativas constitucionais, arcabouços institucionais e incentivos gerados por essas estruturas.

As análises contidas na coletânea organizada por Santos (2001) e o artigo de Ricci e Tomio (2010) trouxeram ricas evidências para o debate de que, do ponto de vista da produção de políticas públicas (analisando as votações nominais) e prerrogativas constitucionais, existem variações entre os estados, sendo que, em alguns deles, o argumento de Abrúcio (1998) pode ser contestado, uma vez que os achados indicam Legislativos institucionalizados (aparato técnico especializado), proativos e responsáveis por parcelas importantes de produção de matéria relevante, como, por exemplo, as Assembleias de Minas Gerais e do Rio de Janeiro, na Legislatura 1995-1998. No entanto, a análise de Abrúcio, em Os barões da federação e em seus artigos posteriores, trata dos desdobramentos da supremacia do Executivo sobre o Legislativo, da natureza do pacto homologatório entre os poderes e, centralmente, das consequências desse processo para a dimensão de checks and balances e, em última instância, da independência e autonomia dos poderes.

Apesar de ter apresentado argumentos contundentes e eloquentes, Abrúcio (1998) não testou parte das hipóteses em seu trabalho seminal, principalmente as relacionadas ao déficit de fiscalização do Legislativo em relação ao Executivo. Além disso, a tese do poderio dos governadores, no plano estadual, assim como seus desdobramentos para o sistema de freios e contrapesos, foi pouco analisada pela literatura. $\mathrm{O}$ poder de agenda e as prerrogativas que permitem ao governador coordenar o processo legislativo, através da disciplina das lideranças parlamentares, produzem consequências para os mecanismos de checks and balances. 
Nesse contexto, pretendemos verificar se, em um sistema em que a governabilidade assenta-se sobre as prerrogativas constitucionais do Executivo e a montagem de coalizões majoritárias, resta espaço para que o Legislativo exerça sua prerrogativa de fiscalização e controle ou se a força do Executivo e seu controle sobre as lideranças partidárias engessam, por definição, a possibilidade de o Legislativo controlar o Poder Executivo. Em outras palavras, temos como objetivo testar a existência de trade-off entre cooperação e controle e, para além disso, identificar resultados que expliquem os diferentes desempenhos das Assembleias Legislativas na dimensão de fiscalização e controle.

Para tanto, definimos três hipóteses concorrentes quanto às CPIs: amplitude da coalizão governista, desenho institucional e prerrogativas constitucionais.

\section{- Hipótese 1: Amplitude da coalizão governista}

O domínio exercido pelo governador sobre o Legislativo estadual, através das coalizões majoritárias, determina a proatividade dos deputados estaduais no que tange à dimensão de fiscalização e controle (CPIs), sendo que estados com coalizões governistas minoritárias ou de maioria simples terão Legislativos mais ativos na fiscalização ao Executivo, via instalação de CPIs. Portanto, o tamanho da coalizão determina a variação de instalação de CPIs nos estados;

\section{- Hipótese 2: Desenho institucional intralegislativo}

Quanto maiores os constrangimentos institucionais contra a instalação de CPIs contidos no regimento interno, menor a ocorrência de CPIs nos estados. Da mesma forma, quanto menos restritivas forem as regras para instalação das CPIs, maior a ocorrência delas na Assembleia Legislativa. Em suma, o desenho institucional explica a variação da ocorrência de CPIs nos estados;

\section{- Hipótese 3: Prerrogativas constitucionais do Poder Executivo}

Em alguns estados brasileiros, o Poder Executivo possui prerrogativas legislativas típicas do presidente, como as medidas provisórias e as leis delegadas. Logo, as variações nas prerrogativas constitucionais dos governadores nos diferentes estados e sua importância, em decorrência do 
impacto sobre as relações Executivo/Legislativo, determinam a variação no número de CPIs;

\subsection{Metodologia e Dados}

Nos últimos anos, tem crescido o número de pesquisadores engajados em especializar-se em política comparada, porém, a despeito da proliferação desses trabalhos, a atenção dada ao método comparativo nas unidades subnacionais não teve o mesmo crescimento (SNYDER, 2009). Na verdade, as análises sobre as unidades subnacionais permitem aumentar a quantidade de casos e minimizar o problema clássico apontado por Coliier (1993) e Liphart (1970), entre outros, de muitas variáveis e um pequeno número de casos. Segundo Przeworski e Teune (1970), um alto grau de generalização deve ser o principal objetivo das ciências sociais.

O seminal trabalho de Abrúcio (1998), Os barões da federação, utilizou o mixed method, ao combinar um N médio e o estudo de caso sobre o estado de São Paulo. Decorrente disso construiu argumentos generalizáveis sobre sua teoria e uma análise mais aprofundada e complexa de um caso (São Paulo). Já a coletânea coordenada por Santos (2001) baseou-se no estudo de caso de 6 estados, lidando com especificidades da dinâmica microinstitucional dos casos selecionados. Por sua vez, o trabalho de Tomio e Ricci (2010) privilegiou a análise estatística com $\mathrm{N}$ grande.

$\mathrm{Na}$ presente dissertação, optamos por um $\mathrm{N}$ grande e abrangente no desenho de pesquisa, visando a construir um banco de dados com o maior número possível de casos, com o objetivo de atingir inferências generalizantes, mesmo que parcimoniosas, em comparação aos estudos de caso ou estudo com $\mathrm{N}$ pequeno. Esse desenho de pesquisa permitirá a análise de material empírico sistematizado para o uso da perspectiva comparada; além disso, o recorte temporal (2007-2010) possibilitará manter constante a influência de variáveis de natureza conjuntural. Nesse sentido, Figueiredo (2001), ao incentivar pesquisas comparadas em relação aos estados brasileiros, ressalta a possibilidade de controlar variáveis gerais, devido à condição sui generis do país: "o número de estados e a diversidade dos sistemas políticos estaduais no Brasil nos oferecem condições excepcionais." (p. 11). 
Para a análise dos mecanismos de fiscalização e controle nos estados brasileiros, foram construídos 5 bancos de dados distintos, com 20 estados de nossa federação, correspondentes à Legislatura 2007-2010. Os estados que fazem parte da amostra são: Acre, Amazonas, Amapá, Bahia, Ceará, Espírito Santo, Goiás, Maranhão, Minas Gerais, Mato Grosso, Mato Grosso do Sul, Pernambuco, Rio de Janeiro, Rio Grande do Norte, Rondônia, Rio Grande do Sul, Sergipe, São Paulo e Tocantins e o Distrito Federal.

A pesquisa tinha como objetivo inicial coletar informações para o máximo possível de estados do país, portanto, todos os estados com os quais conseguimos estabelecer comunicação e coletar os dados estão contidos na amostra, não tendo sido utilizado nenhum outro filtro na seleção dos casos aqui estudados. De fora do estudo, ficaram somente as unidades subnacionais com as quais a comunicação e cooperação no envio dos dados não foram realizadas pelas instituições quando da solicitação de informações, reiterada via ofício, correio eletrônico e telefone.

O primeiro banco de dados teve suas nove variáveis designadas com o objetivo de verificar a validade da hipótese difundida do governismo nos estados brasileiros. Além disso, medimos, entre outras coisas, a progressão da base do governo no decorrer do mandato e a presença de membros da coalizão majoritária na Mesa Diretora. Os resultados do banco serviram de variável independente na análise do estudo das CPIs e dos diferentes padrões encontrados nas Assembleias, visto que, com eles, pudemos olhar as CPIs dentro da lógica sugerida por Ricci e Tomio (2010): "há indícios claros de que nas assembleias estaduais algumas questões devem ser compreendidas à luz da clara contraposição entre governo e oposição.” (p. 24). 
Quadro 1. Variáveis do Bando de Dados 1 - Relações Executivo Legislativo

\begin{tabular}{|c|c|}
\hline \multicolumn{2}{|c|}{ BASE GOVERNISTA NOS ESTADOS } \\
\hline $\begin{array}{c}\text { NOME DA } \\
\text { VARIÁ VEL }\end{array}$ & DESCRIÇÃo \\
\hline EstFed & Estado da Federação \\
\hline NomePart & Nome dos Partidos com Representação na Casa Legislativa \\
\hline NumDepPar & Numero de Deputados por Partido \\
\hline CoalGov & Lista dos Partidos da Coalizão Governista \\
\hline MigrPart & Migrações Partidárias ao longo da Legislatura \\
\hline BasGov2006 (1) & Base Governista na Assembleia \\
\hline BasGov2006 (2) & Base Governista na Assembléia Pós Resultado Eleitoral - Formação do Governo \\
\hline BasGov2009 & Base Governista na Assembléia no final do Governo \\
\hline BasGovMes & Presença de Membros da Base na Mesa Diretora \\
\hline
\end{tabular}

Fonte: Elaboração do Autor

O segundo banco de dados teve como objetivo verificar a normatização dos mecanismos das CPIs, nas Assembleias Legislativas, com base nas diretrizes apontadas no Regimento Interno delas, a fim de averiguar variabilidade de regras institucionais nas Casas e os incentivos ou constrangimentos contidos nas regras regimentais quanto à instalação de CPIs.

\section{Quadro 2. Variáveis Banco de Dados 2 - CPIs nas Assembleias Legislativas} (Dimensão 1)

\begin{tabular}{|c|c|}
\hline \multicolumn{2}{|c|}{ BASE GOVERNISTA NOS ESTADOS } \\
\hline NOME DA & DESCRIÇÃ̃o \\
VARIÁ VEL & Estado da Federação \\
\hline EstFed & Numero de Deputados necessários para Assinar Requerimento de CPI \\
\hline DepAss & Limitação Regimental do numero de CPIs em andamento (Numero) \\
\hline LimReg & Ampliação no numero Regimental de CPIs (Procedimento) \\
\hline AmpReg & \\
\hline
\end{tabular}

Fonte: Elaboração do Autor

O terceiro banco de dados catalogou todas as CPIs existentes nas 20 Assembleias, no período de 2007 a 2010, segundo diversas variáveis, como os nomes e partidos dos postos- 
chave (autoria, presidência e relatoria); trabalho semelhante foi feito por Figueiredo (2001) em relação às CPIs no Congresso Nacional. A inovação do presente estudo foi a inclusão da variável InvestGov para identificar as CPIs, com o objetivo de fiscalizar o Executivo estadual e suas Secretarias, distinguindo essas CPIs de outras com temas mais generalistas.

\section{Quadro 3. Variáveis do Banco de Dados 3 - CPIs nas Assembleias Legislativas}

\section{(Dimensão 2)}

\begin{tabular}{|c|c|}
\hline \multicolumn{2}{|c|}{ BASE GOVERNISTA NOS ESTADOS } \\
\hline $\begin{array}{c}\text { NOME DA } \\
\text { VARIÁ VEL }\end{array}$ & DESCRIÇÃ \\
\hline NCPI & Nome da CPI \\
\hline ObjCPI & Objetivo CPI \\
\hline Ano & Ano em que a CPI foi instalada \\
\hline AutCPI & Autor da CPI \\
\hline PartAu & Partido do Autor \\
\hline BaseGov1 & Indica se o Partido do Autor faz parte da Base do Governador \\
\hline PresCPI & Presidente da CPI \\
\hline PartPres & Partido do Presidente \\
\hline BaseGov2 & Indica se o Partido do Presidente faz parte da Base do Governador \\
\hline RelCPI & Relator da CPI \\
\hline PartRel & Partido do Relator \\
\hline BaseGov3 & Indica se o Partido do Relator faz parte da Base do Governo \\
\hline Inst & Data de Instalação da CPI \\
\hline Encer & Data de Encerramento da CPI \\
\hline ConTrab & Indica se houve conclusão dos trabalhos \\
\hline InvestGov & Indica se a CPI tinha por objetivo investigar o Governo Estadual (Poder Executivo) \\
\hline Fon
\end{tabular}

Fonte: Elaboração do Autor

O quarto banco de dados teve como motivação a percepção da ausência de indicadores capazes de verificar o desempenho das CPIs. Assim, variáveis de análise de desempenho foram operacionalizadas, tendo em vista as prerrogativas constitucionais das comissões temporárias. Foram objeto de análise todos os relatórios finais das CPIs concluídas (e com relatório disponível), nos 20 estados da federação, entre 2007 e 2010. 
Quadro 4. Variáveis do Bando de Dados 4 - CPIs nas Assembleias Legislativas

(Dimensão 3)

\begin{tabular}{|c|c|}
\hline \multicolumn{2}{|c|}{ BASE GOVERNISTA NOS ESTADOS } \\
\hline $\begin{array}{c}\text { NOME DA } \\
\text { VARIÁ VEL }\end{array}$ & DESCRIÇÃo \\
\hline NCPI & Nome da CPI \\
\hline PartRel & Partido do Relator \\
\hline BaseGov & Indica se o Partido do Relator faz parte da Base do Governador \\
\hline AgGov & Indica se a CPI tinha por objetivo Investigar ou não o Governo Estadual (Poder Executivo) \\
\hline RecLeg & Indica Recomendação ao Legislativo \\
\hline RecJud & Indicação Recomendação ao Judiciário \\
\hline RecExe & Indica Recomendação ao Executivo \\
\hline EncMP & Indica Encaminhamento ao Ministério Público \\
\hline EncPF & Indica Encaminhamento a Policia Federal \\
\hline EncTCE & Indica Encaminhamento ao Tribunal de Contas Estadual \\
\hline Ind & Indica Indiciamento \\
\hline PropAltL & Indica Proposta ou alteração de Projeto de Lei \\
\hline
\end{tabular}

Fonte: Elaboração do Autor

Todos os dados correspondentes aos quatro bancos desta dissertação tiveram a mesma forma de coleta. Em um primeiro momento, foram enviados ofícios para as Assembleias Legislativas (destinados aos presidentes em exercício), tendo ocorrido uma taxa de retorno em torno de $30 \%$ da amostra. Uma segunda rodada de comunicação e coleta ocorreu através de pedidos de informação, via correio eletrônico, para as Diretorias Legislativas e a terceira rodada teve sua solicitação realizada diretamente por telefone pelo pesquisador. Ao final do processo de coleta, que durou 6 meses, foram obtidas informações satisfatórias e suficientemente confiáveis sobre 20 estados da federação.

Para testar a hipótese (1) acerca do impacto da amplitude da coalizão governista sobre a dimensão de fiscalização e controle (CPIs), analisaremos os dados dos bancos (1) Relações Executivo/Legislativo nos estados e (3) CPIs nas Assembleias Legislativas. No teste da hipótese (2) que credita as variações dos desenhos institucionais às diferenças de ocorrência de CPIs nos estados, serão utilizados os bancos (2) desenho institucional e (3) CPIs nas Assembleias Legislativas. Para analisar a viabilidade da hipótese (3), que credita às Constituições Estaduais e às prerrogativas descritas por elas a variação de ocorrência de CPIs 
nos diferentes estados, analisaremos fragmentos das Constituições Estaduais juntamente com a análise do banco (3) CPIs nas Assembleias Legislativas. 


\section{CAPÍTULO IV - COALIZÕES GOVERNISTAS E AS COMISSÕES PARLAMENTARES DE INQUÉRITO}

\subsection{Coalizões Governistas em 20 Estados Brasileiros}

A operacionalização do conceito de coalizão, na presente dissertação, não se pretende exaustiva, pelo contrário, privilegiou-se a definição de um conceito estreito de coalizão, que não dá conta da enormidade de abordagens possíveis. Como definido por Amorim Neto (1994), o termo 'coalizão' pode, entre outras interpretações, indicar, pelo menos, três abordagens: alianças eleitorais, acordos com as bancadas legislativas sobre vários ou um único tema e/ou composição do gabinete do Executivo.

Nesta dissertação, a coalizão é formada pelos partidos, nas Assembleias Legislativas, que apoiam o governador, com informação descrita no Diário Oficial e/ou declaração expressa do presidente da Casa, via resposta de ofício solicitando informações. Ainda, partimos do pressuposto estabelecido por Riker (1962) de que qualquer governo que deseje alcançar sucesso, do ponto de vista da aprovação de suas proposições e cujo Executivo não tem sólida maioria legislativa, terá, invariavelmente, de recorrer às coalizões. Também compartilhamos do diagnóstico que identifica relativa facilidade em montar coalizões pelo Executivo, visto que esse poder "controla uma grande variedade de recursos, tais como crédito, execução de emendas individuais dos parlamentares, concessões de televisão e rádio, licitações etc.” (PEREIRA; MUELLER, 2000, p. 50).

Em Os barões da federação, Abrúcio (1998) apresenta dados que comprovam sua hipótese de prevalência de um padrão governista nas Assembleias Legislativas estaduais na

Legislatura 1991-1994. Dos 15 estados analisados, 13 tinham maioria esmagadora de deputados que apoiavam a coalizão governista. Além disso, o autor identificou dois momentos distintos correlacionados ao tamanho da base do governador:

No ultrapresidencialismo estadual, constatou-se a existência de dois padrões de competição política nos estados: no momento eleitoral vigorava uma disputa multipartidária; no momento governativo, vigorava uma lógica quase monolítica, em que praticamente todos os políticos giravam em torno do governo estadual, e a favor do 
governador, alterando completamente o tradicional adágio político: há governo, sou a favor. (ABRUCIO, 1998, p. 121).

Tendo em vista a necessidade de testar essa hipótese em outro contexto histórico e a necessidade de testar as hipóteses próprias desta dissertação, segue tabela com os dados de 20 estados da federação na Legislatura 2007-2010:

Tabela 1. Coalizão Governista em Vinte Assembleias Legislativas, em Três Momentos Distintos na Legislatura 2007-2010 ${ }^{3}$

\begin{tabular}{|c|c|c|c|c|c|}
\hline$\frac{8}{8}$ & $\begin{array}{c}\text { Primeiro Momento: } \\
\text { Base do Governo - } \\
\text { Resultado Eleitoral } \\
(2006)\end{array}$ & $\begin{array}{c}\text { Poder de } \\
\text { Atração do } \\
\text { Executivo: } \\
\text { Aumento da } \\
\text { Base do } \\
\text { Governo }\end{array}$ & $\begin{array}{c}\text { Segundo Momento: } \\
\text { Base do Governo } \\
\text { Pós Resultado } \\
\text { Eleitoral (2007) }\end{array}$ & $\begin{array}{c}\text { Poder de } \\
\text { Atração do } \\
\text { Executivo: } \\
\text { Aumento da } \\
\text { Base do } \\
\text { Governo }\end{array}$ & $\begin{array}{c}\text { Terceiro Momento: } \\
\text { Base do Governo } \\
(2009)\end{array}$ \\
\hline AC & $58,3 \%$ & $8,3 \%$ & $66,7 \%$ & $4,2 \%$ & $70,8 \%$ \\
\hline AM & $41,7 \%$ & $37,5 \%$ & $79,2 \%$ & $8,3 \%$ & $87,5 \%$ \\
\hline AP & $33,3 \%$ & $41,7 \%$ & $75,0 \%$ & $4,2 \%$ & $79,2 \%$ \\
\hline BA & $33,3 \%$ & $3,2 \%$ & $36,5 \%$ & $4,8 \%$ & $41,3 \%$ \\
\hline CE & $54,3 \%$ & $39,1 \%$ & $93,5 \%$ & $0,0 \%$ & $93,5 \%$ \\
\hline DF & $37,5 \%$ & $41,7 \%$ & $79,2 \%$ & $0,0 \%$ & $79,2 \%$ \\
\hline ES & $36,7 \%$ & $60,0 \%$ & $96,7 \%$ & $0,0 \%$ & $96,7 \%$ \\
\hline GO & $53,7 \%$ & $14,6 \%$ & $68,3 \%$ & $2,4 \%$ & $70,7 \%$ \\
\hline MA & $38,1 \%$ & $-4,8 \%$ & $33,3 \%$ & $14,3 \%$ & $47,6 \%$ \\
\hline MG & $51,9 \%$ & $9,1 \%$ & $61,0 \%$ & $2,6 \%$ & $63,6 \%$ \\
\hline MS & $62,5 \%$ & $20,8 \%$ & $83,3 \%$ & $0,0 \%$ & $83,3 \%$ \\
\hline MT & $66,7 \%$ & $8,3 \%$ & $75,0 \%$ & $4,2 \%$ & $79,2 \%$ \\
\hline PE & $26,5 \%$ & $26,5 \%$ & $53,1 \%$ & $14,3 \%$ & $67,3 \%$ \\
\hline RJ & $47,1 \%$ & $24,3 \%$ & $71,4 \%$ & $4,3 \%$ & $75,7 \%$ \\
\hline RN & $50,0 \%$ & $16,7 \%$ & $66,7 \%$ & $-4,2 \%$ & $62,5 \%$ \\
\hline RO & $29,2 \%$ & $33,3 \%$ & $62,5 \%$ & $0,0 \%$ & $62,5 \%$ \\
\hline RS & $21,8 \%$ & $54,5 \%$ & $76,4 \%$ & $-1,8 \%$ & $74,5 \%$ \\
\hline SE & $28,0 \%$ & $40,0 \%$ & $68,0 \%$ & $4,0 \%$ & $72,0 \%$ \\
\hline SP & $44,7 \%$ & $30,9 \%$ & $75,5 \%$ & $1,1 \%$ & $76,6 \%$ \\
\hline TO & $45,8 \%$ & $33,3 \%$ & $79,2 \%$ & $-8,3 \%$ & $70,8 \%$ \\
\hline
\end{tabular}

Fonte: Elaboração do Autor

\footnotetext{
${ }^{3}$ Faz-se necessário ressaltar que o procedimento de coleta adotado nesta dissertação não permite classificarmos como de "oposição" partidos que não façam parte da coalizão governista. O procedimento metodológico adotado negligenciou as votações nominais, portanto, é possível que partidos que estejam fora da coalizão formal (declarado em Diários Oficiais e pelo presidente da casa em exercício, em resposta ao ofício enviado) votem com o governo em questões pontuais.
} 
A necessidade de compartilhar dos recursos concentrados nas mãos do Executivo torna os legisladores da maioria dos partidos vulneráveis na negociação. Assim, resta, quase que unicamente, ao principal partido da coligação eleitoral derrotada, o papel de oposição. Em recente entrevista, Fernando Limongi (2011) sintetizou esse processo:

Enquanto alguns partidos competem pelo Executivo, os outros disputam migalhas. Eles não têm para onde correr a não ser para o governo. Eles têm que ser pragmáticos. A única chance de conseguirem cadeiras nas eleições seguintes é tendo algum ministério para fazer política pública, que é o que chega na população e nos interesses. Sem acesso a isso, não elege ninguém e desaparece. Esses partidos se seguram nisso. Por isso que eu digo: é barato montar coalizão. Os nanicos não têm poder de barganha nenhum. Fazer oposição é luxo, precisa ser rico para isso.

Verificamos, também, a presença dos membros da bancada governista na Mesa Diretora, haja vista a importância desse órgão na direção e centralização do processo decisório no interior das casas legislativas. A importância da Mesa Diretora para as relações Executivo/Legislativo nos estados e, mesmo, seus desdobramentos para a dimensão de fiscalização e controle são apontados na tese de Clemente (2007, p. 34):

Para que um governador tenha tranqüilidade em aprovar suas propostas e evitar constrangimentos causados por um escrutínio minucioso de seu governo, basta concentrar esforços a cada dois anos para que um fiel aliado seja eleito presidente da Assembléia e, assim, controle o processo legislativo. 
Tabela 2. Presença da Base do Governo na Mesa Diretora na Legislatura 2007-2010

\begin{tabular}{|c|c|}
\hline ESTADO & $\begin{array}{c}\text { Presença da Base do } \\
\text { Governo na Mesa } \\
\text { Dire tora da Assembléia } \\
\text { Legis lativa }\end{array}$ \\
\hline$A C$ & $86,0 \%$ \\
\hline AM & $100,0 \%$ \\
\hline AP & $88,7 \%$ \\
\hline BA & $28,6 \%$ \\
\hline CE & $100,0 \%$ \\
\hline DF & $87,8 \%$ \\
\hline ES & $100,0 \%$ \\
\hline GO & $75,4 \%$ \\
\hline MA & $30,6 \%$ \\
\hline MG & $76,8 \%$ \\
\hline MS & $100,0 \%$ \\
\hline MT & $74,5 \%$ \\
\hline PE & $93,0 \%$ \\
\hline RJ & $82,3 \%$ \\
\hline RN & $92,5 \%$ \\
\hline RO & $86,0 \%$ \\
\hline RS & $64,9 \%$ \\
\hline SE & $100,0 \%$ \\
\hline SP & $77,4 \%$ \\
\hline TO & $80,0 \%$ \\
\hline
\end{tabular}

Fonte: Elaboração do Autor

Em $85 \%$ da amostra de Assembleias Legislativas, a base governista ocupou, pelo menos, $75 \%$ dos cargos da Mesa Diretora das Assembleias. Portanto, o controle da base do governo em relação aos mecanismos de tomada de decisão é muito acentuado. Em estados como Amazonas, Ceara, Sergipe, Mato Grosso do Sul e Espírito Santo, os deputados que apoiam o governador ocupam 100\% dos cargos da Mesa Diretora das ALs. 


\subsection{CPIs}

Existem, pelo menos, quatro mecanismos formais para que o Legislativo, através de suas atribuições constitucionais, fiscalize o Executivo: requerimentos de informação, interpelação parlamentar, requisição de fiscalizações aos TCEs e inquérito parlamentar, através das CPIs. O debate sobre o controle legislativo e o papel das CPIs encontra-se na rubrica de pesquisas sobre accountability, conceito cuja definição seminal em torno da ideia de responsabilização é, frequentemente, atribuída a O’Donnel (1998). Ressalte-se que, em termos da accountability horizontal, as CPIs correspondem ao chamado controle político, ou seja, é a dimensão da prestação de contas e fiscalização, em que os parlamentares se organizam para investigar um fato passível de inquérito e de natureza eminentemente política.

Portanto, esta seção concentra-se nas CPIs, instituições formais que permitem a fiscalização do Executivo pelo Legislativo nas Assembleias Legislativas. Além disso, analisaremos, em perspectiva comparada, o desenho institucional das Casas Legislativas no que tange às CPIs, para testar a hipótese de que diferentes desenhos podem afetar o comportamento dos atores, uma vez que compartilhamos do pensamento de Couto (1998, p. 46) de que "indivíduos racionais agem de acordo com parâmetros que lhes são dados pelo ambiente em que atuam, particularmente o ordenamento institucional."

As 66 CPIs que ocorreram na Legislatura 2007-2010 serão analisadas sob a lógica governo/oposição. Além disso, pretendemos verificar até que ponto as prerrogativas constitucionais da CPI produzem efeitos através da ação ou inação dos atores relevantes, por meio da análise dos relatórios finais, visando a cobrir uma lacuna na literatura em relação à dificuldade de desenhos de pesquisa com o objetivo de mensurar os efeitos da fiscalização (LEMOS, 2006).

Nesse sentido, Santi (2007) destaca que o instrumento mais efetivo para fiscalizar o Executivo é o inquérito parlamentar, pois os poderes de investigação, amplos, somados à natureza política dessas comissões temporárias, garantem resultados expressivos. Ainda segundo o autor, as comissões possuem legitimidade para produzir o efeito necessário apontado por autores da teoria democrática, como O'Donnel, que defendem a necessidade de uma articulação entre as instituições para que a accountability seja efetiva. 
Ainda, Santi (2007) é bastante otimista quanto ao papel constitucionalmente descrito e efetivamente alcançado pelas CPIs, enxergando-as como mecanismo responsável por promover a articulação e ativação da rede de accountability das instituições de controle do país (MP, Polícia Federal - PF, Controladoria Geral da União - CGU, Tribunal de Contas da União - TCU, TCEs), respondendo à grande demanda descrita na literatura especializada do gap entre as instituições e a necessidade de articular essa rede (BURANELLI; TAYLOR, 2007).

Por sua vez, o artigo de Figueiredo (2002), Instituições e política no controle do executivo, foi o primeiro trabalho empírico acerca das CPIs que sistematizou sólida base de dados sobre a temática. Segundo a autora, a configuração institucional deve resguardar a independência dos poderes, ao produzir estrutura de incentivo que motive a fiscalização entre o Poder Executivo e o Legislativo. No entanto, no Brasil, o Poder Executivo conta com dispositivos constitucionais e mecanismos, no próprio regulamento legislativo, para controlar o Poder Legislativo através dos líderes da coalizão (colégio de líderes) e da Mesa Diretora, que disciplinam o comportamento da bancada e permitem o domínio do governo sobre a agenda no processo legislativo, minando a capacidade e independência deste poder.

O aumento da capacidade de controle do chefe do Executivo sobre a coalizão no Legislativo estaria intimamente ligado à correlata diminuição do poder de fiscalização e controle de; além disso, o controle dos líderes sobre suas bancadas tem o poder de constranger comportamentos particularistas, a despeito dos incentivos eleitorais a condutas desse tipo. Para Figueiredo (2002), o próprio arcabouço institucional constrange a atuação particularista dos deputados, dificultando ações desse tipo na produção de legislação e na fiscalização e controle do Executivo. Depreende-se disso que as ações no sentido de reforçar os mecanismos de accountability devem enfrentar os custos da ação coletiva, na busca de quorum suficiente para apoiar a ação.

No caso das CPIs, existem ainda outros pontos de veto e custos embutidos na ação. Por exemplo, após ser proposta, uma CPI pode não ser instalada, visto que os partidos da coalizão, através de seus líderes, podem não indicar o nome dos membros de seus partidos que devem compô-la - constitucionalmente, é prerrogativa do líder indicar o membro partidário que irá compor a CPI. Esse é apenas um dos exemplos dados por Figueiredo (2002) para ilustrar o fato de que o contexto pré e durante as CPIs envolve uma série de dispositivos formais e informais que pode determinar a viabilidade, o sucesso ou o fracasso das comissões. 
Portanto, embora o Poder Legislativo tenha ganhado incrementos no poder de fiscalização pós-Constituição de 1988, a dinâmica institucional impõe altos custos para que uma ação fiscalizatória tenha sucesso.

Através da comparação empírica das CPIs nas democracias de 1946 e pós-1988, Figueiredo (2002) conclui que as variáveis políticas (bem como o tamanho das coalizões e controle partidário) não explicam as variações existentes. Para ela, o sistema fornece várias entradas e possibilidades de iniciar fiscalização, porém o desenho institucional não favorece o sucesso de tais iniciativas, ou seja, "os legisladores podem ser motivados a fiscalizar, mas não dispõem de meios para exercer um controle efetivo do Executivo.” (p. 715).

As CPIs produzem leituras diferentes sobre seu mecanismo e sua natureza quando olhamos a lógica governo/oposição. Para a oposição, o dispositivo das CPIs significa a possibilidade de investigar o Executivo e seus aliados, de produzir e dar seguimento a denúncias de irregularidades e corrupção e, mais do que isso, uma forma de emplacar uma agenda política ao grande eleitorado. Já no caso do governo, qualquer proposta de CPI com fins de investigação em área cara aos interesses do executivo e do eleitorado é identificada como ameaça política para o seu capital político e dos que o apoiam.

Nesse contexto, são diversas as estratégias utilizadas pelos governistas para constranger a ocorrência de uma CPI que desagrade o interesse do governo, com destaque para argumentar, via Plenário e imprensa, que a CPI é obstáculo para o funcionamento da Casa Legislativa e iniciar processos de barganha para cooptar deputados independentes ou de oposição, afim de não permitir que seja atingido o quorum mínimo necessário para sua criação. Outro artifício é o de não indicar nomes para a CPI, para inviabilizar a sua instalação. Após todas essas possibilidades de ação visando a constranger a criação e instalação de CPIs, os governistas, contando com maioria na Casa, podem adotar ações amparadas nos regimentos internos das Casas Legislativas para limitar o poder do inquérito ou, ao menos, mantê-lo sob controle da bancada do governo, através dos cargos estratégicos de presidente e relator.

As figuras do presidente e do relator das CPIs são centrais e dizem respeito, em última instância, à qualidade do inquérito desenvolvido. $\mathrm{O}$ governo, através de maioria na Casa, pode escolher presidente e relator da bancada, excluindo a participação da minoria nesses postos, que concentram as principais prerrogativas das CPIs. Além disso, a maioria governista pode rejeitar os requerimentos de convocação de depoimentos relevantes para o 
inquérito e substituir membros governistas nomeados pelas bancadas, mas que desenvolvam postura independente na comissão, por membros que atendam à postura desejada pelo Executivo (principalmente, nos momentos que antecedem as votações de relatórios finais). Somado a isso, o presidente tem prerrogativa de definir a agenda e pode protelar a data de votação do relatório final, até que se encerrem os prazos.

\subsection{CPIs nos Estados}

Analisamos os regimentos internos das 20 Casas Legislativas, contidas nesta amostra, com o objetivo de explicitar os dispositivos regimentais acerca da limitação de CPIs em funcionamento e os requisitos para a sua instalação. Podemos acompanhar, no quadro a seguir, a diversidade de desenho institucional sobre a normatização das CPIs nas diferentes Casas Legislativas contidas na amostra:

Quadro 5. Desenho Institucional das CPIs nas Assembleias Legislativas

\begin{tabular}{|c|c|c|c|}
\hline \multicolumn{4}{|c|}{ DESENHO INSTITUCIONAL } \\
\hline $\begin{array}{c}\text { Limitação Regimental do } \\
\text { Numero de CPIs em } \\
\text { andamento. }\end{array}$ & $\begin{array}{c}\text { Requisito de } \\
\text { Assinatura de 1/4 } \\
\text { dos Deputados via } \\
\text { Reque rime nto }\end{array}$ & $\begin{array}{c}\text { Requisito de } \\
\text { Assinatura de } 1 / 3 \text { dos } \\
\text { Deputados via } \\
\text { Requerimento }\end{array}$ & $\begin{array}{c}\text { Requisito de } \\
\text { Assinatura de 1/3 dos } \\
\text { Deputados via } \\
\text { Reque rimento + } \\
\text { Aprovação do } \\
\text { Plenário }\end{array}$ \\
\hline Limite de 7 CPIs Simultâneas & & Rio de Janeiro & \\
\hline Limite de 6 CPIs simultâneas & & Minas Gerais & \\
\hline Limite de 5 CPIs simultâneas & & $\begin{array}{l}\text { Bahia, Espírito Santo, } \\
\text { Maranhão, Pernambuco }\end{array}$ & Goiás, São Paulo \\
\hline Limite de 3 CPIs simultâneas & & $\begin{array}{l}\text { Mato Grosso do Sul, } \\
\text { Sergipe }\end{array}$ & Acre, Amapá \\
\hline Limite de 2 CPIs simultâneas & Ceará & & $\begin{array}{l}\text { Distrito } \\
\text { Federal,Tocantins }\end{array}$ \\
\hline $\begin{array}{l}\text { Sem Limitação Regimental no } \\
\text { Numero de CPIs simultâneas }\end{array}$ & & $\begin{array}{l}\text { Amazonas, Rio Grande do } \\
\text { Norte, Rio Grande do Sul }\end{array}$ & \\
\hline
\end{tabular}

Fonte: Elaboração do Autor 
Da observação do quadro, podemos inferir sobre processos e regras internas (regimentais) mais ou menos permissivos para a utilização do mecanismo das CPIs. Três estados (Amazonas, Rio Grande do Norte e Rio Grande do Sul) destacam-se pelos menores constrangimentos à abertura e instalação de CPIs quando olhamos em perspectiva comparada. Neles, o regimento interno não limita o número de CPIs, que podem funcionar simultaneamente, além de prever processos de instalação menos restritivos, de modo que uma CPI pode ser requerida e instalada via assinatura de 1/3 dos deputados estaduais. Já o Distrito Federal e Tocantins apresentam os processos mais restritivos à instalação de CPIs; nos dois estados, somente $2 \mathrm{CPIs}$ podem funcionar simultaneamente, e o requerimento para a sua instalação deve conter $1 / 3$ das assinaturas dos deputados estaduais, mais a aprovação do Plenário. Assim, o quadro acima permitirá, no futuro, testarmos nossa hipótese quanto ao desenho institucional.

Na Legislatura 2007-2010, ocorreram 66 CPIs nos 20 estados brasileiros contidos nesta amostra, cuja distribuição não foi uniforme, sendo que estas se concentraram mais em alguns estados do que em outros; em 4 estados da amostra, nenhuma CPI foi instalada durante esses quatro anos: Minas Gerais, Sergipe, Ceará e Rio Grande do Norte. Segue tabela que mostra a distribuição das CPIs nos diferentes estados: 
Tabela 3. Distribuição do Total de CPIs por Estados

\begin{tabular}{|c|c|}
\hline ESTADO & $\begin{array}{c}\text { Porcentagem de CPIs } \\
\text { por Estado }\end{array}$ \\
\hline AC & $1,52 \%(1)$ \\
\hline AM & $1,52 \%(1)$ \\
\hline AP & $1,52 \%(1)$ \\
\hline BA & $3,03 \%(2)$ \\
\hline DF & $6,06 \%(4)$ \\
\hline ES & $7,58 \%(5)$ \\
\hline GO & $7,58 \%(5)$ \\
\hline MA & $3,03 \%(2)$ \\
\hline MS & $1,52 \%(1)$ \\
\hline MT & $4,55 \%(3)$ \\
\hline PE & $1,52 \%(1)$ \\
\hline RJ & $18,18 \%(12)$ \\
\hline RO & $3,03 \%(2)$ \\
\hline RS & $6,06 \%(4)$ \\
\hline SP & $30,30 \%(20)$ \\
\hline TO & $3,03 \%(2)$ \\
\hline TOTAIS & $\mathbf{1 0 0} \%(\mathbf{6 6})$ \\
\hline
\end{tabular}

Fonte: Elaboração do Autor

Os resultados variam de uma única CPI instalada (Acre, Amazonas, Amapá, Mato Grosso do Sul e Pernambuco) na legislatura selecionada até vinte, em um único estado, tendo sido São Paulo e Rio de Janeiro os estados que mais instalaram CPIs na Legislatura 2007-2010. Quando olhamos os dados da tabela 3 em conjunto com os dados apresentados na tabela 1, podemos comprovar a fragilidade de nossa hipótese 1 que preceitua que o tamanho da coalizão determinaria a variação de instalação de CPIs nos estados. . No estado do Maranhão, em que o governo obteve modesta base governista (47,6\% de deputados), ocorreram apenas 2 CPIs (3,03\% do total ocorridas no país); já nos estados com coalizões majoritárias, como Rio de Janeiro (75,7\% de deputados estaduais membros da base governista) e São Paulo, com 76,6\% de deputados na base governista, foi onde ocorreram 32 CPIs no período, quase $50 \%$ do total de CPIs ocorridas no país na legislatura 2007-2010. Embora com uma amostra reduzida e circunscrita temporalmente, pode-se inferir que esses dados enfraquecem a hipótese 1 da 
pesquisa e indicam que a instalação e a quantidade de CPIs nos estados independem do tamanho quantitativo da coalizão governista na Assembleia.

$\mathrm{O}$ resultado relevante aparece quando olhamos a tabela concomitantemente às prerrogativas constitucionais legislativas nas mãos do governador nos diferentes estados, reforçando a hipótese 3 (prerrogativas constitucionais) de nosso trabalho. Segue quadro elaborado por Clemente (2006). 


\section{Quadro 6. Poderes Legislativos dos Governadores}

\begin{tabular}{|c|c|}
\hline ACRE & $\begin{array}{l}\text { Medida Provisória + Lei Delegada + Possibilidade de Delegação para Matéria } \\
\text { Orçamentária + Iniciativa Privativa de Serviços Públicos + Iniciativa privativa } \\
\text { do Governador para legislação Referente a Matéria Tributária, financeira e } \\
\text { orçamentária+ Iniciativa privativa do Governador para legislação Referente a } \\
\text { Empresas de Economia mista ou públicas }\end{array}$ \\
\hline TOCANTINS & $\begin{array}{l}\text { Medida Provisória + Lei Delegada + Iniciativa Privativa de Serviços } \\
\text { Públicos+Iniciativa privativa do Governador para legislação Referente a } \\
\text { Matéria Tributária, financeira e orçamentária + Iniciativa privativa do } \\
\text { Governador para legislação Referente a Empresas de Economia mista ou } \\
\text { públicas }\end{array}$ \\
\hline MARANHÃO & $\begin{array}{l}\text { Medida Provisória + Iniciativa Privativa de Serviços Públicos + Iniciativa } \\
\text { privativa do Governador para legislação Referente a Matéria Tributária, } \\
\text { financeira e orçamentária+ Iniciativa privativa do Governador para legislação } \\
\text { Referente a Empresas de Economia mista ou públicas }\end{array}$ \\
\hline $\begin{array}{c}\text { BAHIA, CEARÁ, } \\
\text { GOIÁS }\end{array}$ & $\begin{array}{l}\text { Lei Delegada + Possibilidade de Delegação para Matéria Orçamentária + } \\
\text { Iniciativa Privativa de Serviços Públicos+Iniciativa privativa do Governador } \\
\text { para legislação Referente a Matéria Tributária, financeira e orçamentária+ } \\
\text { Iniciativa privativa do Governador para legislação Referente a Empresas de } \\
\text { Economia mista ou públicas }\end{array}$ \\
\hline $\begin{array}{l}\text { AMAZONAS, } \\
\text { AMAPÁ, MINAS } \\
\text { GERAIS }\end{array}$ & $\begin{array}{l}\text { Lei Delegada+ Iniciativa Privativa de Serviços Públicos + Iniciativa privativa do } \\
\text { Governador para legislação Referente a Matéria Tributária, financeira e } \\
\text { orçamentária+ Iniciativa privativa do Governador para legislação Referente a } \\
\text { Empresas de Economia mista ou públicas }\end{array}$ \\
\hline MATO GROSSO & $\begin{array}{l}\text { Lei Delegada+ Iniciativa Privativa de Serviços Públicos + Iniciativa privativa do } \\
\text { Governador para legislação Referente a Empresas de Economia mista ou } \\
\text { públicas }\end{array}$ \\
\hline $\begin{array}{l}\text { PERNAMIBUCO, } \\
\text { SERGIPE }\end{array}$ & $\begin{array}{l}\text { Lei Delegada + Iniciativa privativa do Governador para legislação Referente a } \\
\text { Matéria Tributária, financeira e orçamentária+ Iniciativa privativa do } \\
\text { Governador para legislação Referente a Empresas de Economia mista ou } \\
\text { públicas }\end{array}$ \\
\hline $\begin{array}{l}\text { MATO GROSSO DO } \\
\text { SUL, RIO DE } \\
\text { JANEIRO, RIO } \\
\text { GRANDEDO NORTE }\end{array}$ & $\begin{array}{l}\text { Lei Delegada + Iniciativa privativa do Governador para legislação Referente a } \\
\text { Empresas de Economia mista ou públicas }\end{array}$ \\
\hline RONDÔNIA & Lei Delegada \\
\hline DISTRITO FEDERAL & $\begin{array}{l}\text { Iniciativa privativa do Governador para legislação Referente a Matéria } \\
\text { Tributária, financeira e orçamentária }\end{array}$ \\
\hline $\begin{array}{l}\text { ESPÍRITO SANTO, } \\
\text { RIO GRANDEDO } \\
\text { SUL }\end{array}$ & $\begin{array}{l}\text { Iniciativa privativa do Governador para legislação Referente a Empresas de } \\
\text { Economia mista ou públicas }\end{array}$ \\
\hline
\end{tabular}

Fonte: (CLEMENTE, 2007) Adpatada. 
Como podemos observar, as prerrogativas legislativas dos governadores diferem entre os estados da amostra. Em todos eles, os governadores compartilham da necessidade de solicitar urgência e convocação extraordinária do Legislativo em projetos que julgam urgentes; além disso, todo governador tem a prerrogativa de legislação orçamentária (Plano Plurianual, Lei Orçamentária e Lei de Diretrizes Orçamentárias). No entanto, os estados divergem, por exemplo, quanto aos instrumentos legislativos poderosos, ${ }^{4}$ como a prerrogativa de editar medidas provisórias (que permite ao governador legislar à revelia da apreciação do Legislativo estadual) e de instituir leis delegadas. ${ }^{5}$

As Constituições estaduais de Acre, Maranhão e Tocantins dotam o governador desses dois mecanismos legislativos, os quais estão ausentes nos estados de São Paulo, Rio Grande do Sul, Espírito Santo e Distrito Federal. Para fins de didatismo, Clemente (2007) sintetizou as variáveis através de um índice no qual classificou os poderes legislativos dos governadores como altos ou baixos. Os estados em que o governador possui ou a prerrogativa de medida provisória, ou lei delegada, ou as duas, foram classificados como estados em que o governador possui altos poderes legislativos; já os estados nos quais esses mecanismos não constam da Constituição Estadual foram classificados como de governador com baixos poderes legislativos.

\section{Quadro 7. Classificação do Poder Legislativo dos Governadores}

\begin{tabular}{|l|l|}
\hline ALTO & $\begin{array}{l}\text { Acre, Amazonas, Amapa, Bahia, Ceará, Goiás, Maranhão, Mato Grosso, } \\
\text { Mato Grosso do Sul, Minas Gerais, Pernambuco, Rio de Janeiro, Rio Grande } \\
\text { do Norte, Rondônia, Sergipe e Tocantins }\end{array}$ \\
\hline BAIXo & Distrito Federal, Espírito Santo, Rio Grande do Sul, São Paulo
\end{tabular}

Fonte: (CLEMENTE, 2007) Adpatada.

Os quatro estados em que os governadores possuem baixos poderes legislativos concentram 50\% do total de CPIs instaladas nos 20 estados, na legislatura 2007-2010, ou seja,

\footnotetext{
${ }^{4}$ Tanto o mecanismo das medidas provisórias quanto o das leis delegadas são prerrogativas do Presidente da República.

5 Segundo Clemente (2006, p. 41), "o instrumento da Lei Delegada pode ser uma carta branca sobre determinada matéria, com aprovação legislativa prévia. No caso das duas delegações conferidas pela Assembleia mineira ao governador Aécio Neves, o Legislativo mineiro delegou todo o poder para efetuar as Reformas Administrativas, sem qualquer controle prévio ou posterior".
} 
das 66 CPIs que ocorreram nos Legislativos estaduais do país, 33 ocorreram em São Paulo, Espírito Santo, Rio Grande do Sul e Distrito Federal. Embora necessite de maiores aprofundamentos analíticos, nossa descrição pode reforçar uma das hipóteses desta dissertação: quanto menores as prerrogativas legislativas nas mãos dos governadores, maior a pró-atividade de fiscalização e controle dos Legislativos estaduais via CPIs. No entanto, o tal achado é meramente descritivo e, certamente, não podemos afirmar se essas variáveis estão devidamente associadas ou se encontramos mera associação espúria, já que, em recente trabalho denominado O Poder da Caneta. A Medida Provisória no Poder Legislativo Estadual, Ricci e Tomio (2012) apresentam resultados consistentes em relação ao real impacto dessas prerrogativas nas mãos de alguns governadores estaduais. Segundo os achados dos autores, a prerrogativa de editar medidas provisórias é pouco utilizada e não representa expediente comum nos seis estados da federação em que essa prerrogativa existe. Devido ao próprio desenho das instituições estaduais, o Executivo (diferentemente do que ocorre na esfera federal) não necessitaria de lançar mão de tal recurso. Os recursos institucionais nas mãos dos governadores garantem o domínio da limitada agenda política nos estados, independentemente da existência do direito de editar MPs, conferidas por seis Constituições estaduais.

\subsection{Objetivo das CPIs}

A Constituição Federal estabelece que uma CPI pode ser instalada mediante fato determinado descrito em seu requerimento. Portanto, basta que haja a descrição de um fato passível de investigação para que o requerimento esteja de acordo com as prescrições constitucionais. No entanto, é sabido que os atores podem adotar a estratégia de instalar CPIs com temas diversos (que não fiscalizam o poder legislativo), com o objetivo de atingir o número regimental de CPIs em funcionamento simultaneamente, impossibilitando a instalação daquelas com o objetivo de fiscalizar o governo ou nocivas aos interesses desse poder.

Nesse contexto, parlamentares da coalizão governista propõem CPIs com temas diversos que não envolvem diretamente o Poder Executivo, suas agências e secretarias, como 
descreve Figueiredo (2002, p. 707): “Questões cuja investigação os partidos governistas não tinham razão para se opor, já que não envolviam diretamente agências do governo - as causas da fome; a chacina de crianças de rua; violência em áreas rurais; criminalidade no centrooeste do país etc."

Cientes disso, criamos a variável InvestGov, com o objetivo de separar CPIs com temas de relevância social, porém, sem objetivo de fiscalizar o Executivo estadual, de CPIs com o objetivo específico e descrito em requerimento de fiscalizar o Poder Executivo e/ou suas secretarias e agências ${ }^{6}$. Segue quadro que resume os resultados:

Tabela 4. Objetivo das CPIs em 20 Assembleias Estaduais na Legislatura 2007-2010

\begin{tabular}{|c|c|}
\hline $\begin{array}{c}\text { CPIS COM OBJETIVOS } \\
\text { DIVERSOS }\end{array}$ & $\begin{array}{c}\text { CPIS COM OB JETIVO DE } \\
\text { FISCALIZAR O PODER } \\
\text { EXECUTIVO }\end{array}$ \\
\hline $80,30 \%(53)$ & $19,69 \%(13)$ \\
\hline Total: $\mathbf{1 0 0 \%}(\mathbf{6 6})$ & \\
\hline
\end{tabular}

Fonte: Elaboração do Autor

Apenas 19,69\% das CPIs instaladas em 20 Assembleias, na legislatura 2007-2010 tiveram como objetivo fiscalizar o Executivo estadual. Por outro lado, 80,30\% tiveram como objetivo fiscalizar temas diversos, sem qualquer ligação com o Executivo estadual. São exemplos das primeiras: CPI da Gautama (Distrito Federal), CPI da Corrupção (Rio Grande do Sul), CPI do Detran (Rio Grande do Sul), CPI da CDHU (São Paulo), CPI da Saúde (Goiás); e exemplos das segundas: CPI da Telefonia (São Paulo), CPI das Gorjetas (São Paulo), CPI da Violência Sexual (Acre) e CPI da Pedofilia (Espírito Santo, São Paulo, Goiás, Amazonas e Amapá). A tabela a seguir demonstra a distribuição desses 19,69\% de CPIs com objetivo de fiscalizar o Executivo nos estados.

\footnotetext{
${ }^{6}$ Em março de 2011, em decisão inédita, o Tribunal de Justiça de São Paulo determinou a suspensão da formação de cinco CPIs na Alesp criadas pela base governista. A liminar do desembargador foi motivada pelo requerimento de um Deputado da oposição. Segundo o deputado Antônio Mentor, do PT, essas CPIs não indicaram fato determinado de acordo com o rigor constitucional exigido. Segundo o deputado estadual, os temas propostos eram de natureza generalista e altamente vagos. As CPIs propostas pela base do Governador tinham como objetivo fiscalizar: o serviço de TV a cabo, dentaduras e implantes dentários, alcoolismo no estado, valor pago aos médicos nos planos de saúde e o ensino superior privado.
} 
Tabela 5. Porcentagem de CPIs que Fiscalizam o Executivo Estadual

\begin{tabular}{|c|c|c|}
\hline ESTADO & $\begin{array}{c}\text { Total de CPIs por } \\
\text { Estado }\end{array}$ & $\begin{array}{l}\text { CPIs que fiscalizam o } \\
\text { Governo Estadual } \\
\text { (Executivo) }\end{array}$ \\
\hline $\mathrm{AC}$ & 1 & $0,00 \%$ \\
\hline AM & 1 & $0,00 \%$ \\
\hline AP & 1 & $0,00 \%$ \\
\hline $\mathrm{BA}$ & 2 & $0,00 \%$ \\
\hline DF & 4 & $75,00 \%(3)$ \\
\hline ES & 5 & $0,00 \%$ \\
\hline GO & 5 & $60,00 \%$ (3) \\
\hline MA & 2 & $0,00 \%$ \\
\hline MS & 1 & $0,00 \%$ \\
\hline MT & 3 & $33,33 \%(1)$ \\
\hline $\mathrm{PE}$ & 1 & $0,00 \%$ \\
\hline RJ & 12 & $0,00 \%$ \\
\hline $\mathrm{RO}$ & 2 & $0,00 \%$ \\
\hline $\mathrm{RS}$ & 4 & $75,00 \%$ (3) \\
\hline SP & 20 & $10,00 \%$ (2) \\
\hline TO & 2 & $50,00 \%$ (1) \\
\hline TOTAIS & 66 & $19,69 \%(13)$ \\
\hline
\end{tabular}

Fonte: Elaboração do Autor

Estados como Acre, Maranhão, Rio de Janeiro, Amazonas, Amapá, Mato Grosso do Sul e Pernambuco não realizaram nenhuma CPI com o objetivo de fiscalizar o Executivo estadual. Em contrapartida, em estados como Rio Grande do Sul e o Distrito Federal,* 3/4 do total das CPIs instaladas tinham como objetivo fiscalizar diretamente o Poder Executivo e/ou suas secretarias e agências.

Como já verificado, São Paulo e Rio de Janeiro foram os estados protagonistas no número de CPIs instaladas, no entanto, no que corresponde aos objetivos delas, em São Paulo, apenas 2 das 20 CPIs tinham como objetivo fiscalizar o Executivo estadual, sendo que uma delas não concluiu os trabalhos. No Rio de Janeiro, das doze CPIs instaladas na legislatura 2007-2010, nenhuma teve por objetivo fiscalizar o governo Sergio Cabral e/ou suas secretarias. 


\subsection{Cargos-Chave (Presidência e Relatoria) sob a Lógica Governo x Oposição}

As CPIs, após serem criadas, devem observar, no ato de sua constituição, tanto quanto possível, a proporcionalidade dos partidos políticos na Casa Legislativa em seus membros efetivos e postos-chave (presidência e relatoria). Portanto, o direito da minoria de criar uma CPI é matizado pela proporcionalidade partidária, sempre equacionada sob fórmulas que garantam a representação e a ocupação dos postos-chave pela coalizão majoritária. Como afirma Pereira,

O direito da Minoria de requerer a instalação de Comissão Parlamentar de Inquérito é constitucional, regimental e consagrado por decisões do Supremo Tribunal Federal. No entanto, a composição proporcional das vagas nas Comissões impõe uma maioria governista que decide sobre os requerimentos aprovados, sobre as autoridades convocadas e sobre o relatório final encaminhado ao Judiciário. (2010:29)

Desse modo, a Comissão Parlamentar de Inquérito refletirá, em sua composição, a correlação de forças políticas representadas no Parlamento como um todo, e não apenas da minoria parlamentar que a cria. Os cargos de presidente e relator concentram prerrogativas fundamentais no processo decisório das CPIs, incidindo, diretamente, sobre os rumos e o desempenho do inquérito parlamentar. ${ }^{7}$ Ao classificar presidentes e relatores das 66 CPIs instaladas na lógica governo/oposição, buscamos responder a uma pergunta fundamental: quem decide os rumos das comissões?

Pereira (2010) realizou estudo de caso sobre a CPI do Tráfego Aéreo, que ocorreu na Câmara dos Deputados com o objetivo de elucidar as questões concernentes à representação proporcional e às minorias parlamentares. Segundo Pereira, o direito constitucional da minoria em propor CPIs é usurpado pelo mecanismo que prevê representação proporcional aos partidos da Casa dentre os componentes das comissões. Dessa forma, a maioria consegue

\footnotetext{
${ }^{7}$ Ao concluir estudo de caso sobre a CPI da Crise do Tráfego Aéreo na Câmara dos Deputados, Pereira afirma que: "Os resultados demonstram que o voto da maioria determina o resultado da investigação parlamentar, frustrando as pretensões da minoria ao requerer a criação de Comissões Parlamentares de Inquérito.” (PEREIRA, 2010, 29)
} 
não só eleger presidentes e relatores das CPIs, como também ganhar todas as votações sobre decisões do inquérito parlamentar. À minoria, resta o uso da palavra, já que a convocação de testemunhas, os requerimentos de informação ao Executivo são rejeitados pela maioria governista. O presidente e o relator da comissão constrangem a atuação das minorias parlamentares ao interpretar de maneira diversa e barrar os pedidos de requerimentos referentes a informações sobre procedimentos administrativos feitos pela minoria. Assim, o relatório final redigido pelo relator acaba por matizar e desviar os propósitos iniciais da CPIs criada com base em requerimento da minoria.

Segue abaixo quadro que resume os achados desta dissertação em relação aos cargoschave sob a lógica Governo/Oposição nas CPIs dos Legislativos Estaduais.

Tabela 6. Cargos-Chave sob a Lógica Governo x Oposição, em 20 Assembleias na Legislatura 2007-2010

\begin{tabular}{|c|c|c|}
\hline CARGOS-CHAVE CPI & $\begin{array}{c}\text { MEMBRO DA BASE } \\
\text { GOVERNISTA }\end{array}$ & $\begin{array}{c}\text { MEMBRO DA OPOSIÇÃ̃ } \\
\text { OU INDEPENDENTE }\end{array}$ \\
\hline Autor de CPI & $74,24 \%(49)$ & $25,76 \%(17)$ \\
\hline Presidente de CPI & $83,33 \%(55)$ & $16,67 \%(11)$ \\
\hline Relator de CPI & $60,60 \%(40)$ & $39,40 \%(16)$ \\
\hline Total de CPIs: 100\% (66) & & \\
\hline
\end{tabular}

Fonte: Elaboração do Autor

O protagonismo dos membros da banca governista ocorre nos três atores/cargoschave nas Comissões Parlamentares de Inquérito que responde a pergunta colocada por nós sobre "quem decide?", ou seja, a larga maioria dos postos estratégicos no interior dessas CPIs ficou na mão de parlamentares e partidos da base do governador. Destaque para o principal cargo que define o centro do processo decisório nas CPIs, membros das bancadas governistas ocupam 83,33\% das Presidências das Comissões. Das 66 CPI que ocorreram na Legislatura 2007-2010 nesses estados, apenas 11 tiveram como presidentes membros que não faziam parte da coalizão governista. 
Tabela 7. Cargos-Chave das CPIs sob a Lógica Governo x Oposição, por Estado na Legislatura 2007-2010

\begin{tabular}{|c|c|c|c|c|}
\hline ESTADO & $\begin{array}{c}\text { Número de } \\
\text { CPIs } \\
\text { (por Estado) }\end{array}$ & $\begin{array}{c}\text { Autor da CPI } \\
\text { membro da Coalizão } \\
\text { Governista }\end{array}$ & $\begin{array}{c}\text { Presidente da CPI } \\
\text { membro da Coalizão } \\
\text { Governista }\end{array}$ & $\begin{array}{c}\text { Relator da CPI } \\
\text { membro da Coalizão } \\
\text { Governista }\end{array}$ \\
\hline AC & 1 & $100 \%(1)$ & $100 \%(1)$ & $100 \%(1)$ \\
\hline AM & 1 & $100 \%(1)$ & $100 \%(1)$ & $100 \%(1)$ \\
\hline AP & 1 & $100 \%(1)$ & $100 \%(1)$ & $100 \%(1)$ \\
\hline BA & 2 & $50 \%(1)$ & $100 \%(2)$ & $100 \%(2)$ \\
\hline DF & 4 & $25 \%(1)$ & $75 \%(3)$ & $75 \%(3)$ \\
\hline ES & 5 & $100 \%(5)$ & $100 \%(5)$ & $100 \%(5)$ \\
\hline GO & 5 & $80 \%(4)$ & $100 \%(5)$ & $60 \%(3)$ \\
\hline MA & 2 & $0,0 \%$ & $0,0 \%$ & $100 \%(1)$ \\
\hline MS & 1 & $100 \%(1)$ & $100 \%(1)$ & $33,33 \%(1)$ \\
\hline MT & 3 & $100 \%(3)$ & $100 \%(3)$ & $100 \%(1)$ \\
\hline PE & 1 & $100 \%(1)$ & $100 \%(1)$ & $83,33 \%(10)$ \\
\hline RJ & 12 & $66,66 \%(8)$ & $66,66 \%(8)$ & $100 \%(2)$ \\
\hline RO & 2 & $100 \%(2)$ & $100 \%(2)$ & $100 \%(4)$ \\
\hline RS & 4 & $25 \%(1)$ & $25 \%(1)$ & $85 \%(3)$ \\
\hline SP & 20 & $90 \%(18)$ & $95 \%(19)$ & $100 \%(2)$ \\
\hline TO & 2 & $50 \%(1)$ & $100 \%(2)$ & $\mathbf{6 0 , 6 0 \% ( 4 0 )}$ \\
\hline TOTAIS & $\mathbf{6 6}$ & $\mathbf{7 4 , 2 4 \% ( 4 9 )}$ & $\mathbf{8 3 , 3 3 \% ( 5 5 )}$ & \\
\hline Fo & & & $(1)$ \\
\hline
\end{tabular}

Fonte: Elaboração do Autor

No que tange à autoria das CPIs, o protagonismo dos parlamentes fora da coalizão governista só se deu no Distrito Federal e no Rio Grande do Sul. Em São Paulo, 90\% das CPIs instaladas tiveram, como origem, parlamentares governistas. Em 11 dos 16 estados, $100 \%$ dos parlamentares que ocuparam o cargo de presidente eram da coalizão governista. Apenas no Rio Grande do Sul, a maioria das CPIs não teve, como presidente, membros da coalizão do governo. Na Assembleia Legislativa do Rio Grande do Sul, do total das CPIs instaladas, apenas $25 \%$ delas tiveram, como presidentes, membros coalizão da governadora Yeda Crusius. Em contrapartida, nesse mesmo estado, 100\% dos parlamentes designados para serem relatores eram da coalizão majoritária. O estado do Mato Grosso foi único onde a coalizão majoritária não nomeou a maioria dos relatores. 
A fim de observar se há mudança nas tendências quando filtramos as CPIs, por seu objetivo, analisamos em separado os $25,75 \%$ do total de CPIs que tiveram por objetivo fiscalizar o poder Executivo Estadual em relação à ocupação dos postos-chave na lógica governo/oposição. Segue abaixo a síntese do resultado encontrado.

\section{Tabela 8. Distribuição dos Cargos-Chave nas CPIs com Objetivo de Fiscalizar o Executivo}

\begin{tabular}{|c|c|c|}
\hline \multicolumn{2}{|c|}{ CPIS COM OBJETIVO DE FISCALIZAR O PODER EXECUTIVO ESTADUAL } \\
\hline Cargos-Chave CPI & Membro da Base Governista & $\begin{array}{c}\text { Membro da Oposição ou } \\
\text { Independente }\end{array}$ \\
\hline Autor de CPI & $38,46 \%(5)$ & $61,54 \%(8)$ \\
\hline Presidente de CPI & $76,92 \%(10)$ & $23,08 \%(3)$ \\
\hline Relator de CPI & $69,23 \%(9)$ & $30,77 \%(4)$ \\
\hline Total de CPIs: 100\% (13) & & \\
\hline
\end{tabular}

Fonte: Elaboração do Autor

No caso das CPIs com objetivo descrito de fiscalizar o Executivo Estadual, temos o acréscimo de autores fora da coalizão governista. Enquanto, no geral, os membros da oposição ou independentes conseguiram emplacar 25,76\% das CPIs, quando olhamos somente aquelas com objetivo de fiscalizar o governador e ou suas secretarias, os membros de fora da coalizão conseguiram emplacar $61,54 \%$ dessas. A elevação da participação dos membros de fora da coalizão não teve o mesmo crescimento em relação aos postos estratégicos no processo decisório das CPIs. A taxa de ocupação da presidência por membros da coalizão governista foi de 82,36\% no total das 66 CPIs, sendo que, das 13 CPIs com objetivo de fiscalizar o governo estadual, apenas 3 tiveram, como seus presidentes, membros de fora da coalizão governista do Executivo Estadual. No que concerne aos relatórios finais documentos fundamentais para auxiliar responsabilização ou aprofundamento de investigações por outras instituições - apenas 4 (30,77\%) das 13 CPIs tiveram como relatores deputados estaduais que não faziam parte da coalizão governista. 
Tabela 9. Distribuição dos Cargos-Chave nas CPIs com Objetivo de Fiscalizar o Executivo, Desagregado por Estado

\begin{tabular}{|c|c|c|c|c|}
\hline ESTADO & $\begin{array}{l}\text { Número de CPIs } \\
\text { com objetivo de } \\
\text { Fis calizar o } \\
\text { Governo Estadual } \\
\text { (por Estado) }\end{array}$ & $\begin{array}{l}\text { CPI com Autor } \\
\text { membro de } \\
\text { Partidos da Base } \\
\text { Governista }\end{array}$ & $\begin{array}{c}\text { CPI com } \\
\text { Presidente membro } \\
\text { de Partidos da } \\
\text { Base Governista }\end{array}$ & $\begin{array}{l}\text { CPI com Relator } \\
\text { membro de } \\
\text { Partidos da Base } \\
\text { Governista }\end{array}$ \\
\hline $\mathrm{AC}$ & 0 & $0,0 \%$ & $0,0 \%$ & $0,0 \%$ \\
\hline $\mathrm{AM}$ & 0 & $0,0 \%$ & $0,0 \%$ & $0,0 \%$ \\
\hline AP & 0 & $0,0 \%$ & $0,0 \%$ & $0,0 \%$ \\
\hline BA & 0 & $0,0 \%$ & $0,0 \%$ & $0,0 \%$ \\
\hline DF & 3 & $33,33 \%$ & $100 \%$ & $66,66 \%$ (2) \\
\hline ES & 0 & $0,0 \%$ & $0,0 \%$ & $0,0 \%$ \\
\hline GO & 3 & $66,66(2)$ & $100 \%$ & $33,33 \%(1)$ \\
\hline MA & 0 & $0,0 \%$ & $0,0 \%$ & $0,0 \%$ \\
\hline MS & 0 & $0,0 \%$ & $0,0 \%$ & $0,0 \%$ \\
\hline MT & 1 & $100 \%$ & $100 \%$ &, $0 \%$ \\
\hline PE & 0 & $0,0 \%$ & $0,0 \%$ & $0,0 \%$ \\
\hline RJ & 0 & $0,0 \%$ & $0,0 \%$ & $0,0 \%$ \\
\hline $\mathrm{RO}$ & 0 & $0,0 \%$ & $0,0 \%$ & $0,0 \%$ \\
\hline $\mathrm{RS}$ & 3 & $33,33 \%(1)$ & $33,33 \%(1)$ & $100 \%$ (3) \\
\hline SP & 2 & $0,0 \%$ & $50 \%(1)$ & $100 \%(2)$ \\
\hline TO & 1 & $0,0 \%$ & $100 \%(1)$ & $100 \%(1)$ \\
\hline TOTAIS & 13 & $58,83 \%(10)$ & $82,36 \%(14)$ & $76,48 \%(13)$ \\
\hline
\end{tabular}

Fonte: Elaboração do Autor

Os parlamentares que não faziam parte da coalizão governista conseguiram instalar CPIs de sua autoria, com objetivo de fiscalizar o Executivo, no Rio Grande do Sul, Goiás, Tocantins, Mato Grosso, São Paulo e no Distrito Federal. No entanto, no caso de Goiás, Tocantins, Mato Grosso e Distrito Federal, 100\% dos presidentes dessas CPIs eram membros da coalizão governista e no Rio Grande do Sul, em São Paulo e no Tocantins, $100 \%$ dos relatores eram da base de apoio aos governadores em exercício. 


\subsection{Desempenho das CPIs: Análise dos Relatórios Finais}

Levar em contar as prerrogativas institucionais é condição necessária na avaliação do desempenho de uma dada instituição de controle. Logo, não faria sentido, dentro do arcabouço institucional brasileiro, cobrar de uma única instituição de controle o cumprimento das três dimensões da accountability: monitoramento, investigação e responsabilização ou seja, só faz sentido cobrar das CPIs aquilo que elas, constitucionalmente, podem nos dar. Há um certo desconhecimento, por parte da opinião pública, do fato de que as CPIs se restringem à investigação e ao oferecimento de propostas e encaminhamentos, em seus relatórios finais, para outras instituições. Não compete a elas a responsabilização civil ou criminal dos envolvidos.

Do ponto de vista de suas conclusões, todas as CPIs devem apresentar um relatório à Mesa da Casa onde foram criadas. Nele, pode haver resoluções, projetos de lei, indiciamentos, encaminhamentos e recomendações aos outros poderes. Caberia à Câmara e/ou ao Senado dar continuidade às indicações legislativas; ao Ministério Público, promover a responsabilização criminal ou civil dos infratores; às polícias Civil e Federal, a continuidade à investigação criminal posterior; aos Tribunais de Contas, as possíveis sanções administrativas aos infratores. Como vimos, as CPIs, por sua natureza apenas investigatória, não têm atribuição constitucional de julgar ou impor penas. No marco jurídico nacional, devem produzir relatórios finais com recomendações e encaminhamentos às outras instituições para a responsabilização civil ou criminal dos envolvidos.

As comissões parlamentares de inquérito não são as últimas responsáveis pelo resultado final das investigações que conduzem, mas sim por outros três momentos importantes e prévios referentes aos resultados: chamar a atenção do público para um problema; forçar o início de investigações que, de outro modo, não ocorreriam; conduzir investigações que tanto se beneficiam da expertise das Assembleias como contribuem para o adensamento dessa expertise. A accountability horizontal pressupõe integração entre as instituições de controle. As instituições responsáveis pela efetivação dessa accountability horizontal não devem, como afirma O’Donnel, ser isoladas uma das outras, mas fazer parte de uma rede de instituições que tem como sua ação final a tomada de decisões nos tribunais, "pois é ali que o sistema constitucional se fecha mediante as decisões últimas" 
(O’DONNELL, 1998, p. 43). Portanto, a CPI pode ter um papel fundamental ao servir de subsídio para disparar os "alarmes de incêndio" e acionar a web of accountability (MAINWARRING et all, 2003)

Uma boa maneira de medir o desempenho de uma CPI é olhar para o seu relatório final. Assim, analisamos e classificamos o conteúdo dos relatórios finais das Comissões Parlamentares de Inquérito instaladas e concluídas nas Assembleias Legislativas brasileiras na Legislatura 2007-2010. Fizeram parte da amostra somente os estados em que todos os relatórios finais de CPIs instaladas na Legislatura 2007-2010 foram disponibilizados por meio impresso ou virtual. São eles: Espírito Santo, Rio Grande do Sul, São Paulo, Rondônia, Pernambuco, Mato Grosso do Sul, Mato Grosso, Goiás e Rio de Janeiro mais o Distrito Federal A motivação e o papel desse esforço é preencher a ausência, na literatura existente, de uma análise dos relatórios finais das CPIs, ou seja, do conteúdo final e das conclusões das Comissões. O procedimento adotado consistiu na leitura dos seus relatórios, anotando cada vez que a CPI fazia alguma recomendação ou acionava algum instrumento contido em nossa tipologia. A construção dessa tipologia foi feita com base em dois objetivos: o primeiro foi verificar o tipo de recomendações feitas pelas CPIs; o segundo, verificar, mais especificamente, quais instituições vêm sendo acionadas.

$\mathrm{Na}$ primeira tabela, podemos acompanhar as recomendações para os três poderes. Esse acionamento pode ser feito através de recomendações e/ou encaminhamentos: são desde recomendações de mudanças de políticas públicas até sugestões de mudanças organizacionais das instituições. As recomendações ao Executivo e Legislativo são, em sua maioria, orientações de caráter administrativo e organizacional, de alterações em secretarias e comissões, e englobam desde recomendações mais genéricas e amplas até as mais objetivas. Em relação ao Judiciário, as recomendações não se referem à responsabilização civil ou criminal; geralmente são recomendações para acelerar determinados processos ou mudar a organização de varas criminais, entre outros. Como podemos observar, na tabela abaixo, 75,5\% das CPIs analisadas fazem recomendações para os Poderes Executivo e Legislativo Estadual; no caso do Judiciário, apenas 16,3\% delas fazem recomendações. 
Tabela 10. Classificação do Conteúdo dos Relatórios Finais das CPIs. (Recomendações)

\begin{tabular}{|c|c|c|c|}
\hline ESTADO & $\begin{array}{c}\text { \% de CPIs que } \\
\text { Recomendam ao } \\
\text { Legislativo }\end{array}$ & $\begin{array}{c}\text { \% de CPIs que } \\
\text { Recomendam ao } \\
\text { Judiciário }\end{array}$ & $\begin{array}{c}\text { \% de CPIs que } \\
\text { Recomendam ao } \\
\text { Executivo }\end{array}$ \\
\hline DF & $66,66 \%(2)$ & $0,0 \%$ & $33,33 \%(1)$ \\
\hline ES & $33,33 \%(1)$ & $0,0 \%$ & $100 \%(3)$ \\
\hline GO & $60 \%(3)$ & $40 \%(2)$ & $20 \%(1)$ \\
\hline MS & $100 \%(1)$ & $0,0 \%$ & $100 \%(1)$ \\
\hline MT & $100 \%(1)$ & $0,0 \%$ & $100 \%(1)$ \\
\hline PE & $100 \%(1)$ & $0,0 \%$ & $100 \%(1)$ \\
\hline RJ & $80 \%(8)$ & $30 \%(3)$ & $100 \%(2)$ \\
\hline RO & $50 \%(1)$ & $0,0 \%$ & $100 \%(4)$ \\
\hline RS & $75 \%(3)$ & $0,0 \%$ & $73,7 \%(14)$ \\
\hline SP & $84,2 \%(16)$ & $15,8 \%(3)$ & $\mathbf{7 5 , 5 \% ( 3 7 )}$ \\
\hline TOTAIS (49) & $\mathbf{7 5 , 5 \% ( 3 7 )}$ & $\mathbf{1 6 , 3 \%}(\mathbf{8})$ & \\
\hline
\end{tabular}

Fonte: Elaboração do Autor

Na tabela a seguir, é possível notar as vezes em que as CPIs pediram indiciamentos e propuseram alterações de legislação. As Comissões Parlamentares de Inquérito podem, em seus relatórios finais, emitir propostas propriamente legislativas, como projetos de lei, e/ou propostas para alterar a legislação. Durante a investigação, os membros da Mesa apuram fatos e, muitas vezes, deparam-se com insuficiências, ausências e excessos na legislação. Diante disso, encaminham, no relatório final, propostas de projetos de lei e alterações na legislação. 
Tabela 11. Classificação do Conteúdo dos Relatórios Finais das CPIs. (Indiciamento e Projetos de Lei)

\begin{tabular}{|c|c|c|}
\hline ESTADO & $\begin{array}{c}\text { Relatório que produz } \\
\text { Indiciamento }\end{array}$ & $\begin{array}{c}\text { Relatórios que Propõem } \\
\text { alteração ou Criação de } \\
\text { Projeto de Lei }\end{array}$ \\
\hline DF & $33,33 \%(1)$ & $33,33 \%(1)$ \\
\hline ES & 0 & $33,33 \%(1)$ \\
\hline GO & $20 \%(1)$ & $20 \%(1)$ \\
\hline MS & 0 & $0,0 \%$ \\
\hline MT & 0 & $100 \%(1)$ \\
\hline PE & 0 & $100 \%(1)$ \\
\hline RJ & $10 \%(1)$ & $0,0 \%$ \\
\hline RO & 0 & $0,0 \%$ \\
\hline RS & 0 & $25 \%(1)$ \\
\hline SP & $5,2 \%(1)$ & $42,1 \%(8)$ \\
\hline TOTAIS (49) & $\mathbf{8 , 1 \% ( 4 )}$ & $\mathbf{2 8 , 6 \% ( 6 )}$ \\
\hline
\end{tabular}

Fonte: Elaboração do Autor

O número de CPIs que propõem projetos de leis e alterações na Legislação é relativamente baixo, apenas 6 das 49 CPIs analisadas produzem esse tipo de resultado. A tabela também nos mostra que os pedidos de indiciamento direto de pessoas físicas ou jurídicas não foram tão frequentes nos relatórios das Assembleias Legislativas, apenas 8,1\% do total de CPIs analisadas, o que corresponde, em números absolutos, a apenas 4 das 49 CPIs instaladas e concluídas. Esse dado indica baixo nível de pedidos de responsabilização via CPIs.

Na tabela abaixo, observamos o numero de vezes em que os relatórios finais das CPIs acionaram cada uma das principais instituições possíveis. Nota-se que as recomendações que levam à responsabilização criminal e civil pela Polícia Federal ou pelo Ministério Público relativizam aquelas conclusões no que se refere às tentativas de responsabilização por parte das CPIs. Não é porque não peçam sempre o indiciamento direto e nominal de investigados que as comissões não estejam atentas à necessidade de responsabilização. Todas as vezes que se aciona a Polícia Federal, e na maioria das vezes em que isso ocorre em relação ao Ministério Público, os relatórios referem-se a questões de responsabilização civil e criminal. Esse ponto é interessante, já que tanto o MP é responsável por processar os indiciados da CPI, 
como, algumas vezes, a própria CPI pede para o MP e/ou a PF investigarem e abrirem inquérito sobre determinada pessoa física ou jurídica.

Tabela 12. Classificação do Conteúdo dos Relatórios Finais das CPIs. (Acionamento de Instituições de Controle)

\begin{tabular}{|c|c|c|c|}
\hline ESTADO & $\begin{array}{c}\text { Relatórios que Acionam } \\
\text { o Ministério Público }\end{array}$ & $\begin{array}{c}\text { Relatórios que Acionam } \\
\text { a Polícia Federal }\end{array}$ & $\begin{array}{c}\text { Relatórios que Acionam } \\
\text { o Tribunal de Contas } \\
\text { Estadual }\end{array}$ \\
\hline DF & $66,66 \%(2)$ & $66,66 \%(2)$ & $66,66 \%(2)$ \\
\hline ES & $66,66 \%(2)$ & $0,0 \%$ & $0,0 \%$ \\
\hline GO & $40 \%(2)$ & $0,0 \%$ & $40 \%(2)$ \\
\hline MS & $100 \%(1)$ & $0,0 \%$ & $100 \%(1)$ \\
\hline MT & 0 & $0,0 \%$ & $0,0 \%$ \\
\hline PE & $100 \%(1)$ & $0,0 \%$ & $100 \%(1)$ \\
\hline RJ & $90 \%(9)$ & $30 \%(3)$ & $0,0 \%$ \\
\hline RO & $50 \%(1)$ & $0,0 \%$ & $50 \%(2)$ \\
\hline RS & $50 \%(2)$ & $0,0 \%$ & $21 \%(4)$ \\
\hline SP & $78,9 \%(15)$ & $5,2 \%(1)$ & $\mathbf{3 2 , 6 \% ( 1 6 )}$ \\
\hline TOTAIS (49) & $\mathbf{7 1 , 4 \% ( 3 5 )}$ & $\mathbf{1 2 , 2 \% ( 6 )}$ & \\
\hline
\end{tabular}

Fonte: Elaboração do Autor

Mesmo indiciando pouco, nominalmente, os investigados, a CPI solicita investigação deles para o MP, e 71,4\% delas encaminharam recomendações para o Ministério Público. Isso faz do Ministério Público a instituição mais acionada pelas Comissões Parlamentares de Inquérito. A explicação para esse protagonismo do Ministério Público deriva do reforço de suas atribuições conferidas pela Constituição de 1988, e assenta-se sobre sua atuação. É de considerável influência no combate à corrupção no país, responsável pela maior ativação dos tribunais nesses casos, sendo, sua principal marca, a independência institucional em relação aos outros órgãos do governo. Com efeito, ele é considerado a principal inovação no arcabouço institucional brasileiro, "entre as instituições brasileiras, essa talvez seja a mais singular [...] havendo ou não punição, uma conclusão se impõe: já não se pode mais afirmar que certos agentes públicos e grupos privilegiados estão inteiramente blindados. O Ministério Público tem contribuído para forçar rachaduras" (SADEK, 2008:543-549). 
No caso da responsabilização administrativa, repare-se que apenas 32,6\% dos relatórios analisados encaminham conclusões e pedidos de verificação de contas aos TCEs (Tribunais de Contas Estaduais). Essas recomendações podem vir sob a forma de encaminhamentos para investigações de determinado projeto em execução, ou nas contas de algum órgão da administração pública. Vale lembrar que o TCE é um órgão do próprio Poder Legislativo, que auxilia as Assembleias na fiscalização contábil e orçamentária.

\subsection{Comparando a CPI nos Diferentes Níveis Governamentais.}

Nessa seção, pretendemos comparar o desempenho das CPIs entre os diferentes níveis governamentais, ou seja, no nível Estadual e Federal. Em primeiro lugar, vale ressaltar que essa é uma comparação diacrônica e que não nos permite extrapolar as conclusões para a totalidade do sistema político brasileiro. Nosso objetivo é comparar os efeitos do desenho institucional em diferentes arenas legislativas, levando em conta as prerrogativas constitucionais das Comissões Parlamentares de Inquérito, bem como, o desempenho das CPIs nessas diferentes arenas.

Do ponto de vista das funções constitucionais das CPIs, encontramos, no marco regulatório delas, a comum função de poder de investigação sobre as ações do Executivo e o encaminhamento de um relatório final a outras instituições responsáveis em realizar: a) as mudanças na legislação e nas organizações (Executivo, Legislativo e Judiciário); b) as sanções administrativas (TCU, CGU e TCEs); e c) a responsabilização civil e criminal (MP, PF e indiciamentos). Outra semelhança que as CPIs, nessas arenas políticas, apresentam é no critério de composição das Comissões de Inquérito, ou seja, elas obedecem à proporcionalidade dos partidos no Plenário. Assim, o partido com maior número de cadeiras na Casa obterá a maior representação na comissão. Por isso, o partido majoritário tem maiores chances de ocupar os chamados postos-chave (presidência e relatoria) da comissão.

Os constrangimentos e incentivos institucionais para a instalação de CPIs correspondem a uma importante variável na mensuração da possibilidade de sucesso de uma Comissão Parlamentar de Inquérito. Quando olhamos para essas instituições, podemos destacar as diferenças no desenho institucional de estado para estado, como também entre as 
Assembleias Legislativas e o Congresso Nacional. Esses desenhos institucionais são responsáveis por criar constrangimentos ou incentivos à instalação de CPIs nos estados e na arena legislativa federal. Distribuindo os desenhos institucionais dos vinte estados trabalhados nesta dissertação e incluindo a União, obtemos o seguinte agrupamento.

\section{Quadro 8. Comparação entre os Diferentes Desenhos Institucionais: Assembleias}

\section{Estaduais e Congresso Nacional.}

\begin{tabular}{|c|c|c|c|}
\hline \multicolumn{4}{|c|}{ DESENHO INSTITUCIONAL } \\
\hline $\begin{array}{l}\text { Limitação Regimental do } \\
\text { Nume ro de CPIs em } \\
\text { andamento. }\end{array}$ & $\begin{array}{c}\text { Requisito de } \\
\text { Assinatura de 1/4 } \\
\text { dos Deputados via } \\
\text { Requerime nto }\end{array}$ & $\begin{array}{c}\text { Requisito de Assinatura de } \\
\text { 1/3 dos Deputados via } \\
\text { Reque rimento }\end{array}$ & $\begin{array}{c}\text { Requisito de } \\
\text { Assinatura de 1/3 } \\
\text { dos Deputados via } \\
\text { Requerimento + } \\
\text { Aprovação do } \\
\text { Plenário }\end{array}$ \\
\hline Limite de 7 CPIs Simultâneas & & Rio de Janeiro & \\
\hline Limite de 6 CPIs simultâneas & & Minas Gerais & \\
\hline Limite de 5 CPIs simultâneas & & $\begin{array}{c}\text { Bahia, Espírito Santo, } \\
\text { Maranhão, Pernambuco,União }\end{array}$ & Goiás, São Paulo \\
\hline Limite de 3 CPIs simultâneas & & Mato Grosso do Sul, Sergipe & Acre, Amapá \\
\hline Limite de 2 CPIs simultâneas & Ceará & & $\begin{array}{l}\text { Distrito } \\
\text { Federal,Tocantins }\end{array}$ \\
\hline $\begin{array}{l}\text { Sem Limitação Regimental no } \\
\text { Numero de CPIs simultâneas }\end{array}$ & & $\begin{array}{l}\text { Amazonas, Rio Grande do } \\
\text { Norte, Rio Grande do Sul }\end{array}$ & \\
\hline
\end{tabular}

Fonte: Elaboração do Autor

Se interpretarmos a tabela acima como um continuиm, em que uma extremidade corresponde ao regimento menos permissivo (-1) para a instalação de CPIs, e o outro extremo o mais permissivo (1) para a instalação das comissões, concluímos que o Distrito Federal e o Tocantins se localizam no extremo -1; Amazonas, Rio Grande do Norte e Rio Grande do Sul no extremo 1; já Bahia, Espírito Santo, Maranhão, Pernambuco e União, no nível intermediário, denominado de valor (0); os demais estados gravitam em torno do nível intermediário, como Goiás, São Paulo, Acre e Amapá, pendendo para o extremo -1, e Ceará, Rio de Janeiro, Minas Gerais, Mato Grosso do Sul e Sergipe, aproximando-se do extremo 1. 
Assim, quando comparamos as médias anuais de CPIs instaladas na União e nos estados, levando em conta suas diferenças institucionais e de intervalo de amostra, obtemos, de acordo com os dados de Cadah et alii (2012), uma média anual de 4 CPIs instaladas por ano no plano federal. Já em nível subnacional, ao desagregarmos o número de CPIs instaladas, de acordo com o nível de permissividade institucional na instalação de Comissões de Inquérito, obtém-se, para os estados com regimentos permissivos, uma média de 5 CPIs instaladas ao ano (com destaque para o Rio de Janeiro, com um total de 12 CPIs instaladas). Para aqueles estados que se assemelham ao desenho institucional do plano federal, temos uma média de 3 CPIs instaladas ao ano; por fim, nos estados com níveis baixos de permissividade, temos uma média de 11 CPIs instaladas ao ano, com destaque para São Paulo que, nesse período, teve 20 CPIs, no total.

Levando em conta a diferença da amostra utilizada e o contexto de cada arena política, podemos inferir (embora de maneira parcimoniosa ${ }^{8}$,) que desenho institucional, aqui entendido como o Regimento Interno das Casas Legislativas analisadas, não é uma condição suficiente para explicar as diferentes taxas de instalação das Comissões Parlamentares de Inquérito nos estados, ao detectarmos que os estados com desenhos institucionais mais restritivos à instalação de CPIs foram aqueles que apresentaram as maiores médias anuais de comissões instaladas ao ano. Portanto, os dados encontrados restringem a capacidade explicativa da segunda hipótese de pesquisa desta dissertação, que define que é o desenho institucional das casas legislativas que explica a variação da ocorrência de CPIs: quanto maiores os constrangimentos regimentais para instalação de CPIs, menor a ocorrência dessas comissões nos diferentes estados.

Outro elemento comparativo que apresenta diferenças importantes é a posição política em relação ao binômio governo x oposição dos autores das CPIs instaladas. Como pode ser observado nos números presentes no trabalho de Cadah et alii (2012), 62\% (63) de um total de 101 das CPIs instaladas no período de 1988-2010 tiveram autoria de membros da oposição. Já nas unidades subnacionais, podemos observar que 74,24\% (49) das CPIs instaladas tiveram autoria de membros da base do governo, contra 25,76\% (17) de autoria de parlamentares da oposição. Assim, em termos comparativos, na arena federal, a oposição é mais proativa na iniciativa para instalar CPIs, já que a maioria dos autores das Comissões de Inquérito instaladas no período 1988-2010 eram membros da oposição, enquanto que, nas

\footnotetext{
${ }^{8}$ Dado que as amostras utilizadas no argumento apresentam uma diferença substancial em seus intervalos, sendo a amostra do plano federal de 22 anos e, nos estados, de 3 anos.
} 
unidades subnacionais, os números revelam um cenário diferente, no qual os membros da base do governo se sobrepõem à oposição na autoria das CPIs instaladas

Outra dimensão fundamental para a comparação proposta é a ocupação de postoschave, durante a formação das CPIs, que correspondem à presidência e à relatoria da comissão e indicam o grupo que terá o controle sobre o processo investigativo. Notamos muitas semelhanças nos percentuais encontrados nos dados para as unidades subnacionais e para o plano federal.

Em nível federal, os dados de Cadah et alii (2011) apontam que a base governista ocupou os dois cargos mais importantes (presidência e relatoria) em 70\% das CPIs instaladas nas Casas Legislativas, e em 30\%, a oposição apresenta participação efetiva na comissão, comandando um dos dois postos (vale destacar que, entre esses 30\%, em apenas $10 \%$ ela controlou os dois postos-chave ${ }^{9}$ ). Analisando as unidades subnacionais, os números não diferem muito, pois a base governista ocupou, em 83,33\% das comissões, a presidência, e, em 60,60\%, a relatoria. Nas CPIs estaduais criadas exclusivamente para fiscalizar as ações do executivo, os números se distanciam ainda mais, já que membros da base governista ocuparam $84,6 \%$ da presidência e $70 \%$ da relatoria.

Tabela 13. Conclusão dos Relatórios Finais das CPIs nos Legislativos Estaduais Federal.

\begin{tabular}{|c|c|c|}
\hline $\begin{array}{c}\text { Tipo de Conclusão e Instituições } \\
\text { acionadas nos Relatórios Finais }\end{array}$ & $\begin{array}{c}\text { Relatórios Finais: CPIs } \\
\text { Congresso Nacional } \\
\text { (Câmara dos Deputados, } \\
\text { Senado e Mistas) } \\
\text { 1999-2010 (\%) }\end{array}$ & $\begin{array}{c}\text { Relatórios Finais: } \\
\text { Assembléias Legislativas } \\
\text { Estaduais na Legislatura } \\
\mathbf{2 0 0 7 - 2 0 1 0}(\mathbf{\%})\end{array}$ \\
\hline Executivo & 90,7 & 75,5 \\
\hline Legislativo & 79,1 & 75,5 \\
\hline Judiciário & 46,5 & 16,3 \\
\hline Ministério Público & 86,0 & 71,4 \\
\hline Tribunal de Contas & 51,2 & 32,6 \\
\hline Polícia Federal & 55,8 & 12,2 \\
\hline Propõe PL e alteração em Legislação & 74,4 & 28,6 \\
\hline Aciona Indiciamento & 41,9 & 8,1 \\
\hline
\end{tabular}

Fonte: Elaboração do Autor

\footnotetext{
9 Isso ocorreu em oito CPIs de vinte e três instaladas no governo Collor e em 2 das 17 instaladas no primeiro mandato do presidente Lula.
} 
Inicialmente, a tipologia foi elaborada com base nas CPIs do plano federal ${ }^{10} \mathrm{e}$ podemos aplicar as mesmas variáveis para a esfera estadual, a partir dos dados agregados. A primeira observação relevante é a de que o desempenho do Congresso Nacional é superior em todas as categorias de nossa tipologia quando observado em comparação ao desempenho das Assembleias Legislativas. Enquanto os deputados federais e senadores propuseram projetos de lei e alterações na legislação vigente, em 74,4\% das CPIs concluídas, apenas 28,6\% das CPIs, na esfera estadual, continham conclusões propriamente legislativas. Esse achado deve ser lido com atenção, uma vez que as possibilidades constitucionais de legislar são maiores no Congresso Nacional em relação à Assembleia Legislativa. Mais da metade das CPIs concluídas nas duas Casas do Congresso Nacional realizaram encaminhamentos ao Tribunal de Contas da União; em contrapartida, apenas 32,6\% das CPIs, nas Assembleias Legislativas, continham, em seus relatórios finais, encaminhamento aos Tribunais de Contas dos estados. A diferença aparece com mais força quando comparamos a taxa de responsabilização via indiciamento: enquanto os relatórios finais de CPIs, no Legislativo Federal, produziram indiciamentos em $41,9 \%$ do total de CPIs analisadas, apenas 8,1\% das CPIs, no Legislativo Estadual, utilizaram-se desse expediente nos relatórios finais.

Quando comparamos o desempenho das CPIs dos Legislativos Estaduais brasileiros com o Legislativo Federal, obtemos parâmetro para analisar, em perspectiva comparada, esses resultados. ${ }^{11} \mathrm{O}$ desempenho do Congresso Nacional é superior em todas as categorias de nossa tipologia quando observado em comparação ao desempenho das Assembleias Legislativas. Enquanto os deputados federais e senadores propuseram projetos de lei e alterações em pontos específicos da legislação vigente em 74,4\% das CPIs instaladas e concluídas, apenas $28,6 \%$ das CPIs, na esfera estadual, continham conclusões propriamente legislativas. A diferença aparece com mais força quando comparamos a taxa de acionamento de responsabilização via indiciamento: enquanto os relatórios finais de CPIs no Legislativo Federal produziram indiciamentos em $41,9 \%$ do total de CPIs analisadas, apenas $8,1 \%$ das CPIs do Legislativo Estadual utilizaram-se desse expediente nos relatórios finais.

\footnotetext{
${ }^{10}$ A classificação do desempenho das CPIs no Congresso Nacional foi realizada pelo autor em parceria com Lucas Queija Cadah, no âmbito do projeto realizado pelo NUPPS, em parceria com a FKA: O Desempenho do Congresso Nacional no contexto do Presidencialismo de Coalizão.

${ }^{11}$ A classificação do desempenho das CPIs no Congresso Nacional foi realizada pelo autor em parceria com Lucas Queija Cadah, no âmbito do projeto realizado pelo NUPPS, em parceria com a FKA: O Desempenho do Congresso Nacional no contexto do Presidencialismo de Coalizão.
} 
Uma hipótese plausível para analisar os dados e, centralmente, a diferença no desempenho das CPIs federais e estaduais é o comportamento estratégico dos deputados estaduais em uma arena propícia à cooperação com o Executivo. O comportamento do Legislativo ocorre em acordo com o Executivo porque esse comportamento é racionalmente mais rentável para manter e potencializar suas carreiras políticas. Segundo a literatura (ABRUCIO et all), o deputado estadual enxerga a Assembleia como instituição de passagem, e unicamente como canal de acesso às verbas do governador, com vias a progredir na carreira como deputado federal ou prefeito. Justamente por depender do acesso a cargos e emendas ao orçamento que o comportamento cooperativo de deputado estadual frente ao Executivo enfraquece a dimensão de fiscalização e controle.

Em contrapartida, os deputados federais, apesar de dependerem do Executivo Federal para obtenção de recursos - emendas, cargos etc. - a fim de atender suas bases eleitorais, não estão presos unicamente aos recursos advindos do Executivo Federal. Isso porque a estrutura federalista do sistema político brasileiro possibilita manter relacionamento com os Executivos subnacionais, que também podem lhes oferecer recursos políticos que lhes garantam contato com suas bases eleitorais ${ }^{12}$. Fato que não ocorre com os deputados estaduais, cujo contato com o Executivo federal é mais custoso e a relação com os prefeitos é de competição por espaço político.

Outro elemento explicativo para as diferenças no desempenho das duas arenas é a capacidade de mobilização da sociedade civil, ou seja, a capacidade que as comissões têm de ativar "alarmes de incêndio", isto é, a capacidade que as minorias apresentam na mobilização da sociedade civil - mídia, grupos organizados etc. - pode afetar o desempenho que uma CPI apresenta na condução e na conclusão dos seus trabalhos, pressupondo que esse elemento difira, em grau de intensidade, do plano subnacional para o nacional, isto é, a cobertura via imprensa é muito maior no Congresso Nacional do que nas Assembleias Legislativas, o que provoca maior mobilização social nas CPIs federais que estaduais. Esse fato gera mais constrangimentos no se refere a resultados insatisfatórios ${ }^{13}$ nas Comissões de Inquérito federais do que na arena estadual, porque a chamada dimensão vertical da accountability é mais ativa no plano federal do que no estadual.

\footnotetext{
${ }^{12}$ Aparição em inaugurações de obras, cargos de confiança a pessoas ligadas ao deputado federal em autarquias e secretarias, emendas informais etc.

${ }^{13}$ Não conclusão dos trabalhos ou não acionamento de outras instituições de controle.
} 
Portanto, observamos, ao longo das demonstrações comparativas entre o plano federal e as unidades subnacionais, as semelhanças e as diferenças existentes entre os elementos que envolvem a dimensão da aprovação, instalação e composição de uma CPI e podemos indicar, com base nos dados trabalhados, que a oposição encontra mais espaço para instalar CPIs do que para controlar o processo investigativo das comissões através da ocupação de cargos estratégicos, como presidência e relatoria, decorrência natural em um sistema legislativo que privilegia o grupo político majoritário. No entanto, não se pode afirmar que a CPI não seja uma arma para as minorias, que, ao conseguirem instalar uma comissão, consequentemente, ativam o que Figueiredo (2002) chama de "Alarmes de Incêndio", chamando a atenção para outros mecanismos de accountability, tanto horizontal como vertical ${ }^{14}$.

\footnotetext{
${ }^{14}$ Ativa a atenção de outros órgãos de controle governamental e chama atenção do eleitorado e de grupos sociais organizados.
} 


\section{CAPÍTULO V - ESTUDO DE CASOS: ANÁLISE DE DEZ RELATÓRIOS FINAIS DAS CPIS NAS ASSEMBLEIAS LEGISLATIVAS.}

\subsection{Introdução}

Este capítulo tem como objetivo geral descrever e analisar os dez relatórios finais de um total de treze CPIs ${ }^{15}$ que visavam investigar os Executivos Estaduais (variável Investgov). Especificamente, pretende descrever e analisar a dinâmica política desenvolvida nas comissões, principalmente no jogo travado entre governo e oposição, através de suas estratégias, interesses e, centralmente, como esses atores agem na arena política para satisfazer seus objetivos individuais e coletivos.

Dos vinte estados contidos na amostra desta dissertação, apenas cinco apresentaram a instalação e a conclusão deste tipo de CPI (Investgov) como objetivo de fiscalizar o executivo estadual. São estes:

Quadro 9. CPIs com Objetivo de Investigar o Governo Estadual.

\begin{tabular}{|c|c|}
\hline ESTADO & CPI \\
\hline Distrito Federal & Cemitérios, Gautama, Codeplan \\
\hline Goiás & CELG, Endividamento e Saúde \\
\hline Mato Grosso & SEMA \\
\hline Rio Grande do Sul & Polo dos Pedágios, Corrupção e DETRAN \\
\hline São Paulo & Eletropaulo e CDHU \\
\hline Tocantins & Saúde \\
\hline
\end{tabular}

Fonte: Elaboração do Autor

O material analisado corresponde aos relatórios finais de dez das treze CPIs. O foco está na ocupação dos postos-chave (presidência e relatoria) da comissão, na origem da apresentação de requerimento e na aceitação ou não deles. Por fim, pretende-se verificar o tipo de resultado que a comissão apresentou, ou seja, verificar as instituições acionadas pela

\footnotetext{
${ }^{15}$ A quantidade de relatórios é inferior ao número de CPIs, pois o relatório final da CPI da Saúde instalada no Tocantins e o da CPI da CODEPLAN no Distrito Federal não foram disponibilizados.
} 
comissão e qual o tipo de acionamento e indicações para essas instituições houve por parte das Comissões de Inquérito. Em primeiro lugar, apresentamos o contexto político do estado e, em seguida, analisamos os desdobramentos de cada CPI aqui discutida.

\subsection{Estado de Goiás}

No período analisado, o estado de Goiás foi governado por Alcides Rodrigues Filho (2006-2010), do Partido Progressista (PP), que mantinha uma coalizão de governo formada por nove partidos: PSDB, PR, PTB, PP, PT do B, PSB, DEM, PDT e PSC. Nessa Legislatura (2007 - 2010), o governador construiu uma coalizão governista com 70,7\% dos deputados da Assembleia Legislativa.

\section{a) CPI da CELG}

Essa CPI foi instalada no ano de 2009, com objetivo de investigar possíveis irregularidades financeiras na CELG (Companhia Energética de Goiás), eventual causa do endividamento da companhia, no intervalo temporal de vinte e cinco anos (198-2010). Essa Comissão de Inquérito foi composta pelos seguintes deputados:

\section{Quadro 10. Composição e Distribuição dos Cargos da CPI da CELG}

\begin{tabular}{|c|c|}
\hline TITULARES & PARTIDO \\
\hline Dep. Hélio de Souza (Presidente) & DEM \\
\hline Dep. Coronel Queiroz (Vice - Presidente) & PTB \\
\hline Dep. Humberto Haidar (Relator) & PT \\
\hline Dep. Daniel Goulart & PSDB \\
\hline Dep. José Neto & PMDB \\
\hline
\end{tabular}

Fonte: Elaboração do Autor

Observando a composição da CPI, notamos que, dentre os deputados titulares, três são da base do governo (PTB, PSDB e DEM) e dois são da oposição (PT, PMDB). Já em relação aos postos de presidência e relatoria, notamos que a base governista ficou com dois 
cargos importantes: a presidência, com o deputado Hélio de Souza, do DEM, e a vicepresidência, com o deputado Coronel Queiroz, do PTB; a oposição, no entanto, ficou com o cargo de relator da comissão, posto ocupado pelo deputado Humberto Haidar, do PT. Portanto, a base governista não conseguiu controlar completamente a distribuição dos postoschave, já que o cargo responsável pela elaboração do relatório final ficou com o PT, principal partido de oposição ao governador.

Outro elemento importante na compreensão da dinâmica das CPIs corresponde à análise dos requerimentos ${ }^{16}$. De início, vale dar destaque aos autores dos requerimentos e, por conseguinte, ao conteúdo deles..

\footnotetext{
${ }^{16}$ Instrumento regimental das CPIs responsáveis por convocar testemunhas e suspeitos, além de requisitar documentos, quebras de sigilo bancário etc.
} 
Quadro 11. Requerimentos Apresentados na CPI da CELG

\begin{tabular}{|c|c|c|c|}
\hline AUTOR & $\begin{array}{l}\text { GOVERNO/ } \\
\text { OPOSIÇÃO }\end{array}$ & $\begin{array}{l}\text { PRINCIPAL OBJETIVO DO } \\
\text { REQUERIMENTO }\end{array}$ & $\begin{array}{l}\text { PARECER } \\
\text { DA MESA }\end{array}$ \\
\hline $\begin{array}{l}\text { José Nelto e } \\
\text { Samuel Belchior }\end{array}$ & Oposição & $\begin{array}{c}\text { Apresentação documentos fiscais da CELG e } \\
\text { Convocação de Todos Ex Presidentes da Instituição. }\end{array}$ & Aprovado \\
\hline Daniel Goulart & Governo & $\begin{array}{c}\text { Solicita Quebra de Sigilo Bancário dos Governadores } \\
\text { e Diretores da CELG de } 1994 \text { e } 1995 .\end{array}$ & Aprovado \\
\hline Daniel Goulart & Governo & $\begin{array}{c}\text { Solicita o Relatório de Avaliação Econômico - } \\
\text { Financeiro da Companhia. }\end{array}$ & Aprovado \\
\hline Daniel Goulart & Governo & $\begin{array}{l}\text { Solicita ao Procurador Geral de Justiça o envio de } \\
\text { documentos. }\end{array}$ & Aprovado \\
\hline José Nelto & Oposição & $\begin{array}{c}\text { Convocação de Janildes de Souza Fernandes para } \\
\text { esclarecer desvios da CELG para Prefeitura de } \\
\text { Goiânia }\end{array}$ & Aprovado \\
\hline Daniel Goulart & Governo & $\begin{array}{l}\text { Solicita todos os contratos da CELG com Pequenas } \\
\text { Hidrelétricas e com o Governo Federal nos últimos } \\
\qquad 25 \text { anos. }\end{array}$ & Aprovado \\
\hline José Nelto & Oposição & Convoca o Advogado que prestou serviço a CELG. & Aprovado \\
\hline Daniel Goulart & Governo & $\begin{array}{c}\text { Convoca o Ex Prefeito e atual Prefeita do Município } \\
\text { de Santa Helena que manteve contratos com a } \\
\text { CELG. }\end{array}$ & Rejeitado \\
\hline Humberto Haidar & Oposição & $\begin{array}{c}\text { Solicita ao Presidente da CELG, cópias dos contratos } \\
\text { entre a Companhia e a Empresa Hotline. }\end{array}$ & Aprovado \\
\hline Coronel Queiroz & Governo & Solicita os contratos entre a CELG e 23 Municípios. & Aprovado \\
\hline José Nelto & Oposição & $\begin{array}{c}\text { Solicita o Presidente da CELG que Informe o Valor } \\
\text { da Obra da Usina de Cachoeira. }\end{array}$ & Aprovado \\
\hline Daniel Goulart & Governo & $\begin{array}{c}\text { Convite ao Presidente da Eletrobrás e para o Ministro } \\
\text { Edson Lobão. }\end{array}$ & Aprovado \\
\hline $\begin{array}{l}\text { José Nelto e } \\
\text { Humberto Haidar }\end{array}$ & Oposição & $\begin{array}{c}\text { Solicita ao Presidente da CELG cópias de todos os } \\
\text { contratos com empresas terceiras. }\end{array}$ & Aprovado \\
\hline Humberto Haidar & Oposição & $\begin{array}{c}\text { Solicita ao Presidente da CELG os contratos da } \\
\text { SEBIL. }\end{array}$ & Aprovado \\
\hline José Nelto & Oposição & $\begin{array}{l}\text { Solicita a Quebra de Sigilo Bancário, Fiscal e } \\
\text { Telefônico dos diretores da empresa Evolutti. }\end{array}$ & Aprovado \\
\hline José Nelto & Oposição & $\begin{array}{c}\text { Solicita Cópias dos Contratos da CELG com Endesa } \\
\text { Cachoeira Dourada e a Empresa } 212 .\end{array}$ & Aprovado \\
\hline José Nelto & Oposição & $\begin{array}{c}\text { Solicita Cópias dos Contratos entre a CELG e a } \\
\text { Empresa ERP - SAP. }\end{array}$ & Aprovado \\
\hline Daniel Goulart & Governo & $\begin{array}{l}\text { Solicita ao Presidente da ANEEL os Lucros e os } \\
\text { Dividendos do lucro da Usina Cachoeira Dourada. }\end{array}$ & Aprovado \\
\hline
\end{tabular}

Fonte: Elaboração do Autor 
A tabela acima nos mostra que os pedidos de requerimentos se equilibram entre Oposição e Governo, já que o primeiro apresentou dez pedidos contra oito do segundo. No que se refere ao número de pedidos rejeitados pela Mesa, notamos um valor muito baixo, pois, de 18 pedidos realizados, apenas um foi rejeitado, os 17 restantes foram aceitos. Em relação ao conteúdo deles, podemos afirmar que apresentaram nítido objetivo de investigação sobre o Executivo. Essa CPI apresenta um traço peculiar, já que o foco de sua investigação não foi dirigido apenas à investigação do Executivo situacionista, mas, também, aos últimos vinte e cinco anos do Governo do Estado de Goiás (provavelmente, por esse motivo, governo e oposição se equilibrem quanto ao número de requerimentos efetuados na comissão).

Em relação ao acionamento de outras instituições, notamos que essa CPI fez recomendações ao Governo do Estado de Goiás, à Diretoria da CELG, ao Ministério Público do Estado de Goiás e, também, ao Tribunal de Contas do Estado. Em relação à primeira instituição, acima citada, a CPI exigiu a apresentação de documentos que justificassem os motivos pelos quais não foi contabilizada a dívida do Estado de Goiás com a CELG; já à segunda, foram feitas recomendações para que ela reavaliasse os critérios na contratação de empresas terceirizadas, para otimizar os serviços e adequá-los ao estatuto; ao Ministério Público foi feito o pedido de indiciamento (responsabilização civil criminal) dos infratores, além do aprofundamento do processo investigativo; e, por fim, foi pedido ao Tribunal de Contas que realizasse inspeções e auditorias nos fatos apresentados pela CPI.

Notamos, portanto, que a CPI da CELG realizou sua tarefa posta pela Constituição, levando em conta que desenvolveu um trabalho investigativo sobre as ações do Executivo, procurando apurar todos os fatos através da análise de documentos, da consulta de testemunhas e de supostos acusados, além de acionar, no fim de seus trabalhos, as instituições responsáveis por dar continuidade ao processo de responsabilização civil/criminal, reforma administrativa etc.

\section{b) CPI do Endividamento}

Essa CPI foi instalada em 2010, com o objetivo de investigar as causas do endividamento do estado de Goiás, que ocorreu no período que vai de 1991 a 2009. Essa Comissão de Inquérito foi composta pelos seguintes deputados: 


\section{Quadro 12. Composição e Distribuição dos Cargos na CPI do Endividamento}

\begin{tabular}{|c|c|}
\hline TITULARES & PARTIDO \\
\hline Dep. Claudio Meirelles (Presidente) & PR \\
\hline Dep. Mauro Rubem (Vice - Presidente) & PT \\
\hline Dep. Honor Cruvinel (Relator) & PSDB \\
\hline Dep. Marlúcio Pereira & PTB \\
\hline Wellington Valim & PT do B \\
\hline
\end{tabular}

Fonte: Elaboração do Autor

Observando a composição da CPI, notamos que, dentre os deputados titulares, quatro são da base do governo (PR, PSDB, PTB e PT do B) e apenas um da oposição (PT). Em relação aos postos-chave, a base governista detém os dois principais cargos: a presidência, com deputado Claudio Meirelles, do PR, e a relatoria, com o deputado Honor Cruvinel, do PSDB.

Em relação aos requerimentos, essa CPI não apresentou um volume grande; a maioria deles não demonstrava conteúdo investigativo, mas, sim, trâmites burocráticos para o andamento da CPI. Assim, para compreender melhor a dinâmica dela, foi analisado o conteúdo das reuniões. Primeiramente, essa CPI não apresentou um trabalho investigativo minucioso, visto que, basicamente, limitou-se à análise do Relatório do TCE sobre o balanço financeiro do estado no período em questão, deixando de analisar documentos relevantes e de ouvir pessoas importantes para o processo investigativo, como a não convocação de todos os governadores que exerceram mandato durante o período investigado.

Em relação às conclusões do relatório, primeiro, vale salientar que elas foram baseadas, estritamente, no já referido relatório do TCE, com a análise da consultora FIPE (Fundação Instituto de Pesquisas Econômicas); segundo, que a comissão não encaminhou recomendações ou diretrizes a outras instituições de controle; e, terceiro, que as conclusões sobre o endividamento apontam a seguinte lógica: o crescimento da dívida do Estado de Goiás ocorre no período 31.12.1990 a 31.12.1998, nos Governos de Íris Rezende e Maguito Vilela, ambos do PMDB. Nas gestões que vão de 31.12.1998 a 31.12. 2005, que correspondem aos dois mandatos de Marconi Perillo, as dívidas diminuem; mas voltam a aumentar na gestão de Alcides Rodrigues, em especial no ano de 2009. Analisando o trabalho investigativo dessa CPI, podemos afirmar que seus resultados não foram satisfatórios, considerando que ela não encaminhou nenhuma recomendação a outras instituições e limitou 
sua investigação ao relatório do TCE, deixando de fora elementos importantes ${ }^{17}$ para o processo investigatório.

\section{c) CPI da Saúde}

Essa CPI foi instalada em 2008, com o objetivo de investigar o cumprimento, pelo Poder Executivo, do Artigo 198 da Constituição Federal, no que tange à aplicação constitucional dos recursos (12\% do orçamento) para a saúde pública no estado de Goiás, nos exercícios de 2001, 2002 e 2003, durante o governo Marconi Perillo.

Antes de analisar, especificamente, o trabalho dessa comissão, vale destacar o momento de sua instalação e o conflito político que se delineou. Primeiramente, essa CPI é fruto de um requerimento, derrotado em plenário, realizado pelos deputados do PT, Mauro Rubem, Humberto Aidar e Luís César Bueno, em 22.05.2007. Na ocasião, a Mesa Diretora da Assembleia descumpriu o regimento e não realizou a leitura do requerimento no Plenário da Casa, antes da votação. A bancada do PT buscou o Judiciário mostrando a irregularidade cometida pela Mesa na votação do requerimento da CPI e apontou as ressalvas do TCE que mostravam o descumprimento da Constituição, na execução do orçamento por parte do Executivo do estado de Goiás, nos anos de 2001-2003, no que se referia à não aplicação dos recursos destinados à Saúde. O Poder Judiciário acatou o pedido do PT e instalou, por força judicial, a CPI da Saúde.

Após sua instalação, outros entraves políticos emergiram e impediram o andamento dos trabalhos da comissão. Os deputados titulares Valdir Bastos (PR), Wellington Valin (PT do B) e Helder Valin (PSDB) faltaram, sem justificativa, às quatro primeiras reuniões da comissão, sendo substituídos pelos deputados Evandro Magal, Júlio da Retífica e Carlos Silva, viabilizando o trabalho da CPI apenas em março de 2009, com a escolha de presidente, vice-presidente e relator. Assim, ficou a composição da comissão:

\footnotetext{
${ }^{17}$ Refiro-me à maior quantidade de documentos, à convocação para depoimento de pessoas importantes para a investigação e etc.
} 


\section{Quadro 13. Composição e Distribuição dos Cargos na CPI da Saúde}

\begin{tabular}{|c|c|}
\hline TITULARES & PARTIDO \\
\hline Dep. Carlos Silva (Presidente) & PP \\
\hline Dep. Adriete Elias (Vice-Presidente) & PMDB \\
\hline Dep. Mauro Rubem (Relator) & PT \\
\hline Dep. Evandro Magal & PP \\
\hline Dep. Júlio da Retífica & PSDB \\
\hline
\end{tabular}

\section{Fonte: Elaboração do Autor}

Observando a composição da CPI, notamos que, dentre os deputados titulares, três são da base do governo (PP, PSDB) e dois são da oposição (PMDB e PT). Em relação aos postos-chave, o governo ficou com a presidência e a oposição com a relatoria. No que diz respeito ao processo investigativo da CPI, notamos a elaboração de um trabalho detalhado, no qual foi feita a análise dos relatórios do TCE sobre os gastos do estado de Goiás com a Saúde, comparando-os com os relatórios enviados pelo estado de Goiás ao Sistema de Informações sobre o Orçamento Público em Saúde (SIOPS). Também foi realizada a análise de documentos e a convocação de pessoas relevantes ao processo investigativo, além das visitas de membros da comissão às unidades de saúde do estado de Goiás.

Como conclusão desse trabalho, a CPI emite o seguinte parecer:

Analisando profundamente os dados que compõem o presente relatório, concluímos que o Estado de Goiás descumpriu o preceito legal e constitucional que determina a aplicação dos $12 \%$ da receita líquida em ações e serviços de Saúde, tanto pela análise do Balanço Geral do Estado do TCE, como pela análise do SIOPS. Além desta Irregularidade, o estado deixou de enviar os gastos com saúde ao SIOPS no período de 2001 a 2003. Diante de tudo isso, pode afirmar que deixou de ser aplicado no período aproximadamente $20 \%$ do valor total que o estado deveria investir em Saúde nestes anos" (Relatório CPI da Saúde, Pag. 42).

Mediante essa conclusão, a CPI elabora as recomendações aciona as seguintes instituições:

“a) Este relatório seja encaminhado ao Ministério Público Estadual, para investigar a não aplicação dos recursos próprios em saúde, conforme EC 29 de 13/09/2000; 
b) Seja informado ao SIOPS que existem diferenças entre os dados levantados e o relatório financeiro do TCE, quanto às contas do Governo do Estado de Goiás, conforme aqui apurado [...]

[...] d) Sejam encaminhadas cópias deste relatório ao Ministério da Saúde, ao Tribunal de Contas da União e ao Tribunal de Contas do Estado, à Associação Goiana de Municípios e a todos os membros do Conselho Estadual de Saúde;

e) "Seja dada ampla divulgação dos resultados aqui alcançados a toda população goiana” (Relatório CPI da Saúde, Pag. 47).

Podemos, portanto, observar a tensa dinâmica política nessa CPI. Primeiro, pela dificuldade da sua instalação e pela tentativa do governo de travar o andamento da CPI com intuito de arquivá-la ${ }^{18}$; segundo, pelo fato de a base governista ter perdido o controle da CPI, já que, após tentativas frustradas de impedir seu andamento, abriu espaços para a oposição, que ocupou a relatoria e, usando as prerrogativas do cargo, conseguiu promover processo investigativo com resultados contundentes em relação às infrações cometidas pelo Executivo.

\subsection{Estado de São Paulo}

No ano período analisado, o estado de São Paulo foi governado por José Serra, do Partido Social Democrático Brasileiro (PSDB) e mantinha uma coalizão de governo formada por onze partidos: o PSDB, DEM, PPS, PTB, PSC, PP, PV, PDT, PR, PSB e PMDB, e tinha como oposição o PT, PC do B e o PSOL. Na Legislatura 2007-2010, o governador construiu uma coalizão governista com 76,6\% dos deputados da Assembleia Legislativa.

\section{a) CPI da CDHU}

Essa CPI foi instalada em 2009, através do requerimento 1.506 do deputado Mário Reali (PT), com o objetivo de investigar as denúncias do jornal Folha de São Paulo sobre possíveis fraudes nos processos de licitação envolvendo a construção de casas populares Habiteto - desenvolvido pela Companhia de Desenvolvimento Habitacional e Urbano (CDHU). Essa Comissão de Inquérito foi composta pelos seguintes deputados:

\footnotetext{
${ }^{18}$ Através da faltas, as reuniões da CPI, dos membros titulares ligados à base governista.
} 
Quadro 14. Composição e Distribuição dos Cargos da CPI da CDHU

\begin{tabular}{|c|c|}
\hline TITULARES & PARTIDO \\
\hline Dep. José Augusto (Presidente) & PSDB \\
\hline Dep. Milton Flávio (Vice - Presidente) & PSDB \\
\hline Dep. Roberto Morais (Relator) & PPS \\
\hline Dep. Ênio Tatto & PT \\
\hline Dep. Antonio Mentor & PT \\
\hline Dep. Eli Corrêa Filho & DEM \\
\hline Dep. Chico Sardelli & PV \\
\hline Dep. Roque Barbieri & PTB \\
\hline Dep. Bruno Covas & PSDB \\
\hline
\end{tabular}

Fonte: Elaboração do Autor

Observamos no quadro acima que o governo apresenta uma grande maioria nesta comissão, com sete cadeiras contra apenas duas da oposição. Um aspecto importante é o domínio da base governista sobre todos os postos-chave, pois, como mostram os dados, a situação fica com a presidência através do Deputado José Augusto, do PSDB, com a vice presidência cargo ocupado pelo deputado Milton Flávio, também do PSDB, e o cargo de relator fica com o deputado Roberto Morais, do PPS. O governo, portanto, ocupou todos os principais cargos capazes de influenciar diretamente os rumos da CPI.

A força política da base governista na comissão é demonstrada ao longo dos trabalhos da CPI. Isso se evidencia nos requerimentos com conteúdo investigativo. 
Quadro 15. Requerimentos Apresentados na CPI da CDHU

\begin{tabular}{|c|c|c|c|}
\hline AUTOR & $\begin{array}{l}\text { GOVERNO/ } \\
\text { OPOSIÇÃO }\end{array}$ & CONTEÚDO DO REQUERIMENTO & RESULTADO \\
\hline $\begin{array}{l}\text { Mentor (PT) e } \\
\text { Tatto (PT) }\end{array}$ & Oposição & Convocação do Presidente do TCE & Rejeitado \\
\hline $\begin{array}{l}\text { Mentor }(\mathrm{PT}) \text { e } \\
\text { Tatto (PT) }\end{array}$ & Oposição & $\begin{array}{c}\text { Convocação do Promotor da Comarca de } \\
\text { Pirapozinho }\end{array}$ & Rejeitado \\
\hline $\begin{array}{l}\text { Mentor }(\mathrm{PT}) \text { e } \\
\text { Tatto (PT) }\end{array}$ & Oposição & Convocação do Delegado da Polícia Civil & Rejeitado \\
\hline $\begin{array}{l}\text { Mentor }(\mathrm{PT}) \text { e } \\
\text { Tatto (PT) }\end{array}$ & Oposição & $\begin{array}{c}\text { Disponibilização da documentação entregue } \\
\text { pelo ex Presidente da CDHU }\end{array}$ & Rejeitado \\
\hline Tatto (PT) & Oposição & $\begin{array}{l}\text { Convite à representante do fórum Moradia e } \\
\text { Meio Ambiente de SP }\end{array}$ & Rejeitado \\
\hline $\begin{array}{l}\text { Mentor (PT) e } \\
\text { Tatto (PT) }\end{array}$ & Oposição & Convocação do Presidente da CDHU & Rejeitado \\
\hline Tatto (PT) & Oposição & $\begin{array}{c}\text { Convite à representante da Frente de Luta por } \\
\text { Moradia de SP }\end{array}$ & Rejeitado \\
\hline Tatto (PT) & Oposição & Convocação do ex Presidente da CDHU & Rejeitado \\
\hline $\begin{array}{c}\text { Mentor (PT) e } \\
\text { Tatto (PT) }\end{array}$ & Oposição & $\begin{array}{c}\text { Convocação do responsável pela empresa de } \\
\text { Engenharia }\end{array}$ & Rejeitado \\
\hline
\end{tabular}

Fonte: Elaboração do Autor

Primeiramente, observamos, nos dados acima, que todos os requerimentos rejeitados foram apresentados por deputados da oposição, e vale notar que, dos nove requerimentos, pelo menos sete eram de fundamental importância para o trabalho de investigação elaborado pela CPI, como, por exemplo, a convocação do presidente do TCE etc. A base governista se valeu da posição estratégica que apresentava na CPI, não com a finalidade de impedir os trabalhos, mas, sim, de proteger o governo de uma investigação minuciosa que poderia acarretar descobertas sobre possíveis atos de infração que feririam a imagem do governo.

Entre as providências tomadas, não houve nenhum encaminhamento ao Ministério Público para abertura de investigação sobre membros do alto escalão do governo. Encaminharam apenas penalidades a funcionários de baixo escalão da prefeitura e das empresas envolvidas no processo de licitação. 


\section{b) CPI da Eletropaulo}

Essa CPI foi instalada em 2007 com o objetivo de investigar possíveis irregularidades no processo de venda do controle acionário da Eletropaulo Metropolitana Eletricidade de São Paulo S.A através do requerimento 360/2007 do deputado Antônio Mentor (PT). Essa Comissão de Inquérito foi composta pelos seguintes deputados:

Quadro 16. Composição e Distribuição dos Cargos da CPI da Eletropaulo.

\begin{tabular}{|c|c|}
\hline TITULARES & PARTIDO \\
\hline Dep. Antônio Mentor (Presidente) & PT \\
\hline Dep. Jonas Donizete (vice Presidente) & PSB \\
\hline Dep. João Caramez (Relator) & PSDB \\
\hline Dep. José Augusto & PSDB \\
\hline Dep. Enio Tatto & PT \\
\hline Dep. Aldo Demarchi & DEM \\
\hline Dep. José Bittencourt & PDT \\
\hline Dep. Roque Barbieri & PTB \\
\hline Dep. Edson Giriboni & PV \\
\hline
\end{tabular}

Fonte: Elaboração do Autor

Os dados demonstram que o governo apresentou grande maioria com sete cadeiras na CPI contra apenas duas da oposição. Em relação aos cargos mais importantes, a presidência ficou com o deputado Antônio Mentor, do PT, e a base governista ficou com a vicepresidência, ocupando esse cargo o deputado Jonas Donizete, e a relatoria com o deputado João Caramez, do PSDB.

Em relação ao processo investigativo, notamos que todos os vinte e sete requerimentos foram aprovados, nos quais constava a convocação de testemunhas importantes, como ex-presidentes da Eletropaulo, o presidente da Eletropaulo na época e representantes das empresas envolvidas.

No final, a CPI chega à conclusão de que não houve nem um ato de ilegalidade no processo de privatização da Eletropaulo, como mostra o trecho do relatório aprovado: 
"De tudo quanto foi por nós analisado no decorrer dos trabalhos desta CPI, não foi possível constatar nenhuma ilegalidade no processo de privatização da Eletropaulo.

Tanto os atos de cisão da empresa, desenvolvidos de acordo com a legislação federal e estadual, como também o leilão de privatização, no qual apareceu apenas um concorrente, foram bem sucedidos.

Em que pese às ações da Eletropaulo terem sido alienadas pelo preço mínimo, motivo de grande surpresa para aqueles que a consideravam a joia da coroa, o Estado de São Paulo foi beneficiado com tal transação, fundamental para a sua recuperação fiscal e financeira que, somada às outras privatizações que ocorreram, permitiram a retomada de investimentos e o desenvolvimento do Estado. [...] Conforme foi muito bem demonstrado pelos depoentes ouvidos, todo o processo de privatização seguiu normas legais e técnicas, com participação e transparência, através dos conselhos administrativos, com a adoção das melhores práticas econômico-financeiras, dando-nos uma melhor compreensão, principalmente, sobre a avaliação da empresa e sobre a reversão dos bens para o Poder Concedente, ao término da concessão.

Se não por uma questão política, a falta de conhecimento mais aprofundado no assunto é a maior justificativa para a impetração das ações populares contra a privatização da Eletropaulo que tomamos conhecimento, as quais se fundamentaram em uma premissa errônea, ou seja, de que a avaliação da empresa pelo método do fluxo de caixa descontado é ilegal”. (Relatório da CPI da Eletropaulo: Pag. 50).

\section{Quadro 17. Parecer dos Deputados Estaduais sobre Relatório Final da CPI da}

Eletropaulo.

\begin{tabular}{|c|c|c|}
\hline DEPUTADOS & PARTIDO & VOTO \\
\hline Dep. Edson Giriboni & PV & Favorável \\
\hline Dep. Jonas Donizete & PSB & Favorável \\
\hline Dep. João Caramez & PSDB & Favorável \\
\hline Dep. José Augusto & PSDB & Favorável \\
\hline Dep. Aldo Demarchi & DEM & Favorável \\
\hline Dep. Antônio Mentor & PT & Favorável \\
\hline Dep. Ênio Tatto & PT & Contrário \\
\hline Dep. José Bitencourt & PDT & Contrário \\
\hline Dep. Roque Barbieri & PTB & Contrário \\
\hline
\end{tabular}

Fonte: Elaboração do Autor

Notamos que, do total de nove deputados titulares da comissão, seis votaram de forma favorável ao relatório, dentre eles o deputado da oposição que deteve na CPI o cargo de presidente. Na análise do relatório final, pudemos acompanhar que as conclusões e o 
andamento do processo investigativo foram minuciosos e corresponderam aos objetivos postos de investigar a venda da Eletropaulo, uma vez que várias autoridades foram convocadas. Todos os requerimentos de informação foram aprovados, e o presidente da CPI, membro da oposição, não sofreu maiores constrangimentos oficiais por estar na posição de coordenador dos trabalhos.

\subsection{Distrito Federal}

No período analisado, o Distrito Federal foi governado por José Roberto Arruda, do Democratas (DEM), e mantinha uma coalizão de governo composta por treze partidos: DEM, PR, PPS, PMN, PP, PR, PMDB, PTB, PSDB, PRP, PSC, PSB, PP, tendo como oposição o PT. Na Legislatura 2007- 2010, o governador construiu uma coalizão governista com 79,2\% dos deputados da Câmara Distrital.

\section{a) CPI da Gautama}

A CPI da Gautama foi instalada em 2007, através do requerimento 350/2007, de Berinaldo Pontes (PP), com o objetivo de investigar os contratos firmados entre o Governo do Distrito Federal e a construtora Gautama, no período 2000 a 2007. Além disso, propunha-se a investigar outras possíveis condutas ilícitas de agentes públicos, bem como pessoas físicas e jurídicas, alvos das investigações promovidas pela "Operação Navalha” da Polícia Federal.

Quadro 18. Composição e Distribuição dos Cargos da CPI da Gautama.

\begin{tabular}{|c|c|}
\hline DEPUTADOS & PARTIDO \\
\hline Dep. Bispo Renato (Presidente) & PR \\
\hline Dep. Jaqueline Roriz (Vice - Presidente) & PMN \\
\hline Dep. Junior Brunelli (Relator) & PSC \\
\hline Dep. Aylton Gomes & PR \\
\hline Dep. Cabo Patrício & PT \\
\hline
\end{tabular}

Fonte: Elaboração do Autor 
A base governista teve grande maioria na comissão: de um total de cinco deputados, quatro eram da base aliada do governo e um da oposição. No que se refere aos postos-chave, o governo detém o controle dos três cargos importantes: a presidência, ocupada pelo deputado Bispo Renato (PR), a vice-presidência, pela deputada Jaqueline Roriz (PMN), e a relatoria ficou com o deputado Junior Brunelli (PSC).

A instalação da CPI só se legitimou após as investigações, com apresentações de evidências por três instituições de controle do sistema político brasileiro: o Tribunal de Contas da União (TCU), a Controladoria Geral da União (CGU) e o Tribunal de Contas do Distrito Federal, sobre o contrato entre a Gautama e a Secretaria de Estado de Agricultura, Pecuária e Abastecimento do Distrito Federal. O contrato consistiu na execução de estudos complementares de impacto ambiental sobre áreas irrigáveis da bacia do Rio Preto, no valor aproximado de cento e quarenta milhões de reais. A CPI procedeu com amplo trabalho investigativo, incluindo visitas e estudos técnicos e periciais sobre os impactos sociais, ambientais e econômicos do contrato da obra. A grande maioria dos requerimentos foi aprovada, incluindo os que exigiam a quebra do sigilo bancário das pessoas envolvidas.

Primeiramente, as conclusões da CPI são contundentes, elas vão desde o nível técnico ao nível criminal, concluindo que as obras de irrigação da bacia do Rio Preto não tiveram todos os estudos técnicos necessários para mensurar seus efeitos sociais, ambientais e econômicos. A comissão chegou à conclusão de que houve várias irregularidades, como superfaturamento dos contratos, fraude do processo licitatório e manutenção da empresa responsável em executar as obras após expiração do tempo contratual. O relatório da CPI, transcrito abaixo, defendeu a

“... existência de uma organização criminosa com atuação na execução de obras públicas que também atingiu o Distrito Federal se utilizando de agentes políticos e funcionários da Secretaria de Agricultura, Pecuária e Abastecimento" (Relatório Final da CPI da Gautama. Pag. 241)".

A CPI elaborou recomendações a várias outras instituições, como à Polícia Federal, para instauração de inquéritos sobre os envolvidos; ao TCE e ao CGU, para as sanções administrativas dos acusados; à Polícia Civil, para abertura de inquérito; e ao Ministério Público, recomendações a fim de que essa instituição aprofundasse as investigações, responsabilizando, civil e criminalmente, os acusados. 
Notamos, portanto, nesta CPI que, apesar de o governo ter total controle sobre ela, através de uma grande maioria de assentos nela e da ocupação dos postos-chave, o processo investigativo ocorreu conforme exige a Constituição, com análise de vários documentos, depoimentos de pessoas importantes e com conclusões e recomendações às outras instituições de controle, que, como pode ser observado, foram contundentes.

\section{b) CPI dos Cemitérios}

A CPI dos Cemitérios foi instalada em 2008, devido ao requerimento 614/2007 do deputado Reguffe (PDT), e teve como objetivo investigar as possíveis violações aos direitos humanos e as inúmeras irregularidades de improbidade administrativa praticadas pela empresa Campos da Esperança Serviços Ltda., responsável pela administração dos cemitérios do cemitérios no Distrito Federal. Segue, abaixo, a composição da CPI:

\section{Quadro 19. Composição e Distribuição dos Cargos da CPI dos Cemitérios.}

\begin{tabular}{|c|c|}
\hline TITULARES & PARTIDO \\
\hline Dep. Rogério Ulysses (Presidente) & PSB \\
\hline Dep. Brunelli (Vice - Presidente) & PSC \\
\hline Dep. Benício Tavares (Relator) & PMDB \\
\hline Dep. Érika Kokai & PT \\
\hline Dep. Reguffe & PDT \\
\hline
\end{tabular}

Fonte: Elaboração do Autor

Notamos que o governo apresenta grande maioria na composição da CPI, quatro membros eram da base governista e um da oposição, em um total de cinco membros. A base governista controlou todos os cargos importantes, já que a presidência ficou com o deputado Rogério Ulysses, do PSB; a vice-presidência, com Brunelli, do PSC; e a relatoria, com Benício Tavares, do PMDB.

A CPI concluiu que a empresa investigada violou cláusulas do contrato de concessão ao identificar problemas como: má conservação dos cemitérios, não realização de obras de melhorias dos espaços, sonegação fiscal, exploração abusiva, com altos preços sobre os jazigos, subfaturamento da receita. Também concluiu que o governo do Distrito Federal, por 
meio da Secretaria do Estado de Desenvolvimento Social e Transferência de Renda, foi ineficaz negligente no controle dos serviços prestados pela empresa Campo da Esperança Serviços Ltda.

Com base nas conclusões e nos trabalhos de investigação, a CPI fez as devidas recomendações e acionou várias instituições. Ao Poder Executivo, foi recomendado: rompimento do contrato com a empresa em questão, atribuição de penalidades aos funcionários da Secretaria de Desenvolvimento Social e Transferência de Renda por negligência na instauração de fiscalização sistemática dos cemitérios etc. A comissão encaminhou ao Tribunal de Contas do Distrito Federal a verificação de danos ao Estado; à Polícia Civil determinou instaurar inquérito sobre os crimes praticados. Por fim, ao Ministério Público, recomendou a adoção de medidas necessárias de responsabilização civil e criminal dos envolvidos.

\subsection{Estado do Rio Grande do Sul}

No período analisado, o Rio Grande do Sul foi governado por Yeda Crusius, do Partido da Social Democracia Brasileira (PSDB), e mantinha uma coalizão de governo composta por seis partidos: PSDB, PPS, DEM, PP, PMDB, PTB, tendo três partidos de oposição, PT, PDT e PC do B. Na Legislatura 2007-2010, a governadora construiu uma coalizão governista com 74,2\% dos deputados da Assembleia Legislativa.

\section{a) CPI do DETRAN}

A CPI do DETRAN foi instalada em 2008, através da aprovação do requerimento 02/2007, que teve como objetivo investigar irregularidades presentes na autarquia, como: a) alto valor cobrado pelos exames práticos e teóricos; b) alto índice de reprovação desses exames; c) contratação de empresas privadas pelo DETRAN, com dispensa de licitação, para aplicação desses exames; d) o recebimento de benefícios dos servidores públicos do

DETRAN por parte dessas empresas privadas; e) desvios de dinheiro públicos através desses contratos; f) irregularidades no contrato com empresas privadas em serviços de 
remoção, depósito e guarda de veículos etc. Essa comissão teve como objetivo investigar um período de doze anos, que vai de 1996 a 2008, ou seja, quatro mandatos de governador do estado. Essa CPI apresentou a seguinte composição e distribuição dos cargos-chaves:

\section{Quadro 20. Composição e Distribuição dos Cargos da CPI do DETRAN}

\begin{tabular}{|c|c|}
\hline TITULARES & PARTIDO \\
\hline Dep. Fabiano Pereira (Presidente) & PT \\
\hline Dep. Paulo Azeredo (Vice - Presidente) & PDT \\
\hline Dep. Adilson Troca (Relator) & PSDB \\
\hline Dep. Stela Faria & PT \\
\hline Dep. Marco Peixoto & PP \\
\hline Dep. WestPhalen & PP \\
\hline Dep Alexandre Postal & PMDB \\
\hline Dep. Gilberto Capoani & PMDB \\
\hline Dep. Gerson Burmann & PDT \\
\hline Dep. Cássia Carpes & PTB \\
\hline Dep. Carlos Gomes & PPS \\
\hline Dep. Marquinho Lang & DEM \\
\hline
\end{tabular}

Fonte: Elaboração do Autor

Notamos, na tabela acima, que, de um total de doze deputados com assento na CPI, oito faziam parte da base do governo e quatro eram da oposição. Em relação aos cargos mais importantes, a base do governo ficou com a relatoria, cargo ocupado pelo deputado Adilson Troca, do PSDB; e o cargo de presidente ficou com a oposição, ocupado pelo deputado Fabiano Pereira, do PT. Assim, notamos que o governo teve uma grande maioria na comissão, mas não deteve o controle total dos principais cargos da CPI.

A CPI rejeitou requerimentos de informação da oposição com conteúdo de substancial importância para o aprofundamento de seus trabalhos investigativos, como documentos e escutas da Polícia Federal relacionados à operação RODIN, a convocação de ex-presidentes do DETRAN, a avaliação de imóveis da governadora do Rio Grande do Sul etc. Após todo o trabalho de investigação, essa CPI concluiu que existia um esquema de desvio de recursos públicos do DETRAN, baseado no superfaturamento dos preços. A CPI chegou, também, à conclusão de que houve participação de partidos e governos nesse 
esquema de corrupção. O relatório final fez várias recomendações e encaminhamentos a outras instituições responsáveis pela responsabilização e julgamento, bem como à Polícia Federal e ao Ministério Público.

No entanto, é interessante notar que as recomendações da bancada do PT foram feitas em separado e contestaram a decisão do relator. Em seu voto, a bancada do PT afirmou que a conclusão contida no relatório final da CPI sobre a não participação de partidos e governos no esquema de corrupção vai contra a conclusão de outras instituições fiscalizadoras, como Ministério Público Estadual e Federal, Controladoria Geral do Estado, Polícia Federal e Poder Judiciário Federal.

Portanto, verifica-se, ao longo dos trabalhos da CPI, que se procurou evitar a investigação de elementos políticos, como partidos e governo ${ }^{19}$, mesmo com provas obtidas por outros órgãos fiscalizadores, como mostram as escutas da Polícia Federal, que pessoas ligadas à cúpula do Governo de Yeda Crusius, como o vice-governador, o chefe da Casa Civil, o presidente do Detran, aparecem em gravações telefônicas tratando de assuntos relacionados às fraudes do DETRAN.

\section{b) CPI da Corrupção}

A CPI da corrupção foi instalada no ano de 2009, através do requerimento 1/2009 de autoria da deputada Stella Farias, da oposição (PT), e de mais 39 parlamentares, com o objetivo de investigar a existência de uma grande rede de corrupção envolvendo agentes públicos do estado do Rio Grande do Sul, com foco em determinados tipos de crimes, como: lavagem de dinheiro, ocultação de bens, corrupção ativa e passiva, formação de quadrilha, crime contra a lei de licitações envolvendo Secretaria de Irrigação e Assuntos Múltiplos de Água, Secretaria de Obras Públicas, todos investigados pela "Operação Solidária", da Polícia Federal. A CPI apresentou a seguinte composição e distribuição dos postos-chave:

\footnotetext{
19 Esta CPI apenas indiciou 40 elementos que já vinham respondendo processos na justiça e isentou exsecretários, presidentes da autarquia (aqui entendidos como elementos políticos).
} 
Quadro 21. Composição e Distribuição dos Cargos na CPI da Corrupção

\begin{tabular}{|c|c|}
\hline TITULARES & PARTIDO \\
\hline Stella Farias (Presidente) & PT \\
\hline Gilberto Capoani (Vice - Presidente) & PMDB \\
\hline Coffy Rodrigues (Relator) & PSDB \\
\hline Daniel Bordgnon & PT \\
\hline Sandro Boka & PMDB \\
\hline João Fischer & PP \\
\hline Pedro Westphalen & PP \\
\hline Adilson Troca & PSDB \\
\hline Gilmar Sossella & PDT \\
\hline Iradir Pietroski & PTB \\
\hline Paulo Borges & DEM \\
\hline Luciano Azevedo & PPS \\
\hline
\end{tabular}

Fonte: Elaboração do Autor

A base governista ocupou a grande maioria das doze cadeiras da Comissão, nove deputados pertenciam à base do governo e apenas três eram da oposição. Em relação aos postos-chave, a presidência ficou com a oposição, cargo ocupado pela deputada Stella Farias, do PT; em contrapartida, a base do governo ficou com a relatoria, ocupada pelo deputado Coffy Rodrigues, do PSDB, e a vice-presidência, com o deputado Gilberto Capoani, do PMDB.

Durante os trabalhos investigativos, foram analisados materiais coletados por vários órgãos fiscalizadores, como Polícia Federal, Ministério Público Federal e Estadual, Controladoria Geral Estadual e etc., que apontavam ligações de agentes políticos do alto escalão do Governo de Yeda Crusius com as irregularidades que vinham ocorrendo no estado.

A CPI da corrupção, no que tange à relação governo x oposição, viveu uma situação conflituosa. Foram elaborados dois relatórios finais, um do relator e outro das bancadas do PT, PC do B, PDT e DEM. No seu relatório, o relator procura demonstrar que a presidente da CPI, da oposição, desrespeitou o Regimento Interno da Casa, tomando decisões unilaterais, como convocação ou envio de convite a pessoas para depor, quebra de sigilo telefônico e bancário sem a votação do Plenário da CPI. Além disso, o relatório concluiu que não houve provas suficientes que ligassem, de maneira efetiva, os membros da administração estadual às 
irregularidades administrativas veiculadas pelos outros órgãos de fiscalização e controle. Por fim, o relatório final, assinado por um membro da bancada governista, conclui, isentando a governadora e seus pares, do suposto superfaturamento em obras públicas.

Entretanto, como salientado acima, foi elaborado um relatório alternativo ao do relator, visando acentuar discordâncias do relatório oficial, como aponta o trecho abaixo elaborado pelas bancadas do PT, PC do B, PDT e DEMN:

\begin{abstract}
"Nossas conclusões, aqui delineadas, estão baseadas no conjunto de provas produzidas durante os trabalhos da comissão, que nos permitiram estar convictos da existência de operadores privados, empreiteiros e lobistas que, para perpetrar o direcionamento de licitações e contratos, contavam com a proteção e o auxílio remunerados de agentes políticos de grande influência em nosso Estado, utilizados para o enriquecimento ilícito dos mesmos e para financiamento de campanhas eleitorais e estruturas partidárias. Assim, por não concordar de forma alguma com o relatório apresentado pelo Dep. Coffy Rodrigues, que não apurou os fatos determinados da CPI, viemos apresentar na forma do Art. 140, $\S 1^{\circ}$ do Regimento Interno da AL, esta Declaração de Voto Contrário". (Relatório Final da CPI da Corrupção, Pag. 104).
\end{abstract}

Considerando o argumento de que o Ministério Público tinha obtido documentos e gravações telefônicas que traduziam, em provas contundentes, a participação de diversos assessores próximos à governadora nos esquemas de recebimento e distribuição de propina, principalmente para fraudes de licitação, observamos pontos importantes que indicariam uma possível tentativa do governo de influenciar os trabalhos da CPI. Em seu relatório alternativo, a oposição, liderada pelo PT, pediu indiciamento de 32 pessoas (governadora, membros do alto escalão, ex-secretários) por improbidade administrativa.

O relatório final "alternativo" destaca a denúncia de irregularidade na composição da CPI. Como consta do Regimento Interno da Casa, a CPI deve ser composta levando em conta a proporcionalidade dos partidos no Plenário, o que não aconteceu. Tanto PSDB como PDT apresentavam o mesmo número de cadeiras no Legislativo, não justificando o fato de o PSDB ter duas cadeiras na comissão e o PDT apenas uma. Além disso, o relator da CPI teria vínculos com as fraudes que estavam sendo investigadas, como apontaram as provas da “Operação Solidária” e Rodin da Polícia Federal

Os membros da base governista faltaram às sessões que iriam votar os requerimentos importantes para o aprofundamento das investigações, como, por exemplo: 
requerimento para a convocação de testemunhas ligadas ao governo e sob suspeita de irregularidade, requisição de documentos que provavam o envolvimento de agentes políticos do alto escalão do governo de Yeda Crusius. Esses fatores tornaram as investigações da CPI superficiais, as convocações de testemunhas foram poucas e nem todos os documentos foram analisados pela comissão.

A conclusão do relatório alternativo confeccionado pela oposição, capitaneada pelo PT, afirmou que a CPI não cumpriu seu papel constitucional e que o governo influenciou, diretamente, as decisões da Comissão, blindando os agentes políticos ligados ao governo de Yeda Crusius, protegendo, inclusive, a própria figura da governadora, visando evitar danos à imagem de seu governo e, consequentemente, prejuízos ao capital político do PSDB, no estado do Rio Grande do Sul.

Nessa CPI, fica clara a lógica da maioria e da minoria e do governo x oposição, em conflito político no interior da Comissão. A base governista buscou blindar-se, visando minimizar um escândalo político de grandes proporções, e a oposição procurou, exaustivamente, repercutir essas denúncias objetivando causar um grande escândalo político. Outro elemento importante no desenvolvimento desse processo político corresponde ao comportamento do DEM: o partido pertencia à base governista. No entanto, com o aparecimento de denúncias contundentes contra o Governo, assumiu, claramente, postura oposicionista. O custo político por se manter ao lado do governo supera os custos de se colocar contra ela. Assim, a estratégia mais racional foi caminhar no sentido de se posicionar contra o governo, evitando desgastes políticos.

\section{c) CPI do Polo dos Pedágios}

Essa CPI foi instalada em 2007, pela aprovação do Requerimento 01/2007, de autoria de vinte deputados, como o objetivo de investigar os contratos de concessão entre os DAERS/RS e as empresas concessionárias responsáveis pela administração e manutenção das rodovias do estado do Rio Grande do Sul. A CPI apresentou a seguinte composição e distribuição dos cargos mais relevantes: 


\section{Quadro 22. Composição e distribuição dos cargos na CPI do Polo dos Pedágios.}

\begin{tabular}{|c|c|}
\hline TITULARES & PARTIDO \\
\hline Gilmar Sossela (Presidente) & PDT \\
\hline Paulo Borges (Vice - Presidente) & DEM \\
\hline Belfran Rosado (Relator) & PPS \\
\hline Dionilso Marcon & PT \\
\hline Marisa Formolo & PT \\
\hline Alceu Moreira & PMDB \\
\hline Edson Brum & PMDB \\
\hline Francisco Appio & PP \\
\hline Marco Peixoto & PP \\
\hline Paulo Azeredo & PDT \\
\hline Paulo Brum & PSDB \\
\hline Iradir Pietroski & PTB \\
\hline
\end{tabular}

Fonte: Elaboração do Autor

O quadro acima mostra que, de doze deputados titulares da CPI, oito eram da base do governo e quatro da oposição. Em relação aos postos-chave, notamos que a base governista não controlou todos, já que o cargo de presidente ficou com o deputado Gilmar Sossela, do PDT; entretanto, a vice-presidência ficou com o deputado Paulo Borges, do DEM, e a relatoria, com o deputado Belfran Rosado, do PPS, ambos membros da bancada governista.

Analisando o que estava sendo feito no decorrer dos trabalhos da CPI, notamos uma Comissão relativamente despolitizada, apegada aos termos técnicos do problema da concessão à iniciativa privada, detalhando a obrigação das concessionárias, das burocracias estaduais, dos valores a serem cobrados etc. Não obstante, notamos que os convocados a depor tinham, todos, ligação com o setor privado, mas todos os requerimentos referentes à convocação deles foram aprovados. Foram realizadas sessões de consultoria para tirar dúvidas sobre a lógica de funcionamento do modelo de concessão gaúcho.

Em relação às conclusões do relator, observamos um relatório com recomendações às burocracias, como os DAERS e AGERGS, para maior eficiência na execução de políticas de transporte, em relação ao primeiro, e melhor fiscalização, em relação ao segundo. Elaborou recomendações às concessionárias para serem mais transparentes em relação aos critérios referentes aos valores cobrados nos polos dos pedágios; e, por fim, recomendou ao Tribunal 
de Contas do Estado que acompanhasse a execução dessas recomendações por parte das instituições citadas.

\subsection{Estado de Mato Grosso}

No período analisado, o estado do Mato Grosso foi governado por André Puccinelli, do Partido do Movimento Democrático Brasileiro (PMDB), e mantinha uma coalizão de governo composta por oito partidos: PMDB, PPS, PSB, PL, PP, PDT, PT, PR, com dois partidos de oposição, o PSDB e o DEM. Na Legislatura 2007-2010, o governador construiu uma coalizão governista com 70,7\% dos deputados da Assembleia Legislativa.

\section{a) CPI da Secretaria do Estado de Meio Ambiente (SEMA)}

Essa CPI foi instalada em 2007, através da aprovação do requerimento 154/207, de autoria de várias lideranças partidárias, e teve, como pano de fundo, as denúncias realizadas pelo IBAMA, Polícia Federal, Ministério Público Federal e Poder Judiciário Estadual. Denominada de "Operação Guilhotina", foi responsável pela prisão, lacre e paralisação de empreendimentos sob a acusação de crimes ambientais. Essa CPI visou investigar supostas irregularidades na SEMA (Secretaria Estadual de Meio Ambiente de Goiás), em relação às licenças expedidas pelo órgão, às queimadas irregulares ocorridas nos últimos dez anos, aos desmatamentos sem autorização, ao comércio de madeira ilegal etc. A CPI apresentou a seguinte composição:

\section{Quadro 23. Composição e Distribuição dos Cargos na CPI da SEMA}

\begin{tabular}{|c|c|}
\hline TITULARES & PARTIDO \\
\hline Dep. José Riva (Presidente) & PP \\
\hline Dep. Walter Rabello (Vice-Presidente) & PP \\
\hline Dep. Dirceu Dal'Bosco (Relator) & DEM \\
\hline Dep. Carlos Avalone & PSDB \\
\hline Dep. Mauro Savi & PR \\
\hline
\end{tabular}

Fonte: Elaboração do Autor 
A base governista apresentou maioria na CPI, entre os titulares, ficou com três cadeiras contra duas da oposição; no que tange aos cargos principais, o governo controlou dois importantes deles: o de presidente, ocupado pelo deputado José Riva, do PP e a vicepresidência, ocupada pelo deputado Walter Rabello, do PP; em contrapartida, o cargo de relator ficou com a oposição, ocupado pelo deputado Dirceu Dal'Bosco, do DEM.

Em relação aos trabalhos investigativos, observamos, pelo relatório final, que as investigações realizadas pela CPI foram bastante pormenorizadas, analisando todos os empreendimentos, pessoas físicas e jurídicas denunciados pela "Operação Guilhotina" da Polícia Federal. A CPI também realizou investigação analítica ampla sobre a organização administrativa da SEMA, procurando compreender sua estrutura burocrática e seus servidores e respectivas funções dentro da instituição. Para tanto, a Comissão se utilizou de vasta documentação, de oitivas de testemunhas de acusados e de especialistas.

Nas conclusões, predominou o tom crítico, como ocorrera no relatório todo apresentado pelo relator afirmando que a SEMA apresenta uma gestão administrativa obsoleta, em que existe grande capital humano que é subutilizado por uma estrutura centralizadora, altamente burocrática e ineficiente. O relator conclui que é exatamente por esse tipo de modelo de gestão que essa instituição não consegue desempenhar seu papel de fiscalização e monitoramento, que envolve questões ambientais - queimadas, desmatamentos, empreendimentos irregulares etc. - no estado do Mato Grosso.

Nos encaminhamentos, o relator recomenda ao Poder Executivo que realize uma reforma administrativa na SEMA, a fim de torná-la mais eficiente e econômica, através de um processo de reformulação de suas burocracias e regimentos. Observamos, portanto, na dinâmica desenvolvida pela CPI que ela cumpriu seu papel constitucional de investigação do Poder Executivo, ficando distante dos interesses dele e procurando se colocar à margem do conflito desenvolvido pelas forças partidárias em disputa no estado. 


\subsection{Considerações Finais}

Antes de discorrer sobre as considerações finais acerca das CPIs acima descritas e analisadas, vale ressaltar que as afirmações nesta seção estão baseadas nos relatórios finais emitidos pelas comissões de inquérito em questão. Qualquer negociação de bastidor entre as lideranças políticas que não constam na cena política não será considerada, porque, claramente, a pesquisa não teve contato com esse tipo de informação.

Em relação à lógica das CPIs, de início, podemos afirmar que, no que diz respeito ao controle dos postos-chave, no total de onze relatórios analisados, em cinco, a base governista deteve os dois principais cargos - presidência e relatoria -, e nas onze CPIs, ou o cargo de presidente ou relator ficou com a base governista. Outro ponto relevante é que a autoria dos requerimentos para instalação de CPIs sempre partiu de membros da oposição.

Não obstante, o importante a salientar é o padrão de funcionamento detectado durante a análise da dinâmica desenvolvida nas CPIs. O que se observa nas comissões de inquérito instaladas em todos os estados estudados é que, se o foco investigativo da CPI se encontra na periferia do poder executivo ${ }^{20}$, como em funcionários de baixo escalão, em autarquias de baixa visibilidade pública etc., ou quando a investigação refere-se a vários mandatos de governador e não sobre o atual, os trabalhos investigativos da CPI ocorrem normalmente. $\mathrm{O}$ custo por influenciar o decision making é maior do que aquele em deixar a CPI ter discricionariedade. No entanto, quando o foco investigativo da CPI é dirigido ao centro do poder Executivo $^{21}$, a maioria governista controla as decisões da Comissão, objetivando blindar o governo de um possível escândalo, com efeitos negativos para os interesses coletivos da coalizão governista e para o Executivo Estadual.

No primeiro caso, estão as seguintes CPIs: CELG, Endividamento, da SEMA, Eletropaulo, Cemitérios, Gautama e Polo dos Pedágios; nesses exemplos, a CPI teve discricionariedade e cumpriu sua função constitucional de controle sobre o Executivo. No segundo caso, temos o exemplo da CDHU, em São Paulo, do DETRAN e da Corrupção, no Rio Grande do Sul, e da Saúde, em Goiás, em que a coalizão governista controlou as decisões

\footnotetext{
${ }^{20}$ Aquele tipo de irregularidade que não se tornará um escândalo político com proporções capazes de arranhar a imagem do Executivo e, por conseguinte, o capital político do governador e seus aliados no Legislativo.

${ }^{21}$ Aqueles casos em que nas denúncias estão envolvidos o alto escalão do governo, ou, até mesmo diretamente a figura do governador.
} 
da CPI para blindar o Executivo Estadual e a própria coalizão legislativa de possíveis escândalos, crises e responsabilizações.

No caso das CPIs, existe uma variável interveniente no cálculo do custo/ benefício do ator: a percepção da sociedade através do que a literatura chamou de "alarmes de incêndio", ou seja, o deputado leva em conta a percepção e a possível pressão da opinião pública contra o governo. No caso do deputado pertencente à coalizão governista, a opção de permanecer fiel ao governo pode gerar custos maiores de ação, já a possibilidade de se mover em direção aos anseios da opinião pública pode se transformar em capital político no futuro. Portanto, a manutenção da participação incondicional na coalizão governista tem alguns limites, sendo o principal as fortes pressões externas da opinião pública. No entanto, os alarmes de incêndio estaduais poucas vezes foram acionados. Constatamos ocorrência desse fenômeno apenas no Rio Grande do Sul, quando o DEM (Democratas) deixou a base da governadora Yeda Crusius (PSDB) e deu suporte para o desenvolvimento da CPI da Corrupção na Assembleia estadual - a ruptura do partido da base com a governadora ocorreu no ápice da crise política no Rio Grande do Sul.

Outro elemento que apresenta regularidade nas CPIs é a proposição do tema (sua origem e natureza) ou fato investigado pela comissão. Quando o foco da investigação da CPI corresponde a fatos diretamente ligados ao que chamamos de centro do Poder Executivo, a investigação não é de origem primária dos próprios parlamentares, mas, sim, motivada por ações de Polícia Federal, Ministério Público e outros órgãos, responsáveis por colocar o tema na agenda social e política, atraindo a atenção pública e tornando mais racional para os atores políticos legislativos a instalação de uma CPI. Como, por exemplo, no caso da CPI do DETRAN ${ }^{22}$, da Corrupção no Rio Grande do $\mathrm{Sul}^{23}$, da $\mathrm{CDHU}^{24}$ em São Paulo e da Saúde ${ }^{25}$, em Goiás.

Podemos concluir que as CPIs funcionam como mecanismos de accountability quando o centro do Poder Executivo não está sob ameaça, ou quando os "alarmes de incêndio" já foram acionados por outras instituições, tornando a oposição mais capaz de iniciar o inquérito. Nos demais casos, o Executivo influencia as decisões da CPI pelo domínio

\footnotetext{
${ }^{22}$ Investigações iniciadas pela "Operação RODIM da Polícia Federal”.

${ }^{23}$ Investigação iniciada pela "Operação Solidária e RODIN” da Polícia Federal.

${ }^{24}$ Investigações iniciadas pela Polícia Civil e pelo Ministério Público Estadual, divulgadas pelo Jornal Folha de São Paulo.

${ }^{25}$ Relatórios do TCE apontavam descumprimento das regras do orçamento estadual.
} 
que tem sobre coalizão majoritária e, consequentemente, blinda-se contra as estratégias da oposição. 


\section{CONCLUSÃO}

O mainstream da ciência política brasileira produziu explicações consistentes no que se refere ao funcionamento de nossa democracia. Os mecanismos de governabilidade e o processo decisório do sistema político brasileiro encontram-se amplamente discutidos pela literatura,(...) sob a rubrica do presidencialismo de coalizão. Partimos da constatação consolidada da estabilidade e do funcionamento da democracia brasileira e, a partir disso, através de pergunta de pesquisa circunscrita, analisamos qual a natureza e a qualidade desse funcionamento, particularmente na dimensão de fiscalização e controle nos Legislativos estaduais.

Ao longo da pesquisa, tentamos demonstrar como a relação de cooperação, entre os legislativos e os executivos estaduais, influi na accountability horizontal em nível subnacional. Os dados demonstram que a formação de coalizões nas Assembleias Estaduais funciona como uma força centrípeta, atraindo um alto número de parlamentares para o apoio ao Executivo. Essa situação influi, diretamente, no desempenho do principal mecanismo de fiscalização à disposição do Legislativo, as Comissões Parlamentares de Inquérito. A principal pergunta que permeia o texto se refere aos incentivos que o deputado estadual possui para investigar o Executivo.

As prerrogativas dos parlamentares nos Legislativos Estaduais são pobres, do ponto de vista dos recursos institucionais, para produzir legislação relevante, restando pouco espaço para influir na produção legislativa do Executivo. Os recursos institucionais conferidos pela Constituição Federal determinam à União a competência privativa e abrangente em vinte e nove temas da administração pública, restando à arena estadual recursos muito restritos para legislar. Além disso, os recursos institucionais conferidos ao Executivo Estadual dotam-no de poder suficiente para dominar a proposição relevante na já restrita agenda legislativa na arena estadual. Os fortes recursos institucionais nas mãos dos governadores estaduais os tornam capazes de dominar o processo de proposições legislativas, independentemente do tamanho da bancada governista constituída. O tamanho da coalizão governista não impacta a independente força legislativa do governador, no entanto, impacta diretamente a dimensão de fiscalização e controle, já que é através da construção de amplas maiorias governistas que o Executivo Estadual pode constranger a instalação de uma CPI ou, ao menos, controlar a ocupação de cargos fundamentais (presidente e relator) da Comissão. 
As limitações dos recursos institucionais conferidos aos deputados estaduais geram problema para o incentivo no uso de suas prerrogativas de fiscalização e controle. $\mathrm{O}$ ato de fiscalizar o Executivo afasta os legisladores estaduais de conseguir os benefícios que perseguem (emendas ao orçamento, cargos em secretarias e autarquias). Ao adotar curso de ação cooperativa, o deputado estadual tem acesso a cargos e a emendas, o que, por si, aumenta a probabilidade de alcançar seu principal objetivo: reeleger-se ou progredir na carreira política elegendo-se prefeito ou deputado federal. No entanto, o curso de ação cooperativo (mais rentável aos deputados estaduais) exclui a possibilidade de exercer atividades de fiscalização e controle do Executivo estadual. Caso escolha controlar o Executivo em uma estratégia de não cooperação, o deputado estadual afasta-se dos benefícios distribuídos pelo Executivo. Portanto, o comportamento do deputado estadual ocorre em acordo com tal poder, porque esse comportamento é, racionalmente, mais rentável para manter e potencializar sua carreira política. ${ }^{26}$ Somente no caso das minorias oposicionistas, poderíamos esperar o incentivo racional à fiscalização com objetivo de enfraquecer o governo estadual com vistas a alcançar o posto na próxima eleição. ${ }^{27}$

Como vimos na dissertação, das 66 CPIs estaduais instaladas em 20 Assembleias na Legislatura 2007-2010, apenas 19,69\% tiveram como objetivo fiscalizar o Executivo estadual e ou suas secretarias. Os outros $80,30 \%$ das CPIs tiveram como objetivo fiscalizar temas diversos, sem qualquer ligação objetiva com o Executivo estadual. Além disso, o protagonismo dos membros da bancada governista nas CPIs instaladas nesses estados ocorre nos três atores/cargos principais nas Comissões Parlamentares de Inquérito, ou seja, a larga maioria dos postos estratégicos no interior dessas CPIs foi ocupada por parlamentares e partidos da base do governador. Destaque para o principal cargo que define o centro do processo decisório nas CPIs: membros das bancadas governistas ocuparam 83,33\% da presidência dessas Comissões.

Em qualquer democracia em que se consegue, efetivamente, estabelecer maioria legislativa, o controle do Legislativo sobre o Executivo vai mais perder do que ganhar. A questão central é se isso não deixa espaço para minorias atuarem efetivamente. De fato, os dados da dissertação mostram que existem muito poucas alternativas para as oposições nos

\footnotetext{
26 Assim como Andrade (1998), consideramos deputados estaduais atores racionais que, em contextos estratégicos, optam por ações que visam maximizar seus ganhos e minimizar suas perdas.

${ }^{27}$ Esse quadro corrobora os pressupostos da literatura que considera as Assembleias Legislativas e o cargo de Deputado Estadual como cargos de passagens, utilizados unicamente como canais de acesso às verbas do governador, como vias para progredir na carreira política.
} 
Estados da Federação. Da análise dos relatórios finais das CPIs, contidas na amostra do estudo, conseguimos identificar um padrão no desenvolvimento delas: nas Assembleias estaduais, elas funcionam como instrumento de accountability quando, o que chamamos de “centro do poder” Executivo, não está sob ameaça no objeto descrito do inquérito. Quando o objeto da investigação se desloca para o centro do Poder Executivo Estadual, a maioria governista controla os rumos da comissão a fim de blindar o Executivo Estadual e a própria coalizão governista de possíveis efeitos negativos.

A accountability é essencial para que a já funcional e estável democracia brasileira seja aperfeiçoada em sua qualidade. No caso do objeto de estudo aqui proposto, é essencial que o aperfeiçoamento institucional ocorra na estrutura de incentivo, produzida pelo desenho de nossas instituições políticas. A estrutura de incentivo gerada pelo desenho das instituições do Executivo e Legislativo estadual e, mais precisamente, os diferentes recursos institucionais (maiores, no caso do Executivo e menores, no caso do Legislativo) conferidos a esses atores, geram o trade off entre cooperação e controle. Tal configuração incentiva, via de regra, os deputados estaduais a adotarem um curso de ação que tem como marca a cooperação e a quase total ausência de controle em relação ao Executivo Estadual.

As evidências empíricas apresentadas no decorrer da dissertação nos mostram um cenário de forte déficit institucional na dimensão subnacional de nossa democracia. O déficit de fiscalização e controle dos legislativos subnacionais, em relação aos Executivos estaduais, afeta princípios essenciais da democracia, como, accountability, checks and balance e responsabilização, com impacto direto na eficácia e eficiência do funcionamento de nossas instituições. Além disso, tal déficit de fiscalização e controle impacta a dimensão vertical da accountability na medida em que diminuem as informações disponíveis para que eleitores possam fazer suas escolhas. Nos Estados, bem como na União, vemos, repetidamente, o sucesso e a solidez dos métodos e regras de nosso mecanismo eleitoral. No entanto, instituições como o poder Legislativo funcionam de maneira precária. A eficácia dos mecanismos de fiscalização e controle entre os poderes é a mais importante tarefa pendente no processo de aperfeiçoamento da qualidade da democracia brasileira. 


\section{BIBLIOGRAFIA}

ABRÚCIO, F. (1998). Os Barões da Federação. São Paulo, Hucitec/DCP-USP.

, F., TEIXEIRA, A. C. \& COSTA, M. F. (2001). "O Papel Institucional da Assembléia Legislativa Paulista: 1995 a 1998”. In: SANTOS, Fabiano (org.). O Poder Legislativo nos Estados: Diversidade e Convergência. Rio de Janeiro, Editora FGV.

AMORIM NETO, (1994), "Formação de Gabinetes Presidenciais no Brasil: coalizão versus cooptação". Revista Nova Economia, n. 1, vol. 4: 9-34.

AMORIM NETO, (2006). Presidencialismo e Governabilidade na Américas. FGV, São Paulo.

ANASTASIA, F. (2001). "Transformando o Legislativo: A experiência da Assembléia Legislativa de Minas Gerais”. In: SANTOS, Fabiano (org.). O Poder Legislativo nos Estados: Diversidade e Convergência. Rio de Janeiro, Editora FGV.

. ; MELO, C. R. \& SANTOS, F. (2004), Governabilidade e representação política na América do Sul. Rio de Janeiro/São Paulo, Fundação Konrad Adenauer/Fundação Unesp.

. ;CASTRO, M. M., \& NUNES, F. (2009). "Determinantes do Comportamento Particularista de Legisladores Estaduais Brasileiros”. In: Dados, vol. 52, no. 4, pp. 961-1001.

ANDRADE, R. C. (1998). "Processos Decisórios na Câmara dos Vereadores e na Assembléia Legislativa de São Paulo". In: (org.). Processo de Governo no Município e no Estado: uma Análise a Partir de São Paulo. São Paulo, Edusp.

CADAH.L.Q; CENTURIONE,D.;VASSELAI， F. (2011). "Controle Legislativo e Accountability no Brasil: As Comissões Parlamentares de Inquérito no Contexto do 
Presidencialismo de Coalizão.”. : II Fórum Brasileiro de Pós-Graduação em Ciência Política, São Carlos.

CERVI, E. U. (2009). "Produção Legislativa e Conexão Eleitoral na Assembleia Legislativa do Estado do Paraná”. In: Revista de Sociologia e Política, vol. 17, no. 32.

CLEMENTE, R. (2007). Variações de Presidencialismos na Federação Brasileira: Processo Político e Reforma nos Estados, 1995-2006. Tese de doutorado. Escola de Administração de Empresas de São Paulo, Faculdade Getúlio Vargas.

COLLIER, D. (1993), “The comparative method" in Finifter, Ada (ed) Political Science: the state of the discipline II. Washington, DC, APSA.

COSTA, Valeriano M. \& OLIVEIRA, Carlos T. (1998). "A Fraqueza da Assembléia Legislativa do Estado de São Paulo". In: ANDRADE, Régis (org). Processo de Governo no Município e no Estado: uma Análise a Partir de São Paulo. São Paulo, Edusp.

COUTO, C. G. (1998) Negociação, decisão e governo: padrões interativos na relação Executivo-Legislativo e o caso paulistano. In: Régis Stephan de Castro Andrade. (Org.). O Processo de governo no município e no Estado: uma análise a partir de São Paulo. São Paulo; Fapesp, v. , p. 41-72.

\& ABRÚCIO, F. (2003). "O Segundo Governo FHC: Coalizões, Agendas e Instituições". In: Tempo Social, vol. 15, no. 2, pp. 269-301.

DIAMOND, L. e MORLINO, L., (2005), Assessing the Quality of Democracy, The Johns Hopkins University Press, Baltimore: The Johns Hopkins University Press, 2005.

DOMINGUES, M. (2001). “Espírito Santo: Produção Legal e Relações entre os poderes Executivo e Legislativo entre 1995 e 1998”. In: SANTOS, Fabiano (org.). O Poder Legislativo nos Estados: Diversidade e Convergência. Rio de Janeiro, Editora FGV. 
FIGUEIREDO, A. (2001), "Instituições e Política no Controle do Executivo”. Dados, Vol. 44, n. 4, Rio de Janeiro.

. (2005), “As CPIs e a falta do que fazer”. Revista Inteligência, Julho.

e LIMONGI, F. (1999), Executivo e Legislativo na Nova Ordem

Constitucional. Fundação Getulio Vargas, Rio de Janeiro.

FONTES, J. (1994) A porta giratória. In: Folha de São Paulo, 03/02/1994, A3.

LEMOS, L. (2007), O controle Legislativo no Brasil pós 1988 - Instituições representativas no Brasil. Balanço e Reforma, UFMG, p. 37 - 54, Belo Horizonte.

LIMONGI, F. (2011) Entrevista: Não há espaço para uma terceira força nas disputas eleitorais. In: Folha Online, Disponível em: http://www1.folha.uol.com.br/poder/891480-naoha-espaco-para-uma-3-forca-nas-disputas-eleitorais-diz-limongi.shtml Acessado em 16/04/2011 Concedida a: Uirá Machado.

LIJPHART, A. (1971), Comparative Politics and the Comparative Method, American Political Science Review, 65, 682-693.

MADISON, J. (2003) O Federalista. Russel, Rio de Janeiro.

MANIN, B., PRZEWORSKI, A. e STOKES, S. (1999), "Elections and representation", in Adam Przeworski, Susan Stokes e Bernard Manin (eds.), Democracy, accountability and representation, Cambridge University Press, pp. 29-55.

MAINWARING, S. (1997). "Multipartism, Robust Federalism, and Presidentialism in Brazil”. In: \& SHUGART, Matthew (1997). Presidentialism and Democracy in Latin America. Cambridge, Cambridge University Press. 
(2001), Sistemas Partidários em Novas Democracias. O Caso do Brasil.

Porto Alegre / Rio de Janeiro, Mercado Aberto / Editora da FGV.

\& WELMA, C. (eds.). (2003), Democratic accountability in Latin America. Oxford University Press, Oxford.

KENNEY, Charles. (2003), "Horizontal Accountability: Concepts and Conflicts". In: Democratic accountability in Latin America. Oxford University Press, Oxford.

MELO, M.A. (2007), O vies majoritário na Política Comparada - Responsabilização, desenho institucional e qualidade democrática. In: RBCS, vol.22, n63, São Paulo.

MOISÉS, J.A. (2011), O Desempenho do Congresso Nacional no Presidencialismo de Coalizão (1995-2006) In: O Papel do Congresso Nacional do Presidencialismo Coalizão, Konrad Adenaeuer Stifung, Rio de Janeiro.

O'DONNELL, G. (1998), Accountability Horizontal e Novas Poliarquias, In: Lua Nova, ${ }^{\circ}$ 44, p. 27-54, São Paulo.

. (2003), "The Legal Institutionalization of Mistrust". In: Democratic accountability in Latin America. Oxford University Press, Oxford.

PEREIRA, A. R. (2001). "Sob a Ótica da Delegação: Governadores e Assembléias no Brasil Pós-1989”. In: SANTOS, Fabiano (org.). O Poder Legislativo nos Estados: Diversidade e Convergência. Rio de Janeiro, Editora FGV.

PEREIRA, C. \& MUELLER, B. (2000), “Uma Teoria da Preponderância do Poder Executivo. O Sistema de Comissões no Legislativo Brasileiro". Revista Brasileira de Ciências Sociais, n. 43, vol. 15: 45-67.

PEREIRA, V. (2010), “Comissão Parlamentar de Inquérito, Representação Proporcional e Minoria Parlamentar: Estudo de Caso”. E-Legis, n.5, Brasília. 
PRZEWORSKY, A. e TEUNE, H. (1970), The logic of comparative social inquiry. Malabr: Ney York, R. Krieger Pub. Company.

RICCI, P. \& TOMIO, F. (2010). Instituições e Decisões: Estudo Comparativo do Processo Legislativo nas Assembléias Estaduais. Paper apresentado no VII Encontro da Associação Brasileira de Ciência Política (ABCP), 2010, Recife.

. (2012). Seis décadas de processo legislativo estadual: processo decisório e relações Executivo/Legislativo nos Estados (1951-2010). In: Cardenos da Escola do Legislativo, Volume 13, numero 21, Belo Horizonte.

. (2013) O Poder da caneta. A medida provisória no processo legislativo estadual. Opinião Pública (UNICAMP. Impresso).

RIKER, W. H. The Theory of Political Coalitions. New Haven: Yale University Press, 1962.

SANTI, M. (2007) Criação de Comissões Parlamentares de Inquerito, Sergio Antônio Fabris Editor, Porto Alegre.

SANTOS, F. (2009) Como aperfeiçoar o sistema politico brasileiro? Ensaio de sugestão. In: O Sistema Político Brasileiro: continuidade ou reforma?, EDUFRO, pp.63-73, Rondônia. . (2001). "A Dinâmica Legislativa no Estado do Rio de Janeiro: Análise de uma Legislatura". In: (org.). O Poder Legislativo nos Estados: Diversidade $e$ Convergência. Rio de Janeiro, Editora FGV. - (2003), Poder Legislativo no Presidencialismo de Coalizão. UFMG, Belo Horizonte. 
SANTOS, F. (2009) Como aperfeiçoar o sistema politico brasileiro? Ensaio de sugestão. In: O Sistema Político Brasileiro: continuidade ou reforma?, EDUFRO, pp.63-73, Rondônia.

SNYDER, R. (2009) Reducción de la Escala: El Método Comparativo de Unidades Subnacionales. Revista Desarrolo Económico, Vol 49, No. 194, pp. 287-306.

SMUlOVITZ, C. \& PERUZZOTTI, H. (2000) Societal Accountability in Latin America. Journal of Democracy 11, 4: 147158.

TAYLOR, M. \& BURANELLI, V. (2007) "Ending up in Pizza: Accountability as a Problem of Institutional Arrangement in Brazil". Latin American Politics and Society, v. 49, p. 59-87.

WHITEHEAD, Laurence. (2000) "Institutional Design and Accountability in Latin America". Paper for Discussion at a conference at the Carter Center, Atlanta, October 16th -18th 2000.

\section{RELAÇÃO DOS RELATÓRIOS FINAIS DE CPIS.}

- Relatório Final dos trabalhos da Comissão Parlamentar de Inquérito sobre a CDHU no Estado de São Paulo;

- Relatório Final dos trabalhos da Comissão Parlamentar de Inquérito sobre a Eletropaulo no Estado de São Paulo;

- Relatório Final dos trabalhos da Comissão Parlamentar de Inquérito sobre Gautama no Distrito Federal;

- Relatório Final dos trabalhos da Comissão Parlamentar de Inquérito sobre irregularidades administrativas dos Cemitérios no Distrito Federal; 
- Relatório Final dos trabalhos da Comissão Parlamentar de Inquérito sobre os pedágios no Estado do Rio Grande do Sul;

- Relatório Final dos trabalhos da Comissão Parlamentar de Inquérito sobre o DETRAN no Estado do Rio Grande do Sul;

- Relatório Final dos trabalhos da Comissão Parlamentar de Inquérito sobre a Corrupção no Estado do Rio Grande do Sul;

- Relatório Final dos trabalhos da Comissão Parlamentar e Inquérito sobre a Secretaria de Meio Ambiente (SEMA) no Estado do Mato Grosso;

- Relatório Final dos trabalhos da Comissão Parlamentar de Inquérito sobre Sistema de Saúde Pública no Estado de Goiás;

- Relatório Final dos trabalhos da Comissão Parlamentar de Inquérito sobre as Causas do Endividamento do Estado de Goiás no período de 15.03.1991 a 31.12.2009;

- Relatório Final dos trabalhos da Comissão Parlamentar de Inquérito sobre Companhia de Energia Elétrica de Goiás (CELG). 